\title{
Assessment of Strategic Management Practices in Small Agribusiness Firms in Tanzania
}

\author{
Dissertation \\ to obtain the $\mathrm{Ph}$. D. degree \\ in the International Ph. D. Program for Agricultural Sciences in Goettingen (IPAG) \\ at the Faculty of Agricultural Sciences, \\ Georg-August-University Göttingen, Germany
}

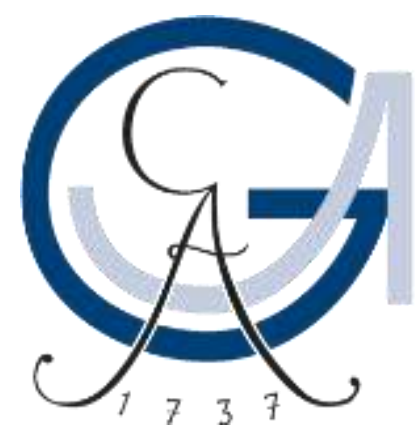

presented by

\section{Theresia Dominic}

born in Dar es Salaam (Tanzania)

Göttingen, May 2015 
D7

1. Referee: Prof. Dr. Ludwig Theuvsen

2. Referee: Prof. Dr. Achim Spiller

Date of dissertation: $21^{\text {st }}$ May 2015 


\section{Acknowledgements}

A number of people have assisted me in one way or another to complete my work successfully. To begin with, it gives me a great pleasure to acknowledge the support and help of my supervisor Prof. Dr. Ludwig Theuvsen, the Chair of Management in Agribusiness. He supported my research interest and allowed me work independently. His challenging comments have helped me to refine my work and grow intellectually as a researcher. Also, I would like to thank Prof. Dr. Achim Spiller and Prof. Dr. Oliver Musshoff for serving as my $\mathrm{PhD}$ committee members and keeping an open door for any queries.

My time at the University of Göttingen has been highly productive, working as a member of the GlobalFood research training group; a program under the Faculties of Agricultural Sciences and Economic Sciences. The program gave me opportunities to build a solid academic foundation and interact with fellow research associates from different countries, as well as research experts from different universities. In this case, I must thank the leadership and coordination team; Prof. Dr. Matin Qaim, J-Prof. Dr. Meike Wollni, Dr. Melanie Grosse and Diana Sieber. I would also like to thank members of the Chair of Management in Agribusiness for their support; Ms. Martina Reichmann, Dr. Anna Müller and Dr. Verena Otter; and the former members of the Chair, Dr. Maike Kayser and Dr. Matthias Heyder.

My studies would not have been possible without the joint financial support of the Ministry of Education and Vocational Training in Tanzania (MoEVT), the German Academic Exchange Service 'Der Deutsche Akademische Austausch Dienst' (DAAD), the German Research Foundation (DFG) and the Chair of Management in Agribusiness in the University of Göttingen. I appreciate the resources I received to be able to meet the living costs, travelling, field work and my participation in an international conference.

I would like to express my sincere gratitude to the agribusiness managers in Arusha, Dodoma and Tanga regions in Tanzania, who agreed to participate in the research survey. I would like to acknowledge the field work assistance I received from different people and their institutions in Tanzania. Special thanks to Mr. Mussa Mvungi (HomeVeg Tanzania Limited), Mr. Ray Ufunguo (Centre for Sustainable Development Initiative) and Ms. Gladness Foya (Small Industries and Development Organization). 
Others who served as enumerators are Ms. Getrude Kawau, Mr. Ephron M. Mtili, Ms. Lillian Mtani, Ms. Nuria Gulamali, Ms. Elizabeth Rwegasira, Mr. Halidini Sarakikya, Mr. Omari Kilo and Mr. Nicholaus Mhusa. Their hard work made the data collection process less challenging. I am grateful for the support I received from my employer, the University of Dar es Salaam (UDSM) in Tanzania. Special appreciation to Prof. Marcellina Chijoriga the former dean, Dr Ulingeta Mbamba, the current dean, and Dr Severine Kessy, the head of general management department; all from the UDSM Business School.

I would also like to thank my friends who have made the duration of my studies less stressful. Sigrid and Rudiger Pessel who invited me to their home, showed me a perfect example of the German culture, and made several arrangements to spend special social events, holidays and birthdays together. I truly appreciate everything they have done for me 'Danke sehr'. My current and former office mates in the GlobalFood program: Nico Herforth, De Zhou, Hanna Ihli, Hanna Freudenreich, Birgit Gassler, Christoph Steffen and Christine Kiria; for making the working atmosphere so friendly and enjoyable. Also, the dance club members in Goettingen, the Tanzanian students in Germany, and many more.

Most importantly, I am forever grateful for the unconditional love and support from my parents; Mr and Mrs Dominic Beda Massawe. There is no way I can thank them enough. I am also grateful to my sister Lydia Dominic Massawe 'Manka' who decided to reschedule her life plans to take care of my babies, so that I could pursue my studies successfully. Thank you sister!

Lastly, but not the least I would like to thank and honor my daughters; Tamica and Taraji, they have behaved very well during my absences. Their patience, politeness, home videos, phone conversations and funny letters encouraged me to keep going. I'm truly proud!

Theresia Dominic, Gottingen, March, 2015 


\section{Table of Contents}

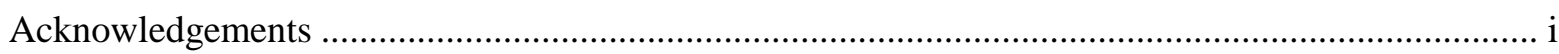

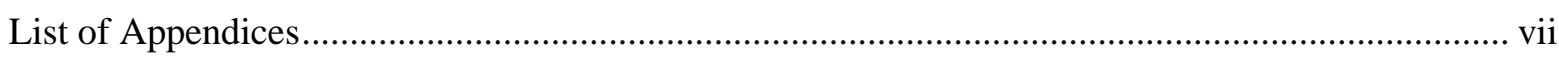

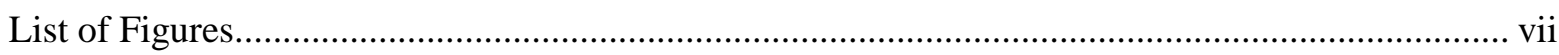

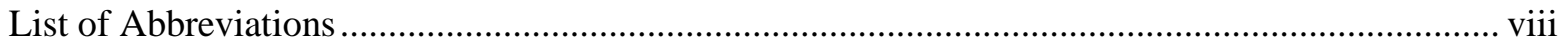

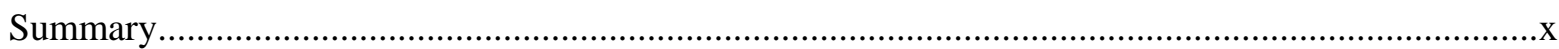

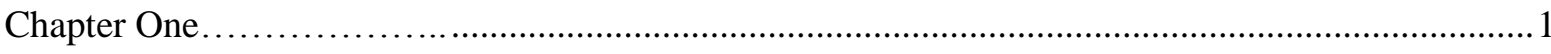

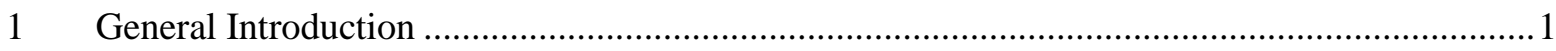

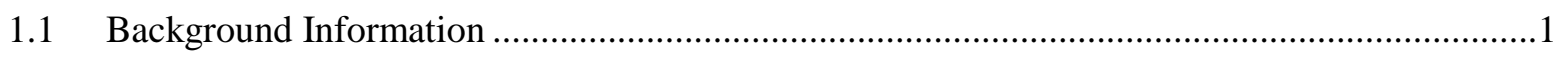

1.1.1 Role of Strategic Management and its Role on Attainment of Firm Objectives .........................1

1.1.2 Strategic Management in Small Agribusiness Firms in Developing Countries .........................2

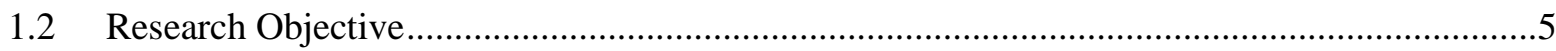

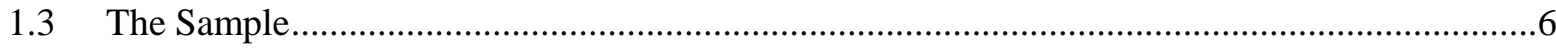

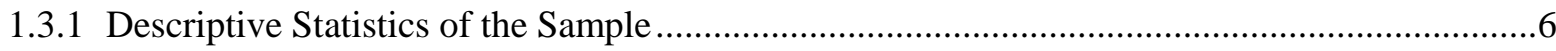

1.3.2 Status of Strategic Management (STM) Practices...................................................................

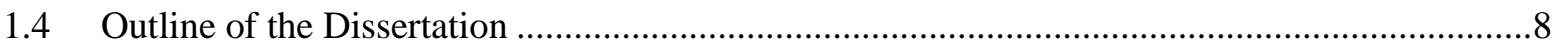

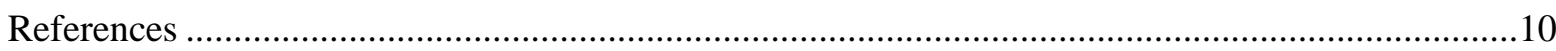

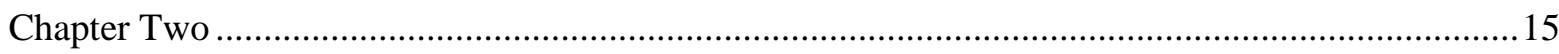

2 The Impact of External and Internal Factors on Strategic Management Practices of

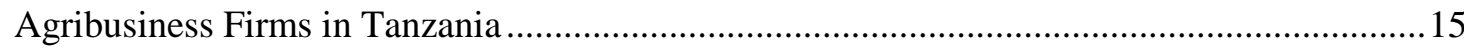

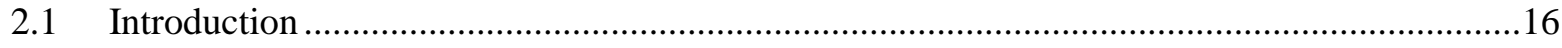

2.2 Theoretical Framework and Hypotheses …….......................................................................17

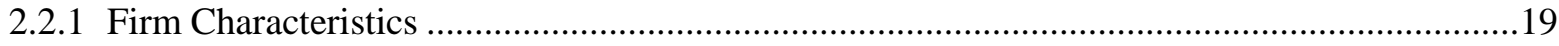

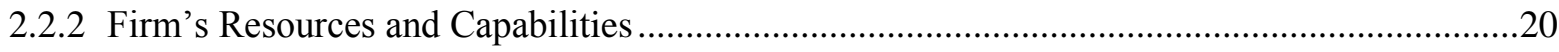

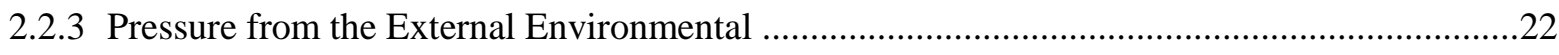

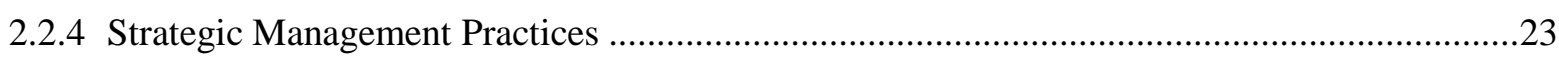

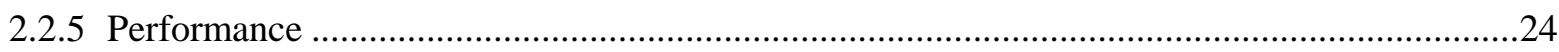

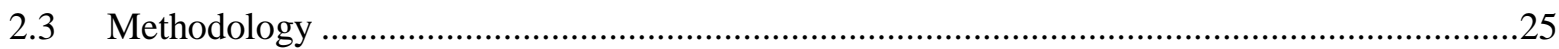

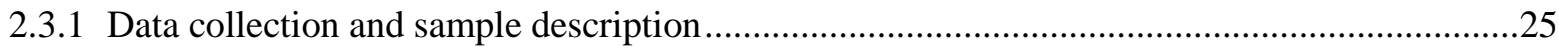

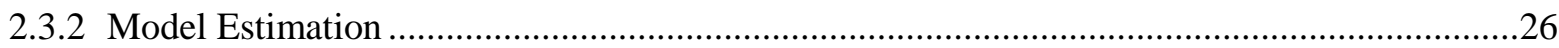

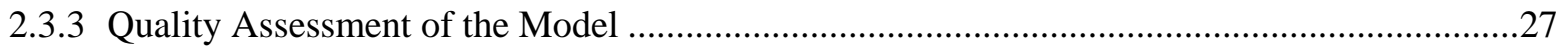

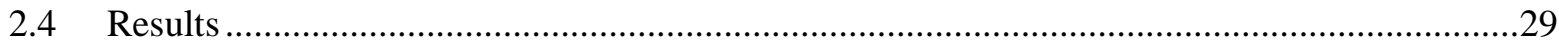

2.4.1 Importance-Performance Matrix Analysis (IPMA) for STM Practices.....................................31

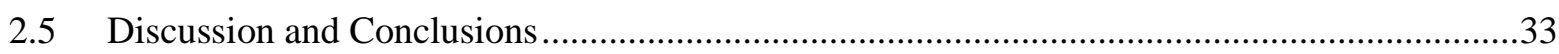


Chapter Three

3 Agribusiness Firm Resources and Performance: The Mediation Role of Strategic Management Practices .47

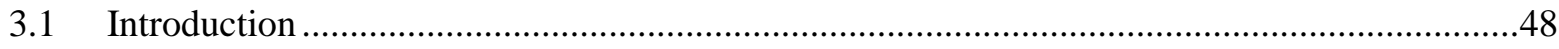

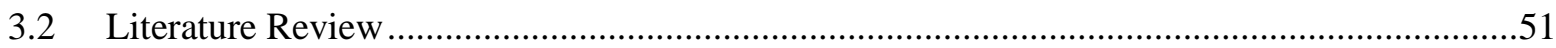

3.2.1 Role of Strategic Management Practices (STM) .................................................................

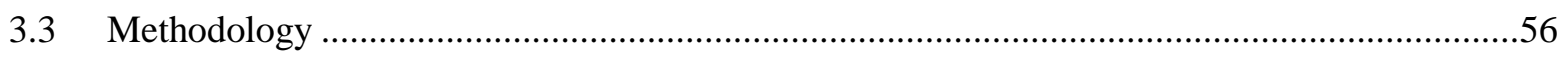

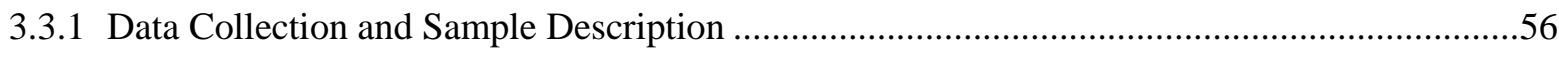

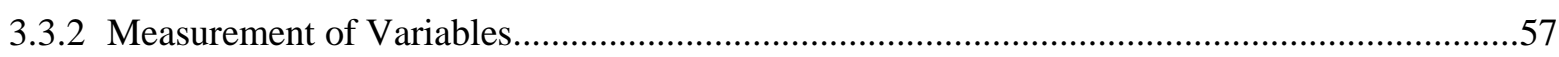

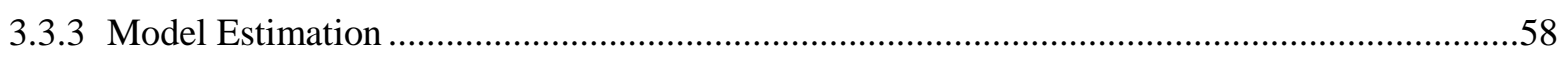

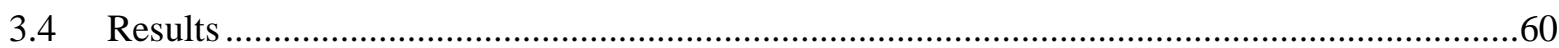

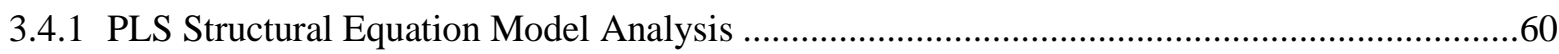

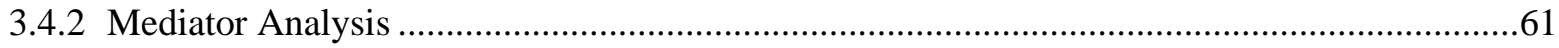

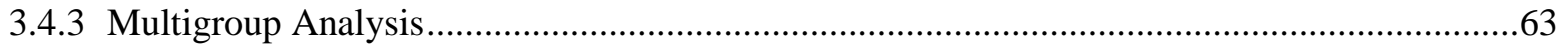

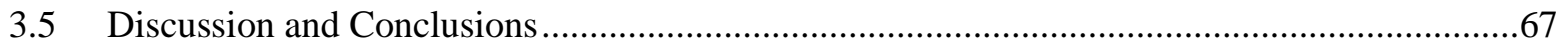

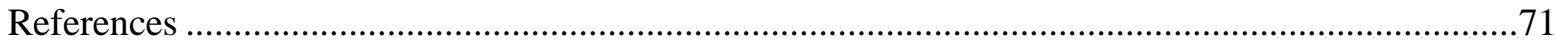

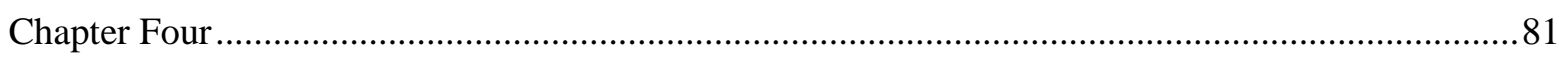

$4 \quad$ HomeVeg Tanzania Managing a New Strategy amidst GLIMPSE Challenges (Case

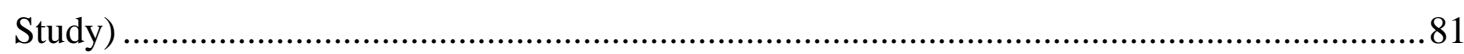

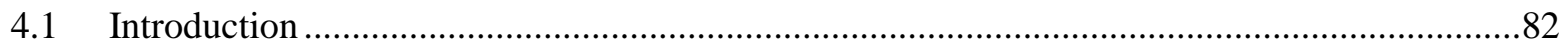

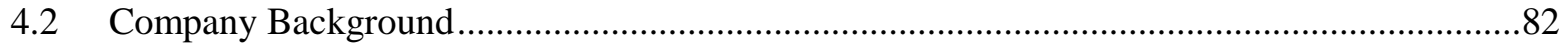

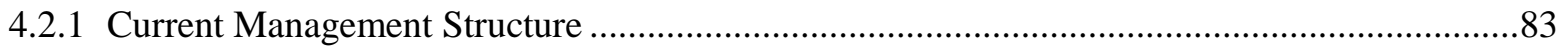

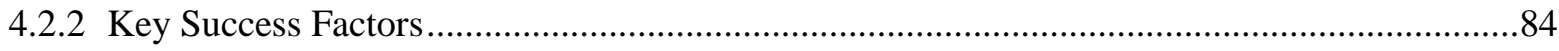

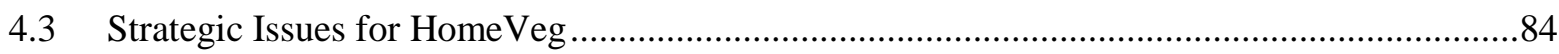

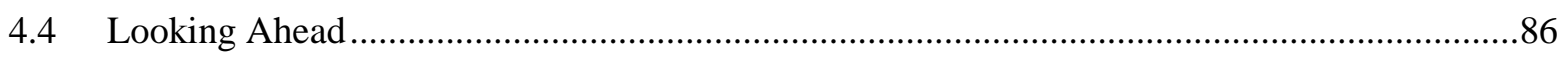

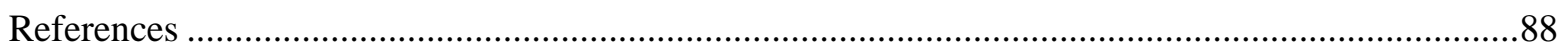

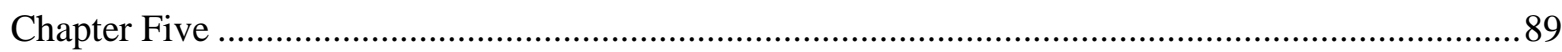

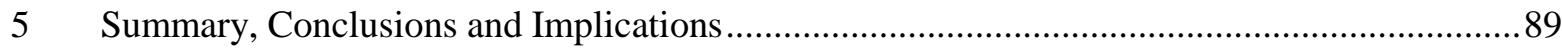

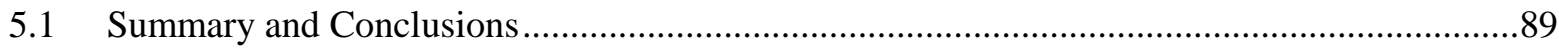

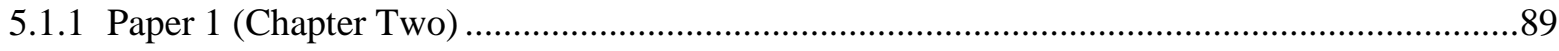

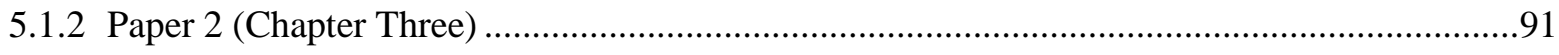

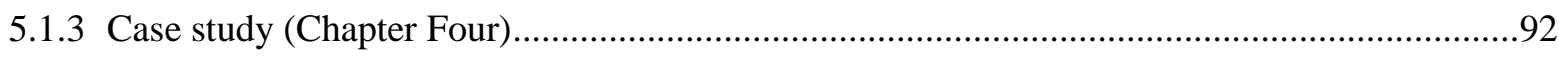

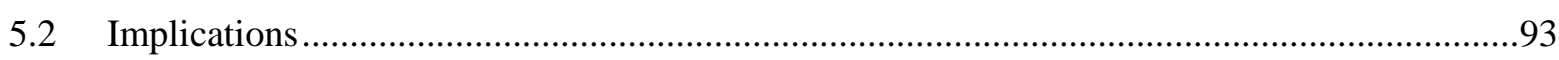




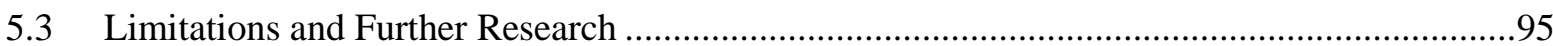

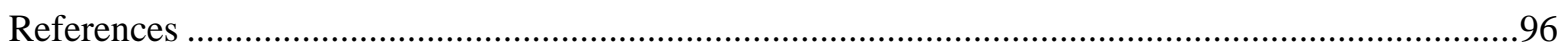

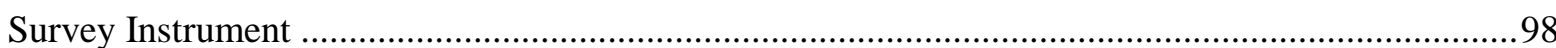

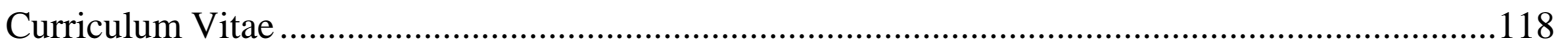




\section{List of Tables}

Table 1-1: Descriptive Statistics

Table 2-1: Descriptive Information about the Sample $(\mathrm{N}=229)$.............................................. 26

Table 2-2: Quality Criteria for Firm Characteristics Constructs ............................................ 28

Table 2-3: Quality Criteria for Reflective First Order Constructs ........................................ 28

Table 2-4: Quality Criteria for the Reflective First Order Constructs ................................... 28

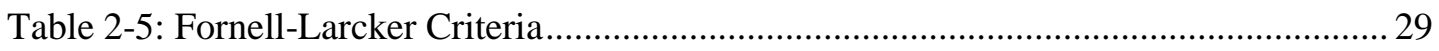

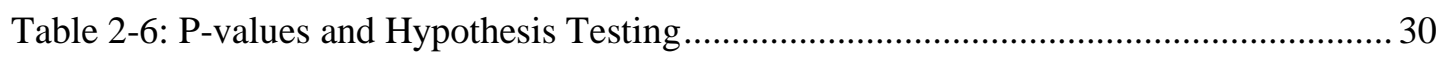

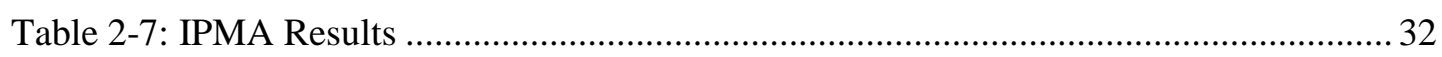

Table 3-1: Descriptive Information about the Sample $(\mathrm{N}=229)$........................................... 57

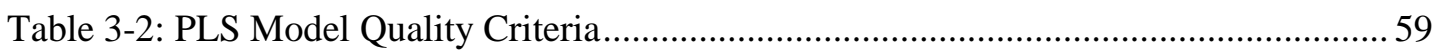

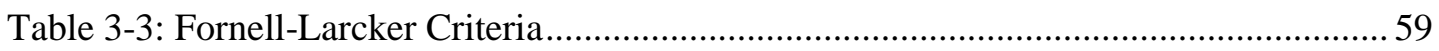

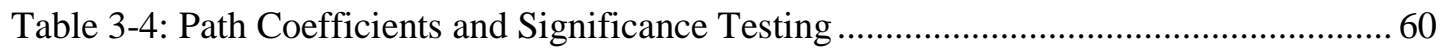

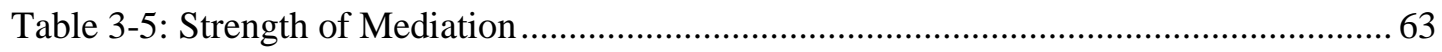

Table 3-6: FIMIX-PLS evaluation criteria and relative segment sizes .................................... 64

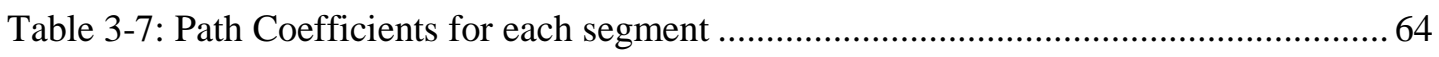

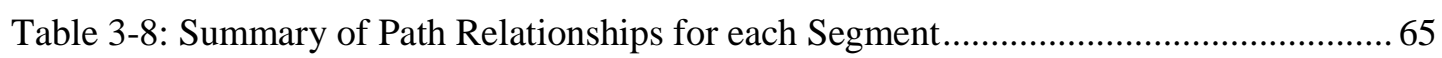




\section{List of Appendices}

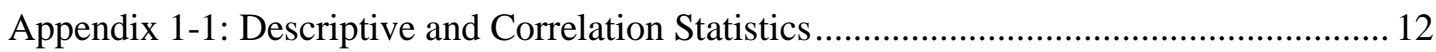

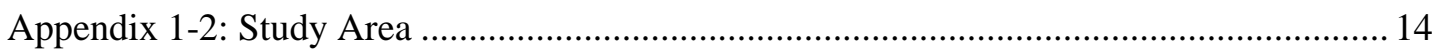

Appendix 2-1: Descriptive Statistics of Variable Items .......................................................... 44

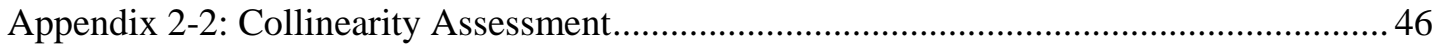

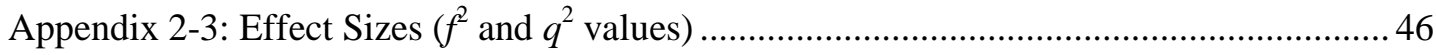

Appendix 3-1: Descriptive Statistics of Variable Items ........................................................... 77

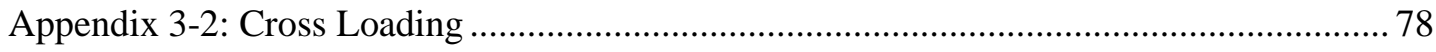

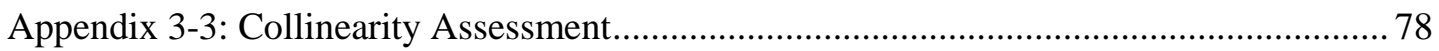

Appendix 3-4: Effect Sizes $\left(f^{2}\right.$ and $q^{2}$ Values) ................................................................ 78

Appendix 3-5: Validity and Reliability Measures (Multigroup analysis) _.............................. 79

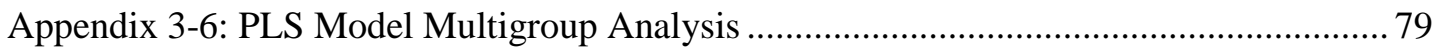

Appendix 3-7: Three-Segments PLS Analysis (Differences between Path Relationships) ... 80

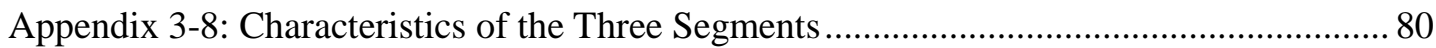

\section{List of Figures}

Figure 1-1: Wheelen and Hunger's Strategic Management Model ................................... 1

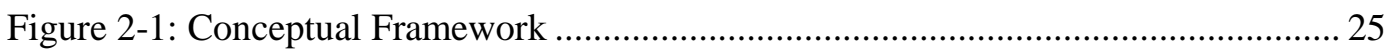

Figure 2-2: IPMA Representation of Determinants of STM Practices ............................. 33

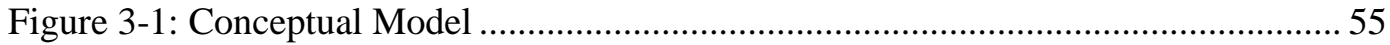

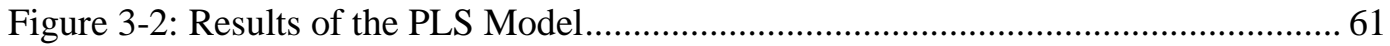




\section{List of Abbreviations}

\begin{tabular}{|c|c|}
\hline AGE & Firm age variable \\
\hline AVE & Average Variance Extracted \\
\hline $\mathrm{BRC}$ & British Retail Consortium \\
\hline $\mathrm{CR}$ & Composite Reliability \\
\hline CSDI & Center for Sustainable Development Initiative \\
\hline EXP & Level of managerial skills and expertise - variable \\
\hline FIMIX-PLS & Finite Mixture Partial Least Squares Approach \\
\hline FORM & Formalization status of a business firm -variable \\
\hline FUNDS & Access to external funds - variable \\
\hline GLIMPSE & $\begin{array}{l}\text { Government, Losses and wastage, Infrastructure, Markets, } \\
\text { Politics and policies, Science and innovation; and } \\
\text { Environment. }\end{array}$ \\
\hline GLOBALG.A.P & $\begin{array}{l}\text { Independent certification system for Good Agricultural } \\
\text { Practice }\end{array}$ \\
\hline $\mathrm{HCM}$ & Hierarchical Component Model \\
\hline HODECT & The Horticultural Development Council of Tanzania \\
\hline IFAMR & $\begin{array}{l}\text { The International Food and Agribusiness Management } \\
\text { Review }\end{array}$ \\
\hline INFO & Access to market information - variable \\
\hline INFRA & Access to public infrastructure - variable \\
\hline INPUT & Extent of input availability \\
\hline INVEST & Level of firm investment - variable \\
\hline IPMA & The Importance-Performance Matrix Analysis \\
\hline MAP & Monitoring Agri-trade Policy \\
\hline MoFEA & Ministry of Finance and Economic Affairs \\
\hline NBS & National Bureau of Statistics \\
\hline NSGRP & National Strategy for Growth and Reduction of Poverty \\
\hline PERF & Firm performance variable \\
\hline PLS & Partial Least Squares \\
\hline PLS-SEM & Partial Least Squares Structural Equation Modeling \\
\hline RBT & Resource Based View \\
\hline RBV & Resource Based Theory \\
\hline SEM & Structural Equation Modeling \\
\hline
\end{tabular}


SIDO

SIZE

SMEs

STM

$\mathrm{TZ}$

TZS

URT

USD

VAF

VIF

Small Industries Development Organizations

Firm size - variable

Small and Medium sized Enterprises

Strategic Management

Tanzania

Tanzanian Shillings (currency)

United Republic of Tanzania

United States Dollars (currency)

Variance Accounted For

Variance Inflation Factor 


\section{Summary}

Strategic management (STM) is recognized as an important element for firms' success; however, small firms, especially in agribusiness, have widely been overlooked because it is often thought that a systematic STM is exclusively for large corporate firms. Firms engage in STM practices such as environmental analysis, formulation of mission and vision statements, strategic planning, implementation, evaluation, etc., regardless of their size. The firms need to work out strategic plans to exploit the existing market, but past research shows that they differ in their capacity to implement and manage strategies. Whether or not they implement, the ability depends on the features of the firm itself, its resources and the conditions in the external environment. However, the need of STM practices for small firms is not well understood and the determinants for its successful application in small firms are not evidently known. With regard to African agribusiness firms, there is scant research on how the environmental factors determine the application of STM practices. Hence, using empirical data from 229 firms in Tanzania, the study conducts partial least squares structural equation modelling (PLS-SEM) analyses to estimate a model of the determinants of STM application that leads to firm performance, a mediating effect of STM application and a multigroup analysis by application of finite mixture PLS technique (FIMIX-PLS). Lastly, a case study is given to demonstrate challenges facing agribusiness firms in Tanzania.

In the first part of the analysis (Chapter two), the study explores to what extent the application of STM practices is affected by internal and external factors of the firms. Ideas from resource-based theory (RBT) and industrial organization (I/O) are used to build a conceptual model and formulation of hypotheses. Results show significantly that better strategic actions reside in the capabilities of firm managers, whereas many external factors, such as access to public infrastructure, did not turn out to have a significant influence. Application of STM was more prevalent in firms with extra access to funds. Hence the study calls on policymakers to accelerate, promote and advocate for more supportive services such as accessible financial services as well as managerial training programmes. Impacts of other factors are explained in detail. The findings have interesting implications for the management of agribusiness firms in African countries and other developing and emerging economies. 
In the second part of the analysis (Chapter three), a mediation analysis is performed to demonstrate the role of strategic management in facilitating effective use of resources to achieve performance. Using 'level of managerial expertise' and 'access to market information' as primary resources, this research presents various arguments about their contribution to firm performance. Results indicate that the investigated resources alone do not directly contribute to firm performance unless there is an application of strategic management. Further investigation based on multigroup analysis shows three groups of firms which differ in their resources-performance relationship. The results imply that the small firms' paths to achieve performance are different hence managers ought to identify a fit between their resources and strategic actions in order to improve the firm performance. The study provides manifold managerial implications for small firms that seek to improve firm performance. It is useful for small firm managers to apply modern management techniques of firm operations in order to make timely strategic decisions depending on the available resources.

Lastly, the case study explains challenges that can affect achievement of firms' strategies for agribusiness firms in Tanzania (Chapter four). Some of these challenges include: stringent business regulations, poor availability of storage facilities, poor infrastructure, inability to penetrate international markets, poor progress in the implementation of policy recommendations and poor collaboration between scientist, researchers and actors in food supply chains. Considering the challenges, the firms should focus on improving their business skills, engage in public-private partnership programs and communicate policy shortfalls to the government.

Overall, this study provides an early inquiry into small firms' STM application. More progress surrounding the application can be further explained with the help of indepth case studies and analyses of longitudinal data. 


\section{Chapter One}

\section{General Introduction}

\subsection{Background Information}

\subsubsection{Role of Strategic Management and its Role on Attainment of Firm Objectives}

Strategic management (STM) has become an essential managerial tool for business firms in today's competitive environments (Grant, 2013). It involves a set of decisions and actions that determine the long run performance of a firm. Its practices include environmental analysis, strategy planning, implementation, evaluation and control (Wheelen \& Hunger, 2012) (Figure 1-1). The strategic management process helps managers to focus on opportunities for growth, react to competitors' actions and better utilize firm resources. STM also provides firms and employees with a clear direction for future developments to achieve performance goals. Moreover, it reduces risks of unforeseen problems around firms' environment.

Figure 1-1: Wheelen and Hunger's Strategic Management Model

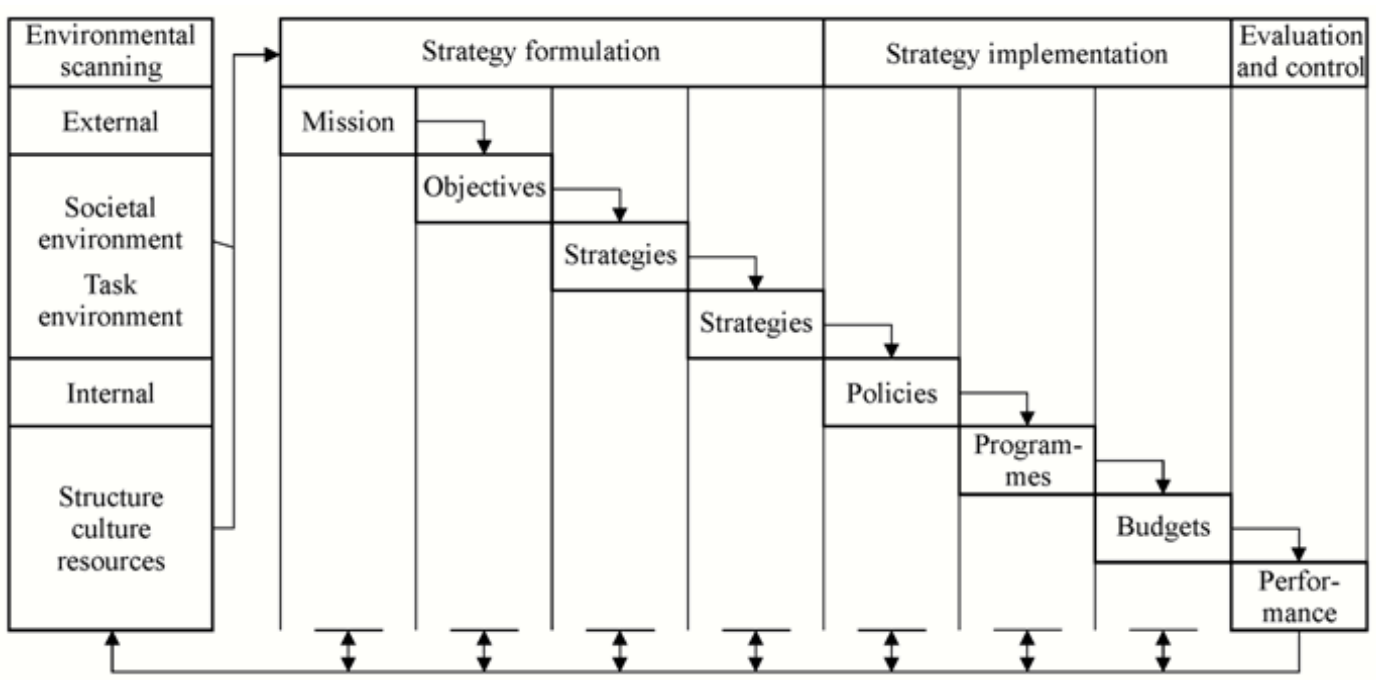

(Wheelen \& Hunger, 2006) 
The value and importance of STM practices has been recognized and comparatively appreciated. Since its evolution strategic management has been directed towards facilitating organizational responses to the environment (Andrews, 1971; BCG, 1968). Firm managers are encouraged to develop a certain way of thinking that enables them to understand opportunities from environmental situations, and eventually make decisions that lead to performance (Steiner \& Miner, 1977). In later and current years, many researchers have looked at the link between STM practices and firm performance (Andrews et al., 2006; Beaver 2002; Bracker \& Pearson 1986; Chen, 2005; Dibrell et al. 2014; Georgellis et al., 2000; Stacey, 2011) while indicating a positive link and suggesting several contributing factors.

\subsubsection{Strategic Management in Small Agribusiness Firms in Developing Countries}

Many research studies have focused on the performance of small agribusiness firms in developing economies. This is mainly due to the firms' important impact on net employment, welfare development and poverty reduction (Doern, 2009; Kinda \& Loening, 2010). However, current practices on how small firms' managers operate are insufficient to improve overall firm performance. Using an example of food processors ${ }^{1}$ in Tanzania, the firms' contribution to the economy of the country is relevant because the food processing industry in the country consists of a large number of small and micro firms ${ }^{2}$ operating in both a formal and an informal manner. Several reports indicate that there are weak competitiveness and poor managerial skills (Fafchamps \& Quinn, 2012; IFAMR, 2014). Likewise, the firms are faced with several constraints such as poor access to funds, poor public service infrastructure, limited capital availability, poor access to market information, etc. which have imposed challenges for firm managers to achieve their strategies (Dietz et al. 2000; Dinh et al. 2013).

The level of competitiveness of small agribusiness companies in the market is still poor and not improving, despite the fact that the markets for processed food products have been expanding and the demand for food is expected to double within the next 30

\footnotetext{
${ }^{1}$ Actors (agribusiness traders) in food supply chains dealing with purchase of raw produce from farmers, food manufacturing, packing, labelling and marketing.

${ }^{2}$ Capital less than 12000 US-Dollars
} 
years (Dietz et al., 2000; Dinh et al., 2013). Furthermore, there are large trade deficits in the agro processing sector and a poor improvement of agro products' quality (Dinh et al., 2013; World Bank, 2012). Several efforts have been made by the governments and private institutions to improve the capacity of managers by providing supporting services such as financial capital, credit guarantees, micro insurance, training, etc. (Dietz et al., 2000; MoFEA, 2010). However, the route of how the managers drive their firm organizations to survive in the markets is not well understood (URT 2007). With this regard, there is a need to investigate in more detail agribusiness management and how the resources are controlled and utilized for the future development of small agribusiness firms (Conforte, 2011). There is a need to take a closer look inside firm operations in order to assess the capability of the firms to plan, implement, evaluate and control their strategies. Specifically, it is essential to examine the factors that enable a firm's capacity to do so.

Strategic management practices are often assumed to be exclusively utilized by large corporate firms and considered irrelevant for small business firms. However, previous studies indicate its importance to small firms as well (W. Anderson, 2012; Biggs \& Shah, 2006; Doern, 2009; Edelman, Brush, \& Manolova, 2005; Edelman \& Brush, 2001; Kinda \& Loening, 2010). The studies highlighted the huge importance of 'strategy' to enhance small business growth. The applicability of strategic management to small firms was found to be scanty and small firm managers refuse to embrace the strategic management process due to the following reasons:

(1) It is a time consuming process compared to the day to day firm operations activities;

(2) The managers are not well enough educated to know the terms used in STM tools such as business plans, balance sheets, cash flow, profit and loss statements, etc.

(3) There is a negative perception in paying for extra interventions such as business consultants or training programs (considering the limited resources and capital availability of small firms) (Beaver, 2007).

As a result, the firms fail to perform due to their inability to manage, for instance, growth and accounting procedures. Furthermore, many companies are characterized by a poor strategy to reach the customer due to a lack of transparency of the exchange of 
business information between managers and employees, a wide-spread failure to develop control systems, and many more. Contemporary research has indicated repeatedly that strategic thinking and planning are strongly related to small firm business performance (Beaver, 2002, 2007).

In Tanzania, there are large numbers of small processing enterprises that are either registered or not registered and mostly invisible to statisticians. The food production premises are ever-changing. For example small firm workers may sort, pack, label and sell fruits, vegetables, rice, maize and other cereals in the owners' backyards, in a temporary (half-built) production facility or in a permanent production facility (Dietz et al., 2000). The situation has not changed much over the years and is quite similar to other developing economies in Sub-Saharan Africa (Byerlee et al., 2013; World Bank, 2012). The firms sell their products primarily to domestic markets while trying to meet customers' demands and at the same time attempting to penetrate global markets. Despite their efforts, these firms encounter challenges in implementing strategies due to limited capital compared to larger companies. These challenges are related to their limited firm size and experience. Other challenges are due to limited availability of resources such as low investment level, limited access to market information and low level of managers' expertise. Moreover, pressures from the external environment such as input availability, access to funds, and access to public service infrastructure are factors that can push or hinder firms' ability to strategize. Considering the industrial organization and resourcebased views in the strategic management literature (Grant, 2013), these factors are critical links to implementation of firm strategies and attainment of firm performance.

For the purpose of identifying research gaps, several studies show contradicting arguments for each of the factor's contribution to the effective implementation of firm strategies. But, there is no clear explanation on why some firms of the same nature perform better than others in achieving their strategies while operating in a similar environment. The truth is that we know very little so far about management practices of agribusiness firms (Conforte, 2011) and how they differ in their capacity to implement and manage strategies. All in all, our current understanding of the small firms' attainment of strategies is limited, especially with regard to small agribusiness firms in developing economies. 


\subsection{Research Objective}

The first research objective is to explore strategic management practices of agribusiness firms (using a sample of food manufacturers and processors) in order to understand to what extent their application is affected by internal and external factors of the firm environments. The study (see Chapter two) employs ideas from the resourcebased theory (RBT) and industrial organization to create a conceptual framework ${ }^{3}$ and bring out critical factors that enhance a fit between a firm's internal and external situation, its STM practices and firm performance. Since existing literature shows contradicting arguments about the determinants of the successful application of STM practices, several hypotheses are formulated and tested. The findings will provide practical knowledge for agribusiness firms in managing their daily operations, especially now that with constant emergence of new markets there is much more exposure to competition. The firm managers will be informed on better STM tools applicable in their environment, as many of them have limited experience in running an enterprise. Furthermore, the country of research is now focusing on the transformation of small and medium-sized enterprises (SMEs) from traditional into modern professional commercial firms (URT, 2010).

The second research objective is to perform further analysis to demonstrate the role of strategic management in facilitating an effective use of resources to achieve performance (see Chapter three). This is because previous studies have shown the critical link between resources and success but other studies indicate that resources alone cannot contribute towards firms' success; instead they highlight the connection between the availability of resources and firm strategy and its management. Technically, we will apply mediation analysis to investigate the relationship between firm resources, strategic management practices and firm performance. The analysis will further reveal differences among firms regarding the deployment of firm resources such as managerial skills and market information. Due to the fact that the small firms and their paths to achieve sustainable growth are different, the findings will suggest alternative paths to sustainable success. Therefore, managers are encouraged to carefully utilize the strengths of their resources and develop related strategies to gain high returns. Since the food processing sub-sector is a large component of the manufacturing industry, especially in the

\footnotetext{
${ }^{3}$ See Figure 2-1 Chapter two.
} 
developing economies, any improvement will have an important impact on the competitiveness of the agribusiness sector as a whole.

The third research objective is to identify challenges facing agribusiness firms in Africa in achieving their strategies. An empirical example is given by demonstrating a short case study from Tanzania (Chapter four).

\subsection{The Sample}

\subsubsection{Descriptive Statistics of the Sample}

The sample consists of 229 firms dealing with food processing of cereals (65.9\%), vegetables (16.4\%) and fruits (11.5\%), located in Arusha, Dodoma and Tanga regions in Tanzania ${ }^{4}$. It was collected between May and August, 2013 through a cross sectional survey. Data was collected through interviews with firm owners and managers with an aid of a structured questionnaire. The selection of food processors followed a random sampling technique. In general, the firms have a mean capital investment of 26.94 million TZS $\left(\approx 16,600\right.$ US $\left.\$^{5}\right)$ and an average of $7 \frac{1}{2}$ years of business operations. The respondents of this study were both owners and managers of the firm or a manager in charge. They were knowledgeable about general overview of the firms and cornerstones of their strategies. The respondents' ages ranged from 18 to 78 years (average: 43 years), with an average of 11.05 years of school education.

Table 1-1 indicates further details of the characteristics of the interviewer (i.e. the firm owner-manager) and the firm. The data presents a brief summary of our raw data. It does not however indicate whether these differences have statistical significance.

\subsubsection{Status of Strategic Management (STM) Practices}

The application of strategic management (STM) practices is indicated as a key variable in all structural model analyses performed in Chapters two and three. The variable includes a total of 17 statements that are condensed to four categories of STM practices; (1) environmental analysis, (2) strategy planning, (3) strategy implementation

\footnotetext{
${ }^{4}$ See Appendix 1-2: Study Area

${ }^{5} 1 \mathrm{USD}=1,623 \mathrm{TZS}$ exchange rate prevailing on $1^{\text {st }}$ August 2013 www.bot-tz.org
} 
and (4) strategy evaluation and control. The managers were asked to rate the application of these STM practices on five point Likert scales of 1 to 5 .

\section{Table 1-1: Descriptive Statistics}

\begin{tabular}{|c|c|c|c|c|c|c|}
\hline \multirow[b]{2}{*}{ Variables } & \multicolumn{5}{|c|}{ Application of STM practices $\overline{\mathrm{x}}(\mathrm{s})$} & \multirow{2}{*}{$\begin{array}{c}\text { Total } \\
\text { STM } \\
\text { score } \\
\overline{\mathrm{x}}(\mathrm{s})\end{array}$} \\
\hline & $\begin{array}{l}\% \text { of } \\
\text { full } \\
\text { sample }\end{array}$ & $\begin{array}{c}\text { Environ } \\
\text { mental } \\
\text { analysis }\end{array}$ & $\begin{array}{l}\text { Strategy } \\
\text { planning }\end{array}$ & $\begin{array}{c}\text { Strategy } \\
\text { implementat } \\
\text { ion. }\end{array}$ & $\begin{array}{c}\text { Strategy } \\
\text { control \& } \\
\text { evaluation }\end{array}$ & \\
\hline Overall & $100 \%$ & $\begin{array}{c}3.47 \\
(1.19)\end{array}$ & $\begin{array}{c}3.28 \\
(1.14)\end{array}$ & $\begin{array}{c}3.21 \\
(1.09)\end{array}$ & $\begin{array}{c}3.31 \\
(1.22)\end{array}$ & $\begin{array}{c}\mathbf{3 . 3 2} \\
(1.09)\end{array}$ \\
\hline \multicolumn{7}{|l|}{ Firm location } \\
\hline Region 1 (Arusha) & $27.1 \%$ & $\begin{array}{l}3.28 \\
(1.02)\end{array}$ & $\begin{array}{c}3.19 \\
(0.98)\end{array}$ & $\begin{array}{l}3.19 \\
(0.96)\end{array}$ & $\begin{array}{l}3.28 \\
(1.07)\end{array}$ & $\begin{array}{c}3.21 \\
(0.95)\end{array}$ \\
\hline Region 2 (Dodoma) & $45.9 \%$ & $\begin{array}{c}3.91 \\
(1.03)\end{array}$ & $\begin{array}{l}3.65 \\
(0.98)\end{array}$ & $\begin{array}{c}3.60 \\
(0.94)\end{array}$ & $\begin{array}{c}0.82 \\
(17.23)\end{array}$ & $\begin{array}{c}3.72 \\
(0.91)\end{array}$ \\
\hline Region 3 (Tanga) & $27.1 \%$ & $\begin{array}{l}2.92 \\
(1.35)\end{array}$ & $\begin{array}{c}2.76 \\
(1.29)\end{array}$ & $\begin{array}{c}2.57 \\
(1.17)\end{array}$ & $\begin{array}{l}2.65 \\
(1.33)\end{array}$ & $\begin{array}{l}2.75 \\
(1.22)\end{array}$ \\
\hline \multicolumn{7}{|l|}{ Education level (3 groups) } \\
\hline $\begin{array}{l}\text { Years of education } \\
\text { Low (below } 11 \text { years) }\end{array}$ & $34.5 \%$ & $\begin{array}{c}3.03 \\
(1.24)\end{array}$ & $\begin{array}{l}2.86 \\
(1.12)\end{array}$ & $\begin{array}{c}2.76 \\
(1.09)\end{array}$ & $\begin{array}{c}0.35 \\
(16.16)\end{array}$ & $\begin{array}{c}2.88 \\
(1.09)\end{array}$ \\
\hline $\begin{array}{l}\text { Middle (between } 11 \\
\text { and } 12 \text { years) }\end{array}$ & $34.1 \%$ & $\begin{array}{c}3.79 \\
(1.02)\end{array}$ & $\begin{array}{l}3.53 \\
(1.02)\end{array}$ & $\begin{array}{c}3.51 \\
(0.99)\end{array}$ & $\begin{array}{c}3.60 \\
(1.14)\end{array}$ & $\begin{array}{l}3.61 \\
(0.95)\end{array}$ \\
\hline $\begin{array}{l}\text { High (above } 12 \text { years } \\
\text { of education ) }\end{array}$ & $31.4 \%$ & $\begin{array}{c}3.61 \\
(1.19)\end{array}$ & $\begin{array}{c}3.48 \\
(1.14)\end{array}$ & $\begin{array}{c}3.39 \\
(1.05) \\
\end{array}$ & $\begin{array}{c}2.01 \\
(12.13)\end{array}$ & $\begin{array}{c}3.49 \\
(1.09) \\
\end{array}$ \\
\hline \multicolumn{7}{|l|}{ Age of owner manager } \\
\hline $\begin{array}{l}\text { Young managers_38 } \\
\text { years and below }\end{array}$ & $36.8 \%$ & $\begin{array}{c}3.50 \\
(1.03)\end{array}$ & $\begin{array}{c}3.31 \\
(0.94)\end{array}$ & $\begin{array}{c}3.28 \\
(0.89)\end{array}$ & $\begin{array}{c}2.03 \\
(11.34)\end{array}$ & $\begin{array}{c}3.36 \\
(0.89)\end{array}$ \\
\hline $\begin{array}{l}\text { Middle aged managers } \\
\text { _ } 39 \text { to } 47 \text { years }\end{array}$ & $30.9 \%$ & $\begin{array}{c}3.39 \\
(1.33)\end{array}$ & $\begin{array}{c}3.14 \\
(1.27)\end{array}$ & $\begin{array}{l}3.15 \\
(1.20)\end{array}$ & $\begin{array}{c}0.33 \\
(17.34)\end{array}$ & $\begin{array}{c}3.23 \\
(1.22)\end{array}$ \\
\hline $\begin{array}{l}\text { Older managers_ } 48 \\
\text { years and above }\end{array}$ & $32.3 \%$ & $\begin{array}{c}3.50 \\
(1.25)\end{array}$ & $\begin{array}{c}3.37 \\
(1.18)\end{array}$ & $\begin{array}{c}3.20 \\
(1.21) \\
\end{array}$ & $\begin{array}{c}3.39 \\
(1.26)\end{array}$ & $\begin{array}{c}3.36 \\
(1.17) \\
\end{array}$ \\
\hline \multicolumn{7}{|l|}{ Age of firm (years) } \\
\hline $\begin{array}{l}\text { Young firms_ } \leq 4 \\
\text { years }\end{array}$ & $36.8 \%$ & $\begin{array}{c}2.86 \\
(1.27)\end{array}$ & $\begin{array}{c}2.70 \\
(1.16)\end{array}$ & $\begin{array}{c}2.51 \\
(1.04)\end{array}$ & $\begin{array}{c}1.22 \\
(11.95)\end{array}$ & $\begin{array}{l}2.69 \\
(1.10\end{array}$ \\
\hline $\begin{array}{l}\text { Middle aged firms }{ }_{-} 4 \\
<\mathrm{X} \leq 8 \text { years }\end{array}$ & $30.9 \%$ & $\begin{array}{c}3.58 \\
(1.08)\end{array}$ & $\begin{array}{c}3.39 \\
(1.05)\end{array}$ & $\begin{array}{c}3.34 \\
(0.97)\end{array}$ & $\begin{array}{c}3.38 \\
(1.08)\end{array}$ & $\begin{array}{c}3.44 \\
(0.98)\end{array}$ \\
\hline Old firms_ $>8$ years & $32.3 \%$ & $\begin{array}{c}3.95 \\
(0.99)\end{array}$ & $\begin{array}{c}3.74 \\
(0.96)\end{array}$ & $\begin{array}{c}3.78 \\
(0.90)\end{array}$ & $\begin{array}{c}1.05 \\
(17.31)\end{array}$ & $\begin{array}{c}3.82 \\
(0.89)\end{array}$ \\
\hline \multicolumn{7}{|l|}{ Core product category } \\
\hline Cereals & $65.9 \%$ & $\begin{array}{c}3.56 \\
(1.09)\end{array}$ & $\begin{array}{c}3.32 \\
(1.07)\end{array}$ & $\begin{array}{c}3.24 \\
(1.02)\end{array}$ & $\begin{array}{c}3.37 \\
(1.15)\end{array}$ & $\begin{array}{c}3.37 \\
(1.00)\end{array}$ \\
\hline Fruits & $16.4 \%$ & $\begin{array}{c}3.19 \\
(1.43)\end{array}$ & $\begin{array}{c}3.13 \\
(1.29)\end{array}$ & $\begin{array}{c}3.07 \\
(1.26)\end{array}$ & $\begin{array}{c}3.15 \\
(1.43)\end{array}$ & $\begin{array}{c}3.13 \\
(1.29)\end{array}$ \\
\hline Vegetables & $11.5 \%$ & $\begin{array}{c}2.96 \\
(1.33)\end{array}$ & $\begin{array}{c}2.94 \\
(1.38)\end{array}$ & $\begin{array}{c}2.89 \\
(1.31)\end{array}$ & $\begin{array}{c}2.86 \\
(1.38)\end{array}$ & $\begin{array}{c}2.93 \\
(1.32)\end{array}$ \\
\hline
\end{tabular}

Notes:

Mean values are shown with standard deviations in parentheses. Score values of the application of STM practices ( 4 categories), the mean values range between 1 and 5 , where 5 is the highest score. $\overline{\mathrm{x}}(\mathrm{s})$ - Mean (standard deviation). 
Table 1-1 indicates that the average score on the application of STM is 3.32 (s $=1.09$ ), whereby 1 is the lowest and 5 the highest score; however, the scores vary according to the characteristics of the firms as well as of the manager. For example; summary on firm location shows that firms located in Tanga region scored less in the application of STM practices compared to firms located in other regions i.e. Arusha and Dodoma. Summary of other scores are shown with respect to education level, age of the firm, product variety, etc.

Furthermore, we ran a correlation analysis to get a preliminary idea on direction of the relationships between STM practices and factors from the internal and external environments of the firm. The analyses indicate a series of weak and strong relationships between the variables. Therefore, before analyzing our structural equation model (in Chapters two and three), we see that positive correlation exists between STM practices and factors such as; managerial expertise, firm size, formalization status and increase in sales. However, negative association exists with 'self-financed' status of the firm ( $\mathrm{r}=$ 0.31), meaning that the firms which generate their growth capital from firm's income instead of acquiring additional funds from external sources have less ability to apply STM practices. That is why there is a negative correlation with practices such as environmental analysis $(\mathrm{r}=-0.3)$, strategy planning $(\mathrm{r}=-0.303)$, strategy implementation $(r=-0.266)$ and strategy control $(r=-0.310)$. More summary of our data is given in Appendix 1-1.

\subsection{Outline of the Dissertation}

The dissertation is structured as follows: Chapter two presents a paper titled 'The Impact of External and Internal Factors on Strategic Management Practices of Agribusiness Firms in Tanzania'. The main research questions are: What is the influence of internal and external factors on the successful implementation of a firm's strategic management practices? What is the implication of these influences to managerial decisions? In this paper, a conceptual model is developed for the study to test a number of hypothesized relationships by using primary data from the 229 firms in our sample. We apply partial least square - structural equation modeling (PLS-SEM) through smartPLS 2.0 M3 software (Ringle et al., 2005). Thereafter, an illustration from the importance performance matrix analysis (IPMA) is included in the analysis section to 
demonstrate a 'priority map' for managerial decisions. The paper was published in the GlobalFood Discussion Paper Series and is currently under review in an international peer-reviewed journal.

Chapter three presents a paper titled 'Agribusiness Firm Resources and Performance: The Mediating Role of Strategic Management Practices'. The paper aims to answer additional research questions: Do strategic management practices mediate the relationship between firm resources and firm performance? Are there significant differences among firms in the role of strategic management practices as a mediating variable? As stated in the previous chapter, we apply partial least square - structural equation modeling (PLS-SEM) to estimate a resource-strategy-performance ${ }^{6}$ model for mediation analysis. Thereafter, multigroup analysis is conducted to uncover heterogeneity within the sample by using STM as a mediator variable in the model. We apply FIMIX-PLS technique in conducting the multigroup analysis (Hahn et al., 2002; Sarstedt et al., 2011). The technique is also available in the smartPLS 2.0 M3 software. The paper was published in the GlobalFood Discussion Paper Series and is currently under review for journal submission.

Chapter four presents a paper titled: 'HomeVeg Tanzania: Managing a New Strategy amidst GLIMPSE Challenges' The paper is written using case study research approach. Data was collected primarily by conducting unstructured interviews with the owner and employees of the agribusiness firm under analysis. The production facility of HomeVeg Ltd. was visited between June and July 2013. Basically, the case discusses a journey towards planning and implementing a firm strategy concerning product market entry. Real examples on challenges relating to Government, losses and wastage, infrastructure, markets, politics and policies, science and innovation, and environment (GLIMPSE) were given. The case was published in 2014 in the special issue of the International Food and Agribusiness Management Review (IFAMR).

A summary and some concluding remarks follow in the last section of this dissertation. Furthermore, some managerial implications are derived from the empirical results. Limitations of the research approach applied in this thesis and some ideas for future research directions close the dissertation.

\footnotetext{
${ }^{6}$ See Figure 3-1 Chapter three.
} 


\section{References}

Anderson, W. (2012). A Gender-based Comparison of Marketing Strategies of SMEs in Tanzania. International Journal of Marketing Principles and Practices, 2(1), 32-42.

Andrews, K. R. (1971). The concept of corporate strategy. Homewood, III: Dow Jones-Irwin.

Andrews, R., Boyne, G. A., \& Walker, R. M. (2006). Strategy content and organizational performance: An empirical analysis. Public Administration Review, 66(January-February), $52-63$.

Beaver, G. (2002). Strategy and Management in the Smaller Enterprise. Strategic Change, 11(4), $175-181$.

Beaver, G. (2007). The strategy payoff for smaller enterprises. Journal of Business Strategy, 28(1), 11-17. Retrieved from http://www.emeraldinsight.com/10.1108/02756660710723161

Biggs, T., \& Shah, M. K. (2006). African SMES, Networks, and Manufacturing Performance. Journal of Banking \& Finance, 30(11), 3043-3066.

Boston Consulting Group BCG. (1968). Perspectives on experience. Boston, Mass: The Group.

Bracker, J. S., \& Pearson, J. N. (1986). Planning and Financial Performance of Small, Mature Firms. Strategic Management Journal, 7(6), 503-522.

Byerlee, D., Garcia, A. F., Giertz, A., \& Palmadesa, V. (2013). Growing Africa: Unlocking the Potential of Agribusiness. The World Bank. Retrieved August 17, 2014, from http://documents.worldbank.org/curated/en/2013/03/17427481/ growing-africa-unlockingpotential-agribusiness-vol-1-2-main-report

Chen, H. (2005). A Competence-based Strategic Management Model Factoring in Key Success Factors and Benchmarking. Benchmarking: An International Journal, 12(4), 364-382.

Conforte, D. (2011). The Nature of Agribusiness Management Research Executive Commentary. International Food and Agribusiness Management Review, 14(2), 143-147.

Dibrell, C., Craig, J. B., \& Neubaum, D. O. (2014). Linking the formal strategic planning process, planning flexibility, and innovativeness to firm performance. Journal of Business Research, 67(9), 2000-2007.

Dietz, M. H., Matee, S., \& Ssali, W. (2000). Assessment of the Small-scale Food Processing Subsector in Tanzania and Uganda: Study Report (p. 65). The Technical Centre for Agricultural and Rural Cooperation CTA, Wageningen, Netherlands.

Dinh, H. T., Monga, C., Morisset, J., Kweka, J., Yagci, F., \& Yoshino, Y. (2013). Light manufacturing in Tanzania: A reform agenda for job creation and prosperity (p. 116). Washington DC 20001: The World Bank.

Doern, R. (2009). Investigating barriers to SME growth and development in transition environments: A critique and suggestions for developing the methodology. International Small Business Journal, 27(3), 275-305. 
Edelman, L. F., \& Brush, C. G. (2001). The Mediating Role of Strategy on Small Firm Performance. 2001 Academy of Management Research Conference (p. 50). Waltham, MA 02453.

Edelman, L. F., Brush, C. G., \& Manolova, T. (2005). Co-alignment in the resource-performance relationship: strategy as mediator. Journal of Business Venturing, 20(3), 359-383.

Georgellis, Y., Joyce, P., \& Woods, A. (2000). Entrepreneurial action, innovation and business performance: The small independent business. Journal of Small Business and Enterprise Development, 7(1), 7-17.

Grant, R. M. (2013). Contemporary Strategy Analysis: Text and Cases (8th ed., p. 842). West Sussex, UK: John Wiley \& Sons, Inc.

Hahn, C., Johnson, M. D., Herrmann, A., \& Huber, F. (2002). Capturing Customer Heterogeneity Using a Finite Mixture PLS Approach. Schmalenbach Business Review, 54(July), 243-269.

Kinda, T., \& Loening, J. L. (2010). Small Enterprise Growth and the Rural Investment Climate: Evidence from Tanzania. African Development Review, 22(1), 173-207.

Ministry of Finance and Economic Affairs. (2010). National Strategy for Growth and Reduction of Poverty II: NSGRP II. Retrieved July 20, 2014, from http://www.acdicida.gc.ca/INET/IMAGES.NSF/vLUImages/Tanzania/\$file/NATIONAL-STRATEGYFOR-GROWTH-AND-REDUCTION-OF-POVERTY-TANZANIA.PDF

Ringle, C. M., Wende, S., \& Will, A. (2005). SmartPLS 2. Hamburg: SmartPLS. Retrieved from http://www.smartpls.com

Sarstedt, M., Becker, J.-M., Ringle, C. M., \& Schwaiger, M. (2011). Uncovering and Treating Unobserved Heterogeneity with FIMIX-PLS: Which Model Selection Criterion Provides an Appropriate Number of Segments? Schmalenbach Business Review, 63(January), 34-62.

Stacey, R. D. (2011). Strategic management and Organisational Dynamics: The Challenge of Complexity (6th ed.). Upper Saddle River, NJ: Pearson Prentice Hall/Financial Times Press.

Steiner, G. A., \& Miner, J. B. (1977). Management policy and strategy: Text, readings, and cases. New York: Macmillan.

United Republic of Tanzania. (2007). Poverty and Human Development Report 2007 (p. 198). Ministry of Planning, Economy and Empowerment, Ministry of Planning, Economy and Empowerment, REPOA, Dar es Salaam.

United Republic of Tanzania. (2009). Nguzo kumi za kilimo kwanza, 1-25.

Wheelen, T. L., \& Hunger, J. D. (2006). Strategic Management and Business Policy. Upper Saddle River, NJ: Pearson Education, Inc.

Wheelen, T. L., \& Hunger, J. D. (2012). Strategic Management and Business Policy: Towards Global Sustainability. Upper Saddle River, N.J: Pearson Prentice Hall.

World Bank. (2012). Performance of Manufacturing Firms in Africa: An Empirical Analysis. (H. T. Dinh \& G. R. G. Clarke, Eds.) (Directions., p. 211). Washington DC 20433: International Bank for Reconstruction and Development / The World Bank. 


\section{Appendix 1-1: Descriptive and Correlation Statistics}

\begin{tabular}{|c|c|c|c|c|c|c|}
\hline \multirow[b]{2}{*}{ Variables } & \multirow[b]{2}{*}{$\overline{\mathrm{x}}(\mathrm{s})$} & \multicolumn{4}{|c|}{$\begin{array}{c}\text { STM practices } \\
\text { correlation (sig. 2-tailed) }\end{array}$} & \multirow[b]{2}{*}{$\begin{array}{l}\text { Total } \\
\text { STM }\end{array}$} \\
\hline & & $\begin{array}{c}\text { Environm } \\
\text { ental } \\
\text { analysis }\end{array}$ & $\begin{array}{l}\text { Strategy } \\
\text { planning }\end{array}$ & $\begin{array}{c}\text { Strategy } \\
\text { implementa } \\
\text { tion }\end{array}$ & $\begin{array}{l}\text { Strategy } \\
\text { control }\end{array}$ & \\
\hline Managers education (years) & $\begin{array}{l}11.05 \\
(3.51)\end{array}$ & $\begin{array}{l}0.233 * * * \\
(0.000)\end{array}$ & $\begin{array}{c}0.272 * * * \\
(0.000)\end{array}$ & $\begin{array}{c}0.274 * * * \\
(0.000)\end{array}$ & $\begin{array}{c}0.213 * * * \\
(0.001)\end{array}$ & $\begin{array}{r}0.283 * * * \\
(0.000)\end{array}$ \\
\hline Age of owner-manager & $\begin{array}{c}43 \\
(10.7)\end{array}$ & $\begin{array}{l}0.029 \\
(0.670)\end{array}$ & $\begin{array}{l}0.049 \\
(0.462\end{array}$ & $\begin{array}{l}0.004 \\
(0.957)\end{array}$ & $\begin{array}{l}0.073 \\
(0.280)\end{array}$ & $\begin{array}{l}0.050 \\
(0.460)\end{array}$ \\
\hline $\begin{array}{l}\text { Manager's years of experience in } \\
\text { the firm (years.) }\end{array}$ & $\begin{array}{l}6.86 \\
(4.91)\end{array}$ & $\begin{array}{c}0.376^{* * * *} \\
(0.000)\end{array}$ & $\begin{array}{c}0.373 * * * \\
(0.000)\end{array}$ & $\begin{array}{c}0.413 * * * \\
(0.000)\end{array}$ & $\begin{array}{c}0.416^{* * * *} \\
(0.000)\end{array}$ & $\begin{array}{c}0.438 * * * \\
(0.000)\end{array}$ \\
\hline $\begin{array}{l}\text { Proficiency in language of } \\
\text { instruction /foreign language }(1= \\
\text { low, } 5=\text { high })\end{array}$ & $\begin{array}{l}2.93 \\
(1.32)\end{array}$ & $\begin{array}{c}0.380 * * * \\
(0.000)\end{array}$ & $\begin{array}{c}0.391 * * * \\
(0.000)\end{array}$ & $\begin{array}{c}0.358 * * * \\
(0.000)\end{array}$ & $\begin{array}{c}0.341 * * * \\
(0.000)\end{array}$ & $\begin{array}{c}0.418 * * * \\
(0.000)\end{array}$ \\
\hline $\begin{array}{l}\text { Manager's level of expertise }(9= \\
\text { low, } 45=\text { high })\end{array}$ & $\begin{array}{l}30.69 \\
(7.61)\end{array}$ & $\begin{array}{c}0.584 * * * \\
(0.000)\end{array}$ & $\begin{array}{c}0.513 * * * \\
(0.000)\end{array}$ & $\begin{array}{c}0.573 * * * \\
(0.000)\end{array}$ & $\begin{array}{c}0.563 * * * \\
(0.000)\end{array}$ & $\begin{array}{c}0.612 * * * \\
(0.000)\end{array}$ \\
\hline Age of firm (years) & $\begin{array}{c}7.54 \\
(5.03)\end{array}$ & $\begin{array}{c}0.401 * * * \\
(0.000)\end{array}$ & $\begin{array}{c}0.399 * * * \\
(0.000)\end{array}$ & $\begin{array}{c}0.509 * * * \\
(0.000)\end{array}$ & $\begin{array}{c}0.499 * * * \\
(0.000)\end{array}$ & $\begin{array}{c}0.481 * * * \\
(0.000)\end{array}$ \\
\hline Number of full time employees & $\begin{array}{c}5 \\
(3.41)\end{array}$ & $\begin{array}{c}0.374 * * * \\
(0.000)\end{array}$ & $\begin{array}{c}0.374 * * * \\
(0.000)\end{array}$ & $\begin{array}{c}0.359 * * * \\
(0.000)\end{array}$ & $\begin{array}{c}0.325 * * * \\
(0.000)\end{array}$ & $\begin{array}{c}0.405 * * * \\
(0.000)\end{array}$ \\
\hline $\begin{array}{l}\text { Capital investments }(000,000 \mathrm{Tz} \\
\text { shillings })\end{array}$ & $\begin{array}{r}26.94 \\
(51.81)\end{array}$ & $\begin{array}{c}0.559 * * * \\
(0.000)\end{array}$ & $\begin{array}{c}0.505 * * * \\
(0.000)\end{array}$ & $\begin{array}{c}0.518 * * * \\
(0.000)\end{array}$ & $\begin{array}{c}0.528 * * * \\
(0.000)\end{array}$ & $\begin{array}{c}0.545 * * * \\
(0.000)\end{array}$ \\
\hline $\begin{array}{l}\text { Formalization status }(4=\text { low, } \\
20=\text { high })\end{array}$ & $\begin{array}{l}13.14 \\
(3.60)\end{array}$ & $\begin{array}{c}0.525 * * * \\
(0.000)\end{array}$ & $\begin{array}{c}0.502 * * * \\
(0.000)\end{array}$ & $\begin{array}{c}0.562 * * * \\
(0.000)\end{array}$ & $\begin{array}{c}0.522 * * * \\
(0.000)\end{array}$ & $\begin{array}{c}0.571 * * * \\
(0.000)\end{array}$ \\
\hline Total number of product varieties & $\begin{array}{l}6.61 \\
(1.92)\end{array}$ & $\begin{array}{l}-0.076 \\
(0.251)\end{array}$ & $\begin{array}{c}-0.161 * * \\
(0.015)\end{array}$ & $\begin{array}{l}-0.079 \\
(0.233)\end{array}$ & $\begin{array}{l}-0.069 \\
(0.301)\end{array}$ & $\begin{array}{l}-0.084 \\
(0.205)\end{array}$ \\
\hline $\begin{array}{l}\text { Access to production inputs } \\
\text { (average score; } 1=\text { low, } 5=\text { high) }\end{array}$ & $\begin{array}{l}4.15 \\
(0.75)\end{array}$ & $\begin{array}{c}0.317 * * * \\
(0.000)\end{array}$ & $\begin{array}{c}0.294 * * * \\
(0.000)\end{array}$ & $\begin{array}{c}0.324 * * * \\
(0.000)\end{array}$ & $\begin{array}{c}0.298 * * * \\
(0.000)\end{array}$ & $\begin{array}{c}0.323 * * * \\
(0.000)\end{array}$ \\
\hline $\begin{array}{l}\text { Access to information on raw } \\
\text { materials }(1=\text { low, } 5=\text { high })\end{array}$ & $\begin{array}{l}4.34 \\
(0.94)\end{array}$ & $\begin{array}{c}0.225 * * * \\
(0.001)\end{array}$ & $\begin{array}{c}0.184 * * * \\
(0.006)\end{array}$ & $\begin{array}{l}0.138 * * \\
(0.038)\end{array}$ & $\begin{array}{l}0.132 * * \\
(0.049)\end{array}$ & $\begin{array}{c}0.192 * * * \\
(0.004)\end{array}$ \\
\hline Self-financed firms (dummy) & $\begin{array}{l}0.27 \\
(0.45)\end{array}$ & $\begin{array}{c}-0.300^{* * * *} \\
(0.000)\end{array}$ & $\begin{array}{c}-0.303 * * * \\
(0.000)\end{array}$ & $\begin{array}{c}-0.266^{* * * *} \\
(0.000)\end{array}$ & $\begin{array}{c}-0.277 * * * \\
(0.000)\end{array}$ & $\begin{array}{c}-0.310^{* * * *} \\
(0.000)\end{array}$ \\
\hline Input availability (average score) & $\begin{array}{l}4.12 \\
(0.81)\end{array}$ & $\begin{array}{c}0.213 * * * \\
0.001\end{array}$ & $\begin{array}{c}0.191 * * * \\
0.004\end{array}$ & $\begin{array}{c}0.224 * * * \\
0.001\end{array}$ & $\begin{array}{c}0.193 * * * \\
0.004\end{array}$ & $\begin{array}{c}0.220 * * * \\
0.001\end{array}$ \\
\hline $\begin{array}{l}\text { Infrastructure_(availability of } \\
\text { power supply) ( } 1=\text { low, } 5=\text { high })\end{array}$ & $\begin{array}{l}4.40 \\
(0.73)\end{array}$ & $\begin{array}{l}0.123^{*} \\
(0.064)\end{array}$ & $\begin{array}{l}0.028 \\
(0.675)\end{array}$ & $\begin{array}{l}0.002 \\
(0.979)\end{array}$ & $\begin{array}{l}0.032 \\
(0.634)\end{array}$ & $\begin{array}{l}0.072 \\
(0.278)\end{array}$ \\
\hline $\begin{array}{l}\text { Infrastructure - availability of phone } \\
\text { services }(1=\text { low, } 5=\text { high })\end{array}$ & $\begin{array}{l}4.36 \\
(0.80)\end{array}$ & $\begin{array}{l}0.095 \\
(0.153)\end{array}$ & $\begin{array}{l}0.018 \\
(0.786)\end{array}$ & $\begin{array}{l}0.016 \\
(0.806)\end{array}$ & $\begin{array}{l}-0.039 \\
(0.566)\end{array}$ & $\begin{array}{l}0.067 \\
(0.316)\end{array}$ \\
\hline $\begin{array}{l}\text { Infrastructure - continuous and } \\
\text { uninterrupted electricity supply } \\
(1=\text { low, } 5=\text { high })\end{array}$ & $\begin{array}{c}3.11 \\
(1.25)\end{array}$ & $\begin{array}{c}0.338 * * * \\
(0.000)\end{array}$ & $\begin{array}{c}0.263 * * * \\
(0.000)\end{array}$ & $\begin{array}{c}0.278 * * * \\
(0.000)\end{array}$ & $\begin{array}{c}0.252 * * * \\
(0.000)\end{array}$ & $\begin{array}{c}0.328 * * * \\
(0.000)\end{array}$ \\
\hline
\end{tabular}

Continues on the next page..... 


\begin{tabular}{|c|c|c|c|c|c|c|}
\hline \multirow[b]{2}{*}{ Variables } & \multirow[b]{2}{*}{$\overline{\mathrm{x}}(\mathrm{s})$} & \multicolumn{4}{|c|}{$\begin{array}{l}\text { STM practices } \\
\text { correlation (sig. 2-tailed) }\end{array}$} & \multirow[b]{2}{*}{$\begin{array}{l}\text { Total } \\
\text { STM }\end{array}$} \\
\hline & & $\begin{array}{l}\text { Environm } \\
\text { ental } \\
\text { analysis }\end{array}$ & $\begin{array}{l}\text { Strategy } \\
\text { planning }\end{array}$ & $\begin{array}{l}\text { Strategy } \\
\text { implementa } \\
\text { tion }\end{array}$ & $\begin{array}{l}\text { Strategy } \\
\text { control }\end{array}$ & \\
\hline $\begin{array}{l}\text { Infrastructure - continuous and } \\
\text { uninterrupted water supply ( } 1= \\
\text { low, } 5=\text { high })\end{array}$ & $\begin{array}{c}3.21 \\
(1.25)\end{array}$ & $\begin{array}{c}0.242 * * * \\
(0.000)\end{array}$ & $\begin{array}{l}0.204 * * * \\
(0.002)\end{array}$ & $\begin{array}{c}0.186^{* * * *} \\
(0.005)\end{array}$ & $\begin{array}{c}0.194 * * * \\
(0.003)\end{array}$ & $\begin{array}{c}0.238^{* * * *} \\
(0.000)\end{array}$ \\
\hline $\begin{array}{l}\text { Distance from production facility to } \\
\text { main road }(\mathrm{km})\end{array}$ & $\begin{array}{l}4.81 \\
(10.9)\end{array}$ & $\begin{array}{l}0.000 \\
(0.996)\end{array}$ & $\begin{array}{l}0.058 \\
(0.417)\end{array}$ & $\begin{array}{l}0.045 \\
(0.527)\end{array}$ & $\begin{array}{l}0.100 \\
(0.166)\end{array}$ & $\begin{array}{l}0.049 \\
(0.494)\end{array}$ \\
\hline $\begin{array}{l}\text { Access to the main road - travel } \\
\text { time from production facility to } \\
\text { main road (Mins) }\end{array}$ & $\begin{array}{l}34.39 \\
(130)\end{array}$ & $\begin{array}{c}0.045 \\
(0.532)\end{array}$ & $\begin{array}{l}0.095 \\
(0.186)\end{array}$ & $\begin{array}{c}0.087 \\
(0.225)\end{array}$ & $\begin{array}{l}0.115 \\
(0.109)\end{array}$ & $\begin{array}{l}0.096 \\
(0.179)\end{array}$ \\
\hline $\begin{array}{l}\text { Distance from production facility to } \\
\text { the nearest major market }(\mathrm{km})\end{array}$ & $\begin{array}{l}4.03 \\
(10.6)\end{array}$ & $\begin{array}{l}0.167 * * \\
(0.017)\end{array}$ & $\begin{array}{l}0.140^{* *} \\
(0.044)\end{array}$ & $\begin{array}{l}0.163^{* * *} \\
(0.019)\end{array}$ & $\begin{array}{l}0.118^{*} \\
(0.093)\end{array}$ & $\begin{array}{c}0.186^{* * * *} \\
(0.007)\end{array}$ \\
\hline $\begin{array}{l}\text { Electricity availability (number of } \\
\text { interruptions per month) }\end{array}$ & $\begin{array}{r}4.40 \\
(5.44)\end{array}$ & $\begin{array}{l}-0.067 \\
(0.323)\end{array}$ & $\begin{array}{l}-0.063 \\
(0.354)\end{array}$ & $\begin{array}{l}-0.065 \\
(0.336)\end{array}$ & $\begin{array}{l}-0.002 \\
(0.978)\end{array}$ & $\begin{array}{l}-0.090 \\
(0.185)\end{array}$ \\
\hline $\begin{array}{l}\text { Bureaucracy- number of incidences } \\
\text { of changes in business regulations } \\
\text { per year }\end{array}$ & $\begin{array}{c}1.65 \\
(1.95)\end{array}$ & $\begin{array}{c}0.244 * * * \\
(0.001)\end{array}$ & $\begin{array}{l}0.159 * * \\
(0.038)\end{array}$ & $\begin{array}{l}0.262 * * * \\
(0.001)\end{array}$ & $\begin{array}{c}0.282 * * * \\
(0.000)\end{array}$ & $\begin{array}{c}0.254 * * * \\
(0.001)\end{array}$ \\
\hline $\begin{array}{l}\text { Convenience of the business license } \\
\text { procedure ( } 1=\text { poor, } 5=\text { excellent) }\end{array}$ & $\begin{array}{l}3.43 \\
(0.99)\end{array}$ & $\begin{array}{c}0.199 * * * \\
(0.003)\end{array}$ & $\begin{array}{c}0.196 * * * \\
(0.003)\end{array}$ & $\begin{array}{c}0.235^{* * * *} \\
(0.000)\end{array}$ & $\begin{array}{c}0.191 * * * \\
(0.004)\end{array}$ & $\begin{array}{c}0.228 * * * \\
(0.000)\end{array}$ \\
\hline $\begin{array}{l}\text { Bureaucracy - average number of } \\
\text { days from initial application to } \\
\text { approval }\end{array}$ & $\begin{array}{l}10.76 \\
(11.4)\end{array}$ & $\begin{array}{l}-0.098 \\
(0.175)\end{array}$ & $\begin{array}{l}-0.073 \\
(0.309)\end{array}$ & $\begin{array}{l}-0.074 \\
(0.301)\end{array}$ & $\begin{array}{l}-0.063 \\
(0.379)\end{array}$ & $\begin{array}{l}-0.109 \\
(0.130)\end{array}$ \\
\hline $\begin{array}{l}\text { Increase in sales (average } 3 \text { year } \\
\text { trend; } 1=\text { decrease }, 5=\text { increase) }\end{array}$ & $\begin{array}{l}3.61 \\
(0.84)\end{array}$ & $\begin{array}{c}0.531 * * * \\
(0.000)\end{array}$ & $\begin{array}{c}0.523 * * * \\
(0.000)\end{array}$ & $\begin{array}{c}0.532 * * * \\
(0.000)\end{array}$ & $\begin{array}{c}0.535 * * * \\
(0.000)\end{array}$ & $\begin{array}{c}0.559^{* * * *} \\
(0.000)\end{array}$ \\
\hline $\begin{array}{l}\text { Increase in expenses (average } 3 \\
\text { year trend; } 1=\text { decrease , } 5=\text { increase) }\end{array}$ & $\begin{array}{l}3.78 \\
(0.66)\end{array}$ & $\begin{array}{l}0.123 * \\
(0.063)\end{array}$ & $\begin{array}{c}0.095 \\
(0.152)\end{array}$ & $\begin{array}{c}0.172 * * * \\
(0.009)\end{array}$ & $\begin{array}{l}0.144^{* *} \\
(0.030)\end{array}$ & $\begin{array}{l}0.131^{* *} \\
(0.048)\end{array}$ \\
\hline $\begin{array}{l}\text { Increase in number of workers } \\
\text { (average } 3 \text { year trend; } 1=\text { decrease, } \\
5=\text { increase) }\end{array}$ & $\begin{array}{l}3.13 \\
(0.55)\end{array}$ & $\begin{array}{l}-0.086 \\
(0.197)\end{array}$ & $\begin{array}{l}-0.066 \\
(0.319)\end{array}$ & $\begin{array}{l}-0.035 \\
(0.596)\end{array}$ & $\begin{array}{l}-0.093 \\
(0.166)\end{array}$ & $\begin{array}{l}-0.079 \\
(0.236)\end{array}$ \\
\hline
\end{tabular}

Notes:

Spearman rho correlation, (r) Sig. 2-tailed test, significance at *** $\mathrm{p}<0.01 ; * * \mathrm{p}<0.05$ and $* \mathrm{p}<$ 0.1 .

Strength of correlation between variables: small $(\mathrm{r}=0.10)$ medium $(\mathrm{r}=0.30$ to 0.49$)$ and large $(\mathrm{r}=0.50$ to 1.00$)$.

$\overline{\mathrm{x}}(\mathrm{s})$ - sample mean (standard deviation) 


\section{Appendix 1-2: Study Area}

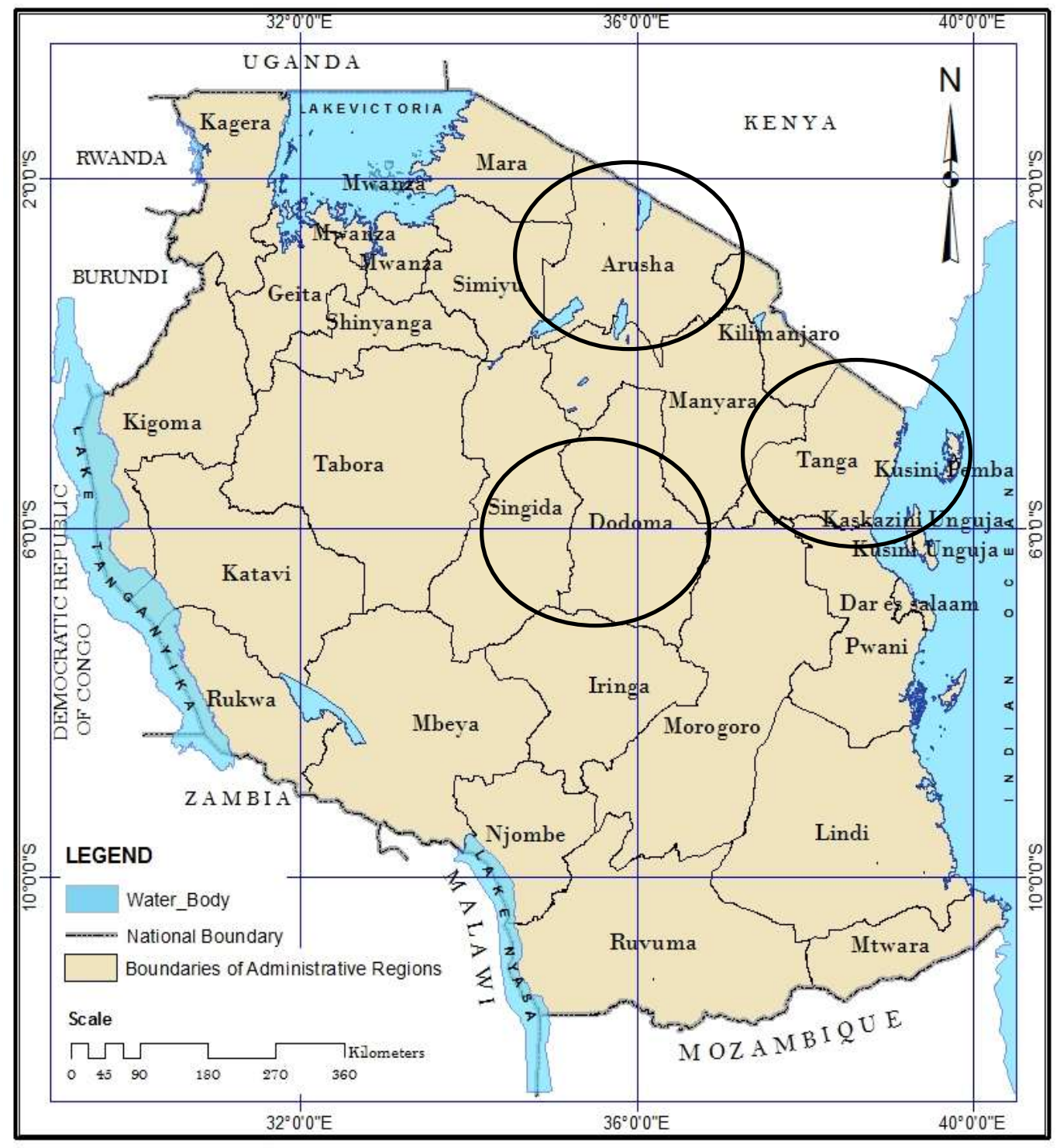




\title{
Chapter Two
}

\section{The Impact of External and Internal Factors on Strategic Management Practices of Agribusiness Firms in Tanzania}

Theresia Dominic and Ludwig Theuvsen

\begin{abstract}
All firms need to work out strategic plans to exploit the existing market, but they differ in their capacity to implement and manage strategies. Considering the industrial organization and resource-based views in the strategic management literature, we understand that firm attributes, resources and external environmental factors are critical links to strategic practices. With regard to African agribusiness firms, there is scant research on how these factors determine the successful application of strategic management practices. Therefore, this study uses empirical data from 229 agribusiness firms in Tanzania to obtain insights into the determinants of their choice of strategic management practices. The results show significantly that better strategic actions reside in the capabilities of firm managers, whereas many external factors, such as access to public infrastructure, did not turn out to have a significant influence. The findings have interesting implications for the management of agribusiness firms in African countries and other developing and emerging economies.
\end{abstract}

This paper has been published in this similar version as a discussion paper within the Global Food Discussion Paper Series. 


\subsection{Introduction}

Competitiveness in global markets has required firms to think, plan and make decisions strategically. In this case a series of practices such as environmental analysis, strategy formulation, implementation, evaluation and control of strategic plans within firms are applied through strategic management (STM) approaches (Wheelen \& Hunger, 2006). Strategic management consists of actions that provide a framework for the longterm development of a company and result in the achievement of a firm's objectives (Hitt, Ireland, \& Hoskisson, 2009). Various studies have revealed that small and medium-sized firms differ from large companies with regard to their strategic management practices (Welsh \& White, 1981) and often lack strategic awareness (Gibb $\&$ Scott, 1985). Several studies of small firms have attempted to link STM and firm performance (R. Andrews et al., 2006; Beaver, 2002; Bracker \& Pearson, 1986; Chen, 2005; Georgellis et al., 2000; Stacey, 2011). Schwenk and Shrader (1993) examined 14 research studies and showed a positive, significant link between the planning activities of small firms and their performance. However, success depends on who carries out the planning in a given firm and a proper assessment of the firm's resources and environmental conditions (Stacey, 2011). Since relatively few agribusiness studies discuss firms' strategic management practices, this study seeks to fill that gap by examining STM application in food processing firms (Trienekens, 2011). Greater attention is needed to 'strategic management' explanations of agribusiness firms (Mugera, 2012; Ng and Siebert, 2009) especially in the context of developing and emerging economies since companies from these economies have only rarely been addressed by strategic management research.

STM practices are sometimes considered less relevant for small and medium-sized firms, especially in the agribusiness sector, because it is thought that a systematic STM is necessary only for large corporations (Chen, 2005; Fard et al. 2011; Hitt et al., 2009). In this regard, small firms end up having poor plans on how to get their products to final consumers in food markets (Admassie \& Matambalya, 2002; Kinda \& Loening, 2010). But in many countries food markets are characterized by a high intensity of competition and increasing internationalization (Rama, 2005; Theuvsen et al., 2010). Theoretically, this means that the firms facing the hardship in the market environment will require more strategic practices than those facing simple environments (Miller \& Friesen, 1983) - 
regardless of their size. Furthermore, firms in competitive environments should be proactive, foresee changes in their environment and refine their strategies according to market requirements (Sull, 2009).

In Tanzania and other developing and emerging economies, food processing firms have great potential for growth, and their strategic management orientation is progressing. However, despite some progress, strategic management is still in its infancy in many companies and our current understanding of their operating strategies has remained limited. Several explanations are offered for firms' reluctance to implement strategic management practices, including lack of better trading strategies and poor managerial skills (Dinh et al., 2013). Over the years government programs such as the Tanzanian Agricultural Sector Development Program 2006-2013, have been formulated to support the building of better functioning agro processing firms (Dinh et al., 2013). However, firms' abilities to develop their own strategies differ and are not well understood. Some firms are better at implementing management practices than others. Therefore, our research question is this: What is the influence of internal and external factors on the successful implementation of a firm's strategic management practices? The factors investigated here are firm characteristics, its access to resources and the external pressures on the firm from its operating environment.

The remainder of this paper is structured as follows: In Section 2 we clarify the foundation behind specific relationships between various contingency factors and management practices through giving a theoretical background and building a conceptual framework. We also generate research assumptions based on different arguments from the empirical literature. Section 3 describes the sample, measures and analytical techniques. Then results are presented in Section 4, including primary data from interviews with agribusiness firm managers. Finally, in Section 5 we discuss the conclusions and implications of the results and give directions for future research.

\subsection{Theoretical Framework and Hypotheses}

Due to market competition and other external challenges, firms make efforts to carry out systematic planning and decision making. Strategic management is a management practice that can contribute to these efforts. It contains a full set of actions required for a firm to analyze its external and internal environments; formulate its 
corporate, competitive and functional strategies (Hofer \& Schendel, 1978); achieve strategic competitiveness; and earn above-average returns (Hitt et al., 2009). The concept demonstrates why some firms consistently perform better while others fail to do so (Nutt, 2004). Furthermore, in their effort to perform better, firms engage with STM practices in order to achieve their objectives and hence satisfy those interest groups which are affected by the achievement of the firm's objectives (according to the stakeholder theory [Freeman, 2010]).

With regard to the relationship between strategic management practices and firm performance, two theoretical strands in the strategic management literature can be distinguished. The first theory - the industrial organization model of above average returns, or I/O theory - suggests that the external environment is the primary determinant of firms' strategic actions (see, for instance, Porter 1980). The environment is assumed to impose pressure and constraints that determine the strategies resulting in the achievement of firm objectives. The key to this theory is identifying these determinants, tailoring strategies accordingly and competing successfully (Collis, 1991). This perspective has also been applied to the analysis of strategic management in the agribusiness sector, including small and medium-sized firms (Niederhut-Bollmann \& Theuvsen, 2008).

The second theory - the resource based theory (RBT) in strategic managementviews internal organizational resources as the key determinants of strategy and performance, suggesting that a firm's unique resources and capabilities are the critical links to strategic management practices. According to Barney (1991) and Barney and Hesterly (2010), firms must be organized to take advantage of their resources and capabilities in order to remain competitive and realize their potential. With regard to agribusinesses, RBT has not been widely used to explain the differences in performance with regard to small agribusiness firms. Therefore, as suggested by Mugera (2012), there is a need to apply it in agribusiness studies to come up with more in-depth analyses of resources and capabilities that enhance better strategic management practices and hence performance.

Thus, to engage in STM practices, such as formulating mission and vision statements and planning and implementing strategies, firms use both the industrial organization and resource-based views. The first strand of strategic management theory is concerned with the firm's external environment, which sets the scene for strategic 
decisions, while the second theory focuses on the firm's internal environment, i.e., its tangible, intangible and human resources and its capabilities (Hitt et al., 2009). Furthermore, no single strategy would be appropriate for all firms operating in a particular type of environment; rather, the choice of strategies depends on individual firm characteristics, a firm's environment and available resources and capabilities (Grant, 2013).

For the purpose of identifying research gaps, we review studies that have been conducted in relation to the determinants of STM practices, mainly firm characteristics, firm resources and external factors. We also explain studies on firm performance in relation to STM practices to develop the theoretical framework underlying this study.

\subsubsection{Firm Characteristics}

STM implementation is affected by several firm characteristics, including size, output, sales growth and profitability (Heyder and Theuvsen 2008). The variations of each can affect the choice of STM practices and eventually the overall firm performance. Fajnzylber et al. (2006) analyze variation in firm age and managers' experience, concluding that strategic performance tends to decline as a firm ages because, when a new practice is introduced, younger firms more easily adopt it, while for older firms it may be costly to let go of old strategies and work procedures. Others disagree, saying that old firms easily adapt to new practices due to the staff's greater degree of experience (Hitt et al., 2009). Experienced staff can enhance knowledge transfer from previous strategic challenges (Gary et al., 2012) and hence engage in more adequate strategic practices.

On the matter of firm size, Weinrauch et al. (1991) argue that small firms lack a strategic orientation compared to larger ones and that bigger firms are presumed to be relatively more efficient than smaller ones. In contrast, Coviello et al. (2000) claim that small firms actually have a more strategic orientation because they are driven to develop strategic planning processes as they grow in size, scope and resource base. Furthermore, some studies indicate that firm size does not appear to influence how firms plan their strategies (Miles et al., 2000), but Bigsten and Gebreeyesus (2007) observed that smaller, younger firms are more strategic since they grow faster than larger, older firms. 
Another characteristic is degree of formalization, i.e., the extent of written rules, procedures and instructions in a firm (Adler \& Borys, 1996), or, more specifically, formality, i.e., the official status of a firm, for instance, for the purpose of paying taxes (McKenzie \& Sakho, 2010). There is empirical evidence that firms with a high level of formalization show better application of STM practices, higher revenues or better performance (Fajnzylber et al., 2006; McKenzie and Sakho, 2007). However, Bigsten et al. (2004) identified no significant difference in achieving productivity strategy between small formal and informal firms. Earlier studies described efficient formal organizations as those with a clear division of work and a clear structure of command (Fayol, 1921); recent studies focusing on small businesses indicate the same but with more focus on abiding by business regulations, other written rules, etc. (Robbins \& Judge, 2012). Many developing countries recognize the importance of small businesses in economic growth and hence tolerate informal business structures because the informal sector reduces unemployment (Nelson \& DeBruijn, 2005). However, regardless of whether these firms operate formally or informally, it is not clear whether they are able to conduct STM practices. Based on these arguments on size, age and formality status, we hypothesize the following:

$H_{1}$ : Firms' distinguishing characteristics have significant effects on successful application of STM practices.

$H_{1 a}:$ The older the firm is, the more common is the application of STM practices.

$H_{1 b}$ : Increase in firm size is associated with increase in the application of STM practices.

$H_{1 c}:$ The formalization status of a firm has a positive effect on its application of STM practices.

\subsubsection{Firm's Resources and Capabilities}

Firms' ability to achieve their objectives is closely related to the resources they possess and how they are managed (Bloom \& Van Reenen, 2007). Firm resources facilitate successful implementation of strategies as long as they are valuable, rare, imperfectly imitable and imperfectly substitutable (Penrose, 1959; Mugera, 2012). Availability and management of valuable resources facilitate better strategic practices. However, Ferrier (2001) proposed an opposing explanation by arguing that a lack of resources will actually cause aggressive strategic practices by the firms, as they struggle 
to compete to acquire resources; but there are limited studies to support this argument. With reference to resource-based theory as explained earlier, our study looks at helpful resources such as tangible and intangible possessions that are controlled and invested by the firm to implement strategies and attain and sustain competitiveness (Barney, 1991). The small firms' strategic actions are often affected by their low investment capacity due to their tendency to use unsustainable sources of finance, such as their own savings, money from local lenders, or loans from family and friends (Dinh et al., 2013). Hence, low investment might pose a challenge when applying STM practices. Access to market information is also an important factor for STM, especially when conducting environmental analyses (Hitt et al., 2009).

The most discussed resource for large firms is managers' level of expertise. Expertise is associated with better application of strategic management practices as discussed by Boehlje et al. (2011). The authors analyzed the consequences of strategic uncertainty for the agribusiness firm and indicated that managers should be able to reassess the firm's strategy. If firm managers have limited business ability, they will not be able to resolve their firms' strategic positions (Ambrosini \& Bowman, 2009; Mugera, 2012). However, the authors do not specify which expertise works best for small firm operations. Also, there are insufficient programs to help small agribusiness firm owners to improve their skills. More attention has been devoted to seeking external sources of funds, while the issue of managerial expertise has been neglected (Kweka \& Fox, 2011). Based on these arguments concerning firm's investment level, access to market information and managers' level of expertise, we hypothesize the following:

$\mathrm{H}_{2}$ : Changes in firms' access to internal resources and capabilities are associated with an increase or decrease in the application of STM practices.

$\mathrm{H}_{2 \mathrm{a}}$ : An increase in firms' investment level is associated with an increase in the application of STM practices.

$\mathrm{H}_{2 \mathrm{~b}}$ : The more firms have access to market information, the more they apply STM practices.

$\mathrm{H}_{2 \mathrm{c}}$ : An increase in managers' expertise is associated with an increase in the application of STM practices. 


\subsubsection{Pressure from the External Environmental}

A number of environmental factors are identified in several studies as determinants of firm strategies. Successful implementation of strategies depends on having adequate information on changing customers' needs, changing technology in one's industry and government regulations and on knowing what competitors are up to and what is occurring in the general economy both domestically and worldwide (Burke, 2011). The external environment of small firms is characterized by several constraints that affect a firm's ability to afford strategic operations (Dobbs \& Hamilton, 2007; Kweka \& Fox, 2011). Therefore, it is implied that those companies that face these constraints will have a hard time implementing and achieving their strategies. But Smallbone and Wyer (2006) argue that these constraints actually constitute a greater impetus for the firm to perform strategic practices.

For example, Dinh et al. (2013) indicate that unavailability of quality inputs can prevent firms' competitiveness. Better availability of raw agricultural products, food packages, tools, labels, etc., facilitates better strategic actions. Other studies identify specific factors that can benefit small firms, such as access to public infrastructure (e.g., electricity and public transport [Jin and Deininger 2008]), whereas in countries such as Tanzania, poor quality infrastructure causes marketing barriers (Kweka, 2006). Furthermore, in the external environment, access to funds (i.e., bank loans or grants) is a potential factor. Evidence shows that smaller firms with access to external funds are able to make strategic investment plans and grow more quickly than those relying on their own funds (Fafchamps \& Quinn, 2012). Therefore, availability of inputs, public infrastructure and access to funds may all have a significant influence on the implementation of firm strategies, simply because they pressurize the firms to develop new and better strategies in order to cope with external changes or may limit a firm's ability to act strategically. In this regard, we formulate the following hypothesis:

$H_{3}$ : Pressure from a firm's external environment will directly affect the application of STM practices.

$H_{3 a}:$ Better availability of inputs will directly affect the application of STM practices.

$H_{3 b}$ : Better access to better public infrastructure services will directly affect the application of STM practices. 
$H_{3 c}:$ Better access to external sources of funds will directly affect the application of STM practices.

\subsubsection{Strategic Management Practices}

Understanding the unique elements of small firms' STM practices in agribusiness is critical in this era of food market transformation (Bakker, 2011). Some studies have analyzed STM practices and discussed its pitfalls, but, as noted above, these studies have often concentrated on medium-sized and large corporations (Chen, 2005; Fard et al. 2011; Hitt et al., 2009; Stacey, 2011). For large organizations, the application of STM practices includes sophisticated application of various tools and procedures involving top management executives, professional managers such as planning specialists, other employees and external consultants and stakeholders. But when we study small firms (with capital of less than US\$125,000), we have to look at the very basic details of their ability to perform each step of STM practices as described by Wheelen and Hunger (2006):

(a) The preliminary step of STM practices includes environmental scanning; we assess whether firms are aware of their internal and external market environment or whether they are informed about potential opportunities of the firm, etc.

(b) We assess whether there are strategic plans that are listed in terms of firm objectives, in a specific time frame and if so, whether they are regularly updated and known to every employee in the firm.

(c) The following step involves strategy implementation; we assess whether firms have developed an operating manual for employees, have adequate number of workers who are committed to strategic management practices or whether they can finance these activities.

(d) The last step involves strategy evaluation; we assess whether the firms have a tendency to compare actual activities with original plans, have alternative plans in case of unexpected developments or regularly compare their firm's strategy with those of competitors. 
Even though strategic management practices may seem suitable at first sight, mainly for large corporate firms, there is a need to establish their relevance for small firms as well. Initially, there is a need to better understand which STM practices small firms actually apply and what determines the application of STM practices.

\subsubsection{Performance}

The study by Bakar et al. (2011) of STM application in business firms concluded that STM enables firms to increase their profit by increasing sales and reducing unnecessary expenses. It has repeatedly been argued that practices such as strategy planning and implementation serve the purpose of improving firm performance and that, hence, both constructs are closely linked (Andrews et al. 2009; Boyne and Walker 2004; Andrews Boyne, and Walker 2006; Beaver 2002; Bracker and Pearson 1986; Chen 2005; Georgellis, Joyce, and Woods 2000; Stacey, 2011). Moreover, Woods and Joyce (2003) indicated that firms that were using STM tools achieved rapid growth in performance. However, only a very limited number of studies apply to small agribusiness firms. Some studies that have examined these firms show that those companies which engage in strategic management practices do not do so mainly for reasons of reaching performance goals but for reasons of complying with public pressure and meeting stakeholders' expectations (Heyder and Theuvsen, 2012). Other studies have shown that for agribusiness firms to have a clear strategic position improves their performance (Theuvsen, Heyder, \& Niederhut-Bollmann, 2010).

Since specific routes to performance are many, varied and not susceptible to simple generalizations (Cooper et al., 2005), when determining the performance of food processors, we included a variety of questions on revenue growth and sales growth perceived by managers during the past three years, as used in Zhang and $\mathrm{Li}$ (2008), and trends in total expenses as used by Van Duren et al. (2003). We also looked at number of employees since the number can correlate highly with sales volume and growth (Beck et al., 2005; Zhang and Li, 2008) and achievement of strategies as possible measures of performance. We therefore propose the following hypothesis:

$\mathrm{H}_{4}$ : The greater the extent of strategic management practices, the better the firm's performance. 
To sum up our discussion from the literature, a conceptual framework underlying the empirical analyses (see Figure 2-1) is proposed.

Figure 2-1: Conceptual Framework

\section{Determinants}

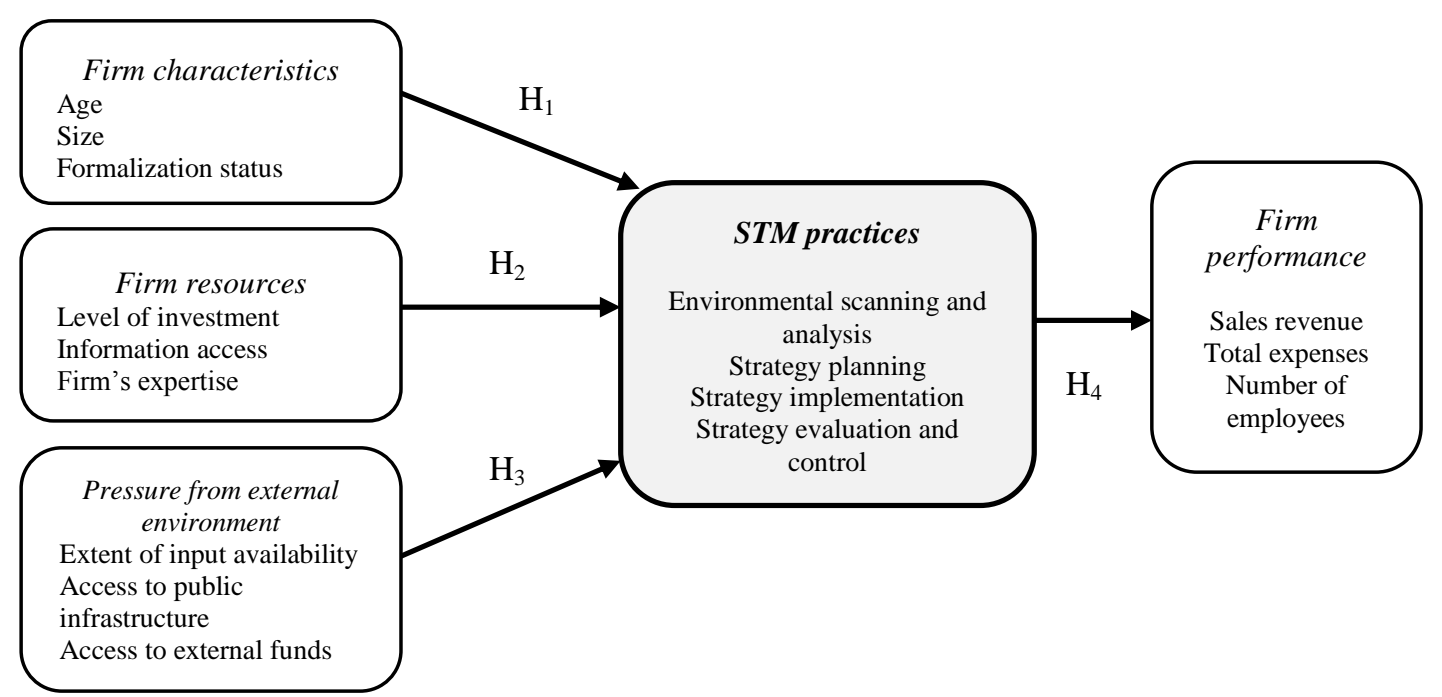

Source: Authors' illustration

\subsection{Methodology}

\subsubsection{Data collection and sample description}

The hypotheses and conceptual framework outlined above inspired an empirical study of strategic management practices in small Tanzanian agribusiness firms. Between May and August 2013, data was collected through interviews with firm owners and/or managers with the aid of a structured questionnaire. The sample consisted of firms processing cereals, vegetables and fruits located in the Arusha, Dodoma and Tanga regions of Tanzania. The selection of firms followed a random sampling technique from a list of processors in the Small Industries Development Organization (SIDO). SIDO is a parastatal organization for improving the effectiveness of small industries in the country. Over 331 firms were contacted and agreed to participate in the interviews; 229 questionnaires were qualified for analysis after excluding partially completed questionnaires. Sixty-two questionnaires were collected from Arusha, 105 from Dodoma and 62 from Tanga. 
The description of the sample is presented in Table 2-1. The firms have an average of $7 \frac{1}{2}$ years of business operations and process on average three types of food products: cereals, fruits and vegetables. The majority of the firms $(98.5 \%)$ buy farm produce from local farmers, and the rest (1.5\%) import produce from neighboring countries.

Table 2-1: Descriptive Information about the Sample (N=229)

\begin{tabular}{|c|c|c|c|c|}
\hline Variables & Mean & Std. Dev & Min & Max \\
\hline \multicolumn{5}{|l|}{ Information on Firm } \\
\hline Firm age (yrs.) & 7.54 & 5.03 & 3 & 28.58 \\
\hline Full-time employees & 5.00 & 3.41 & 3 & 20 \\
\hline Capital investment in million TZS & 26.94 & 51.81 & 0.3 & 350 \\
\hline Self-financed firms (dummy) & 0.27 & 0.40 & 0 & 1 \\
\hline Total number of products & 3.00 & 1.92 & 1 & 11 \\
\hline Non-perishable (dummy) & 0.66 & 0.48 & 0 & 1 \\
\hline Family business (dummy) & 0.26 & 0.44 & 0 & 1 \\
\hline \multicolumn{5}{|c|}{ Products: Cereals $(65.9 \%)$, fruits $(16.4 \%)$, vegetables $(11.5 \%)$, other $(6.2 \%)$} \\
\hline \multicolumn{5}{|l|}{ Information on Respondent } \\
\hline Age & 43.00 & 10.70 & 18 & 78 \\
\hline Years of education (yrs.) & 11.05 & 3.51 & 1 & 22 \\
\hline
\end{tabular}

The respondents in this study were those who were able to provide a general overview of the firm and the cornerstones of their strategies. Their ages ranged from 18 to 78 years (average: 43 years), with an average of 11.05 years of school education; 61 percent of the respondents were female

\subsubsection{Model Estimation}

Appendix 2-1 shows the variables and items used for building our model: latent variables (or constructs), items in each construct, means and standard deviations. The formal status of a firm is represented by four items, its access to information by eight items, managers' expertise by nine items, and size and age by one item each. Other constructs are level of investment, which has six items; access to public infrastructure (eight items); availability of inputs (two items); and access to external sources of funds (one item). However, items that loaded less than 0.5 were excluded. We use partial least squares structural equation modelling (PLS-SEM) through Smart PLS 2.0 M3 software to estimate our model. The software has the advantage of dealing with complex explorative models with multiple relationships. Also, our study model measures relationships between eleven constructs together with a mix of reflective, formative and single items, 
which can be easily handled without any identification problem by PLS-SEM (Haenlein and Kaplan, 2004; Hair et al., 2014).

We decided to build a hierarchical component model (HCM) and calculate coefficients by using a repeated indicator approach. The approach involves testing second order structures that contain two layers of constructs; this means that items (indicators) used in the first layer are repeated in a second layer. These variables are firm resources (Rs) and pressure from the external environment (EXT); using only two such variables means that the model will have fewer exogenous constructs, thus reducing the number of relationships in the structural model and making the path model easier to grasp.

\subsubsection{Quality Assessment of the Model}

We proceed by testing the reliability of our outer model (mode A) through composite reliability (CR) score and construct convergent validity through average variance extracted (AVE) scores and discriminant validity using the Fornell-Larcker criterion as applied in Henseler et al. (2009). Table 2-2, Table 2-3 and Table 2-4 show that all items are reliable, with CR scores above the threshold value of 0.708 . Also, all measures of AVE for the first order constructs are above 0.5, which means that the latent variable on average explains more than $50 \%$ of the variance in the measured variables; hence, convergent validity is met.

Convergent validity for the second order constructs 'firm resources' and 'pressure from external environment' show AVE values of 0.462 and 0.43 respectively. The first value is below the threshold of 0.5 but quite close to this threshold. The latter value of 0.43 for the second order construct is not close to the threshold; but its first order constructs (i.e. 'INPUT' and 'INFRA') have their AVE values above the threshold (Table 2-4) hence we will keep the variable in the model. 
Table 2-2: Quality Criteria for Firm Characteristics Constructs

\begin{tabular}{|c|c|c|c|c|c|c|}
\hline Variable & Construct & & Loadings & AVE & $\mathbf{C R}$ & Cronbach $\alpha$ \\
\hline AGE & Age of the firm (AGE) & 1 item & 1 & & & 1 \\
\hline SIZE & Size of the firm (SIZE) & 1 item & 1 & & & 1 \\
\hline FORMAL & Formalization status (Xs) & 4 items & & 0.734 & 0.917 & 0.879 \\
\hline FORM_l & \multicolumn{2}{|c|}{$\begin{array}{l}\text { You have a picture of an organization } \\
\text { structure. }\end{array}$} & 0.84 & & & \\
\hline FORM_2 & \multicolumn{2}{|c|}{$\begin{array}{l}\text { You have indicated clearly the division } \\
\text { of work for employees. }\end{array}$} & 0.91 & & & \\
\hline FORM_3 & \multirow{2}{*}{\multicolumn{2}{|c|}{$\begin{array}{l}\text { You have written a clear business plan. } \\
\text { You are able to abide to all legal business } \\
\text { regulations. }\end{array}$}} & 0.85 & & & \\
\hline FORM_4 & & & 0.82 & & & \\
\hline
\end{tabular}

Table 2-3: Quality Criteria for Reflective First Order Constructs of Firms' Internal Resources

\begin{tabular}{|c|c|c|c|c|c|}
\hline Variable & Construct & Loadings & AVE & CR & Cronbach $\alpha$ \\
\hline INVEST & Investment level: & & 0.81 & 0.90 & 0.758 \\
\hline INVEST 1 & How much have you invested on the firm's buildings? & 0.91 & & & \\
\hline INVEST_2 & $\begin{array}{l}\text { How much have you invested on the firm's motor } \\
\text { vehicle? }\end{array}$ & 0.89 & & & \\
\hline INFO & Information Access & & 0.66 & 0.85 & 0.743 \\
\hline INFO_1 & Information on where to get raw materials & 0.73 & & & \\
\hline$I N F O \_2$ & Information access on changes in product prices & 0.87 & & & \\
\hline INFO_3 & Information access on where to sell & 0.83 & & & \\
\hline EXP & Manager's level of expertise & & 0.63 & 0.94 & 0.926 \\
\hline EXP_l & Level of expertise in bookkeeping and accounting & 0.73 & & & \\
\hline$E X P \_2$ & Level of expertise in managing employees & 0.81 & & & \\
\hline$E X P-3$ & Level of expertise in marketing techniques & 0.79 & & & \\
\hline EXP 4 & Level of expertise in financial management & 0.83 & & & \\
\hline EXP 5 & Level of expertise in stock taking and record keeping & 0.82 & & & \\
\hline EXP_6 & Level of expertise in food quality and safety standards & 0.78 & & & \\
\hline EXP_7 & Level of expertise in customer care & 0.81 & & & \\
\hline$E X P \_8$ & Level of expertise in product presentation & 0.78 & & & \\
\hline EXP_9 & Level of expertise in food processing & 0.79 & & & \\
\hline
\end{tabular}

Table 2-4: Quality Criteria for the Reflective First Order Constructs of 'Pressure from Firm's External Environment' Variable

\begin{tabular}{|c|c|c|c|c|c|}
\hline Variable & Construct & Loadings & AVE & CR & $\begin{array}{r}\text { Cronbach } \\
0\end{array}$ \\
\hline INPUT & Input availability & & 0.68 & 0.81 & 0.537 \\
\hline$I N P U T \_1$ & Availability of agricultural inputs & 0.84 & & & \\
\hline INPUT_2 & Availability of non-agricultural inputs & 0.81 & & & \\
\hline INFRA & Access to public infrastructure level & & 0.68 & 0.86 & 0.748 \\
\hline INFRA_2 & The firm is in the city center. & 0.62 & & & \\
\hline INFRA_7 & $\begin{array}{l}\text { There is a continuous and uninterrupted } \\
\text { electricity supply. }\end{array}$ & 0.91 & & & \\
\hline INFRA_8 & $\begin{array}{l}\text { There is a continuous and uninterrupted } \\
\text { water supply. }\end{array}$ & 0.91 & & & \\
\hline FUNDS & $\begin{array}{l}\text { Access to funds (FUNDS) (single item } \\
\text { excluded from HCM) }\end{array}$ & 1 & & & 1 \\
\hline
\end{tabular}


We use the Fornell-Larcker criterion to check for discriminant validity. The aim is to see whether a construct shares more variance with its measure than it shares with other constructs in a given model. The criterion is met when the AVE scores (see diagonal values in Table 2-5) of each latent construct is higher than the construct's highest squared correlation with any other latent construct (Fornell \& Larcker, 1981).

\section{Table 2-5: Fornell-Larcker Criteria}

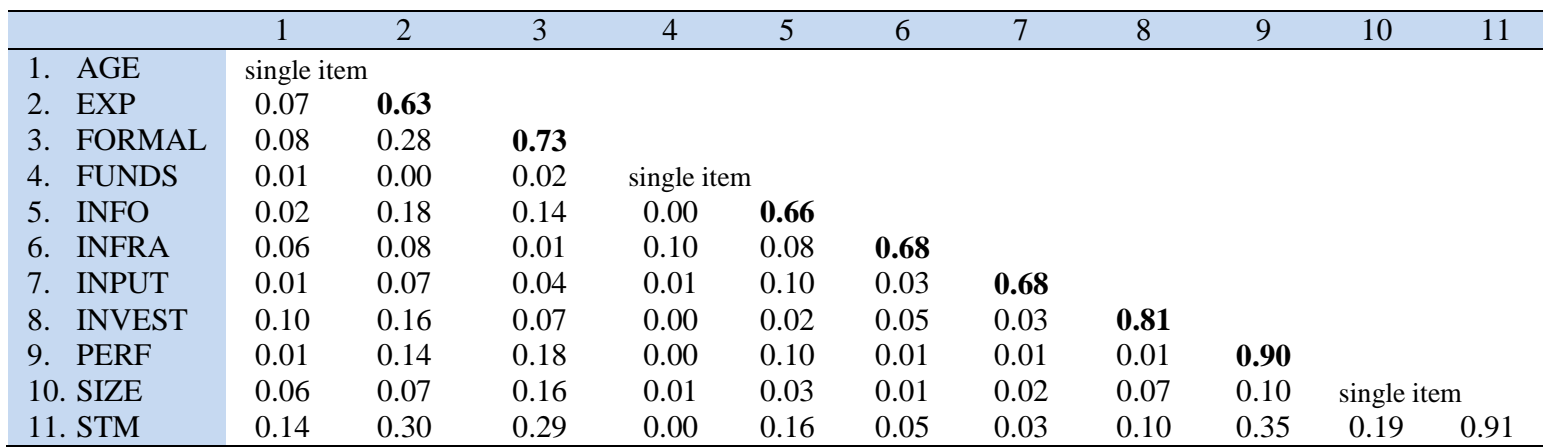

Note:

AVE values are positioned on the diagonal, and the correlations between the constructs are in the lower left triangle.

After variable measures have been confirmed as reliable and valid, we then assess the structural model for collinearity because the path coefficients may be biased if the estimation involves significant levels of collinearity among predictor variables. We run three sets of linear regression models on SPSS for the purpose of checking the variance inflation factor (VIF) values.

Appendix 2-2 shows that VIF values are below the threshold value of 5.0, thus indicating no multicollinearity problem. After assessing the quality of our measurements, we run the PLS algorithm to examine key results of the model.

\subsection{Results}

Table 2-6 shows resulting relationships between variables, path coefficients, Rsquared, t-statistics for the standardized path coefficients and p-values. The t-statistics were tested by running bootstrap with 5,000 re-samples. Table 2-6 also presents the results of the hypothesized structural model because one path characterizes each hypothesis. The results show that application of STM practices is influenced by a firm's distinguishing characteristics: firm age $\left(\mathrm{H}_{1 \mathrm{a}} ; 0.135^{* * *}\right)$, firm size $\left(\mathrm{H}_{1 \mathrm{~b}} ; 0.231^{* * *}\right)$ and formalization status of the firm $\left(\mathrm{H}_{1 \mathrm{c}} ; 0.227 * * *\right)$. Moreover, the application of STM practices is greater if there are high investment levels $\left(\mathrm{H}_{2 \mathrm{a}} ; 0.042 * * *\right)$, access to market 
information $\left(\mathrm{H}_{2 b} ; 0.061\right)$, increase in managers' level of expertise $\left(\mathrm{H}_{2 \mathrm{c}} ; 0.284 * * *\right)$ and better access to funds $\left(\mathrm{H}_{3 c} ; 0.089 *\right)$. In contrast, the effect of better availability of inputs and access to public infrastructure services do not significantly influence application of STM. Therefore, hypotheses $\mathrm{H}_{3 \mathrm{a}}$ and $\mathrm{H}_{3 \mathrm{~b}}$ are not supported. Altogether, 48.5 percent of the variance in application of STM practices is explained by the determinant (exogenous) variables in the model, with the highest contribution coming from managers' level of expertise, followed by firm size and the formalization status of the firm.

Hypothesis $\mathrm{H}_{4}$ was supported. The extent of strategic management practices significantly contributes to firm performance $(0.591 * * *)$; however, only 35 percent of the variance is explained.

Table 2-6: P-values and Hypothesis Testing

\begin{tabular}{|c|c|c|c|c|c|c|}
\hline Relationships & $\begin{array}{c}\text { Path } \\
\text { Coefficient }\end{array}$ & $\begin{array}{c}t- \\
\text { values }\end{array}$ & $p$-value & Sig. & Hypothesis & Decision \\
\hline $\mathrm{AGE} \rightarrow \mathrm{STM}$ & 0.135 & 3.189 & 0.002 & $* * *$ & H1 $H_{l a}$ & Supported \\
\hline $\mathrm{SIZE} \rightarrow \mathrm{STM}$ & 0.231 & 5.137 & 0.000 & $* * *$ & $H_{l b}$ & Supported \\
\hline FORMAL $\rightarrow$ STM & 0.227 & 3.377 & 0.000 & $* * *$ & $H_{l c}$ & Supported \\
\hline $\mathrm{INVEST} \rightarrow \mathrm{STM}$ & 0.042 & 4.398 & 0.000 & $* * *$ & H2 $H_{2 a}$ & Supported \\
\hline $\mathrm{INFO} \rightarrow \mathrm{STM}$ & 0.061 & 4.577 & 0.000 & $* * *$ & $H_{2 b}$ & Supported \\
\hline $\mathrm{EXP} \rightarrow \mathrm{STM}$ & 0.284 & 5.388 & 0.000 & $* * *$ & $H_{2 c}$ & Supported \\
\hline $\mathrm{INPUT} \rightarrow \mathrm{STM}$ & 0.015 & 0.990 & 0.323 & NS & H3 $H_{3 a}$ & Not supported \\
\hline INFRA $\rightarrow$ STM & 0.046 & 0.974 & 0.331 & NS & $H_{3 b}$ & Not supported \\
\hline FUNDS $\rightarrow$ STM & 0.089 & 1.713 & 0.088 & $*$ & $H_{3 c}$ & Supported \\
\hline $\mathrm{STM} \rightarrow$ PERF & 0.591 & $13.175^{1}$ & 0.000 & $* * *$ & H4 $H_{4}$ & Supported \\
\hline R- Squared values: & $\begin{array}{l}\text { STM } \\
\text { PERF }\end{array}$ & $\begin{array}{l}=0.485 \\
=0.350\end{array}$ & & & & \\
\hline
\end{tabular}

Predictive relevance $\mathrm{Q}^{2}$ is another criterion for the model assessment (Henseler et al., 2009) and values of $\mathrm{Q}^{2}$ larger than zero verify that our exogenous latent variables have predictive relevance for the endogenous latent variables STM and PERF. The results yield the values 0.337 for STM and 0.237 for PERF (see Appendix 2-3), which confirm the predictive relevance of the associated path model relationships. We then extend our findings of PLS-SEM outcomes by conducting the importance-performance matrix analysis (IPMA) as applied by Martilla and James (1977). 


\subsubsection{Importance-Performance Matrix Analysis (IPMA) for STM Practices}

IPMA is useful in extending PLS-SEM findings using latent variable scores. The matrix shows which attribute (i.e., exogenous variable) a manager should focus on in order to apply STM practices successfully. Thus, IPMA provides guidance for strategic development (Slack, 1994). The term importance refers to the impact of a latent variable on an endogenous (or target) variable, while performance represents responses from the data in a form of latent variable scores or index values. In generating the matrix, we use 'application of STM practices' as our target variable; thereafter total effects (importance) and index values (performance) are determined (Hair et al., 2013). The total effect of a path between two constructs is the sum of all the direct and indirect effects in a structural model derived from a PLS path model estimation. The index values, on the other hand, are derived by means of re-scaling all observation data to a range of 0 and 100 (see, Anderson and Fornell, 2000; Höck and Ringle, 2010) using the formula:

$$
X_{i}^{\text {rescaled }}=\frac{\left(x_{i}-\text { Minscale }[x]\right.}{(\text { Maxscale }[x]-\text { Minscale }[x])} \cdot 100
$$

$X_{i}$ represents $i^{\text {th }}$ data (latent variable score), Minscale $[x]$ represents the lowest, and Maxscale $[x]$ the highest value in the $x$ data (Höck \& Ringle, 2010). The mean values of all latent variable scores are rescaled with the higher values indicating better performance Table 2-7 shows the resulting total effect and latent variable index values extracted from a smartPLS report. If, for example, the index value of AGE increases by one unit, the index value of the target variable STM will increase by 0.135 points in a static manner of assessment (ceteris paribus). For quick interpretation of all variables, a graphic IPMA representation is created by using a Microsoft Excel spreadsheet application (see Figure 2-2). 


\section{Table 2-7: IPMA Results}

\begin{tabular}{llcc}
\hline Variable & & $\begin{array}{r}\text { Total Effects } \\
\text { (Importance) }\end{array}$ & $\begin{array}{c}\text { Index Values } \\
\text { (Performance) }\end{array}$ \\
\hline Firm age & AGE & 0.135 & 17.76 \\
Firm size & SIZE & 0.231 & 25.97 \\
Formalization status & FORMAL & 0.227 & 57.10 \\
Level of investment & INVEST & 0.042 & 29.71 \\
Access to market information & INFO & 0.061 & 77.77 \\
Managers' level of expertise & EXP & 0.284 & 60.38 \\
Availability of inputs & INPUT & 0.015 & 77.86 \\
Access to public infrastructure & INFRA & 0.046 & 55.66 \\
Access to funds & FUNDS & 0.089 & 60.35 \\
\hline
\end{tabular}

In terms of recognizing priority areas or issues requiring managerial action, attention should be paid to the variables that are positioned high on the $x$-and $y$-axes in Figure 2-2. Reading from the $x$-axis, managers' level of expertise ranks first on the importance scale, followed by firm size and formalization status, whereas availability of inputs ranks lowest. Reading from the $y$-axis, availability of inputs ranks first on the performance scale, followed by access to market information; in this case, firm age is the least important variable.

Overall, attention is given to the variables positioned in the top-right corner (see Figure 2-2), which indicates a relatively high share of importance and performance compared to other variables. In this case, managers' level of expertise and the formalization status of the firm are selected as areas of priority for the successful application of STM practices. 
Figure 2-2: IPMA Representation of Determinants of STM Practices

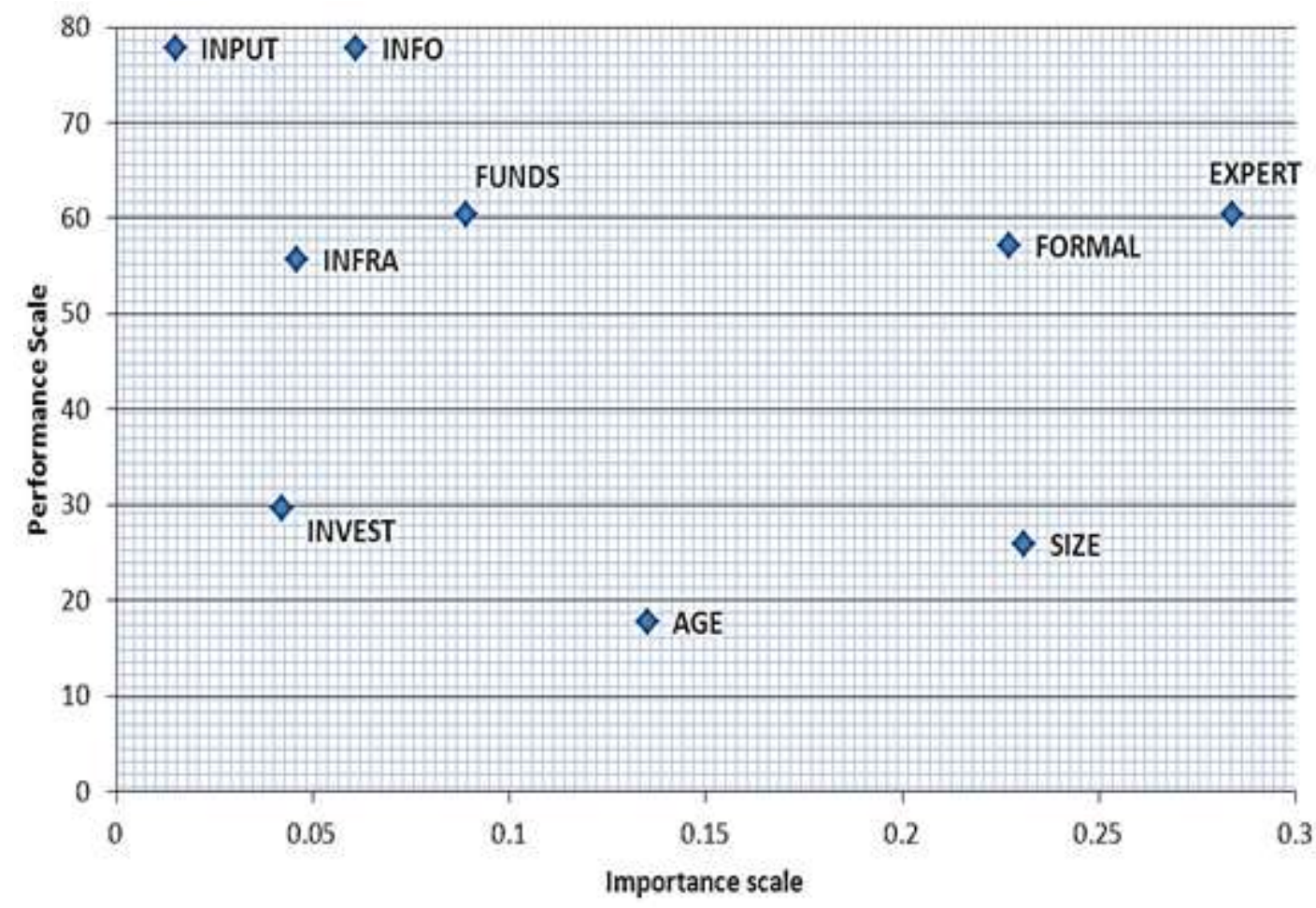

\subsection{Discussion and Conclusions}

The results of our analysis demonstrate a positive link $\left(\mathrm{H}_{4} ; 0.591 * * *\right)$ between strategic management practices and firm performance. This finding provides justification for the need of STM practices for firm survival in competitive and dynamic markets. Since we surveyed small enterprises, the results provide support for the argument that there is a need for strategic awareness not only in medium-sized and large enterprises but also in small ones (Gibb \& Scott, 1985). Furthermore, our empirical findings are in line with earlier studies that have indicated the positive effects of systematic strategic management in small enterprises (Andrews, Boyne and Walker, 2006; Bracker and Pearson, 1986; Georgellis et al., 2000).

Also, our analysis provides support for the notion that firm characteristics have a significant effect on STM practices. Looking at the path coefficient scores and IPMA presentation for each variable of firm characteristics separately, a firm's formalization status has a greater impact on the application of STM practices than its age and size (see Figure 2-2). The result is not in line with the study conducted by Bigsten et al. (2004), 
which found no high productivity strategy achieved by changing from informal to formal status. After all, developing countries often tolerate the operations of informal businesses due to their contribution to net employment growth. In addition, firms do not see any profit gains by formalizing their businesses. Informal firms usually engage in food processing business on a trial basis, using family members in a part-time position, with no clear structure or direction and no paperwork or financial records. This informal management style is contrary to Max Weber's (1968) assertion that creating formal authority structures in any business enables it to benefit from the so-called "technical superiority" of bureaucratic organization. Our study supports Weber, indicating that greater formalization will enhance firms' successful strategy implementation $\left(\mathrm{H}_{1 \mathrm{c}}\right.$; $0.227^{* * *}$ ) because they will have more opportunities to make investment efforts and participate in export activities than informal firms. Hence, formal firms will be in a good position to implement their strategies; however, this applies mostly to firms with greater age $\left(\mathrm{H}_{1 \mathrm{a}} ; 0.135 * * *\right)$ and larger size $\left(\mathrm{H}_{1 \mathrm{~b}} ; 0.231 * * *\right)$. The latter findings parallel early results from a contingency perspective in organization theory, which indicated that older and larger firms tend to become more formalized (Child, 1975). The trend towards increasing formalization and implementation of management systems has more recently been demonstrated for small growing enterprises, as well (Davila, 2005).

Further analysis provides support for the proposed relationship between available firm resources and the application of STM practices. Firm resources including investment level, access to information and management's expertise are positively associated with an increase in STM practices. These are helpful resources that support the implementation of strategies and hence gain and sustain competitiveness. The argument from the literature that firms with fewer resources aggressively engage in strategic practices (Ferrier, 2001) is not supported. The study looked at valuable resources for the food processing firms in this context and found that 'level of expertise' contributes most to STM implementation. Firms with relevant skills are in a good position to strategize well and position their products more easily in the market. The existing literature also indicates the same relationship, with no clear indication of which skills they are referring to (Ambrosini \& Bowman, 2009; Mugera, 2012). Among several skills investigated in this study, knowledge of food quality and safety standards, expertise in food processing and customer care were considered relevant. In contrast, firms with inadequate skills cannot implement their strategies successfully even if they have good 
strategic plans in place. From a more general point of view, the findings support the widely shared resource-based view that it is often intangible and human resources that provide a basis for long-term competitive advantages since these resources are often difficult to imitate or replace (Prahalad \& Hamel, 1990).

Our findings also show that the degree of a firm's ability to implement STM practices is influenced by better access to information $\left(\mathrm{H}_{2 b} ; 0.061^{* * *}\right)$. As long as information is accessed and understood, it can be used to unravel market uncertainties and hence formulate and implement strategies and control results. This supports Hitt et al.'s (2009) proposition that access to information is essential for strategic management steps such as environmental analysis, for which firms need to be informed about relevant elements of and changes in the firm's internal and external environments. Thus, firms with better access to information on where to get agricultural produce, produce prices, where to sell their products, customer needs, competitors' actions and other relevant topics have better opportunities to successfully engage in strategic actions than those with poor access. Those with poor access are uninformed about what they need to solve their problems and unable to understand market trends clearly; as a result, they lose focus in goal accomplishment.

Our study shows significant results for the effects of level of investment on STM practices. Firms that invested more on assets such as firm buildings and motor vehicles were able to carry out their regular production plans and transportation in a convenient environment with adequate space for food hygiene and safety. Such firms are able to implement their strategies and realize their potential. Similar arguments have been made in previous studies, which link the poor performance of manufacturing firms to poor investment capacity (Dinh et al., 2013). The resource-based view in strategic management also argues that there is a need for a sufficient resource basis for doing business although most of these resources do not provide competitive advantages (Barney, 1991). Hence, policies should aim to promote private investment in input to resolve one of any small firm's major challenges-how to attract interested venture capitalists to invest in a modern production plant, machinery and food processing equipment.

The results of this study also show that there are significant and insignificant factors in the external environment that affect the application of STM. Better input 
availability and access to public infrastructure services do not have a significant effect on the implementation of STM practices. The latter was surprising because we expected that access to public infrastructure would enhance the effective implementation of STM practices. It could be challenging in strategic implementation and monitoring aspects of STM if there is inadequate availability of electrical power, water, communications services, etc. The reason for our finding could be that the firms surveyed are not very exposed to external pressure compared with large firms that deal with complex transport logistics and exporting activities.

The conditions in firms' external environment shape the way they formulate their strategies. Previous studies indicated that pressure from the external environment can push firms to perform certain strategic actions (Heyder and Theuvsen, 2012; Smallbone and Wyer, 2006). Therefore, the only significant external environment factor was access to external sources of funds. Our results showed that the hypothesized positive effect of the access to funds and the implementation of STM practices was confirmed $\left(\mathrm{H}_{3 c}\right.$; $\left.0.089^{*}\right)$. STM practices were more prevalent in those firms which have more alternatives for financing current and future activities. Those with a lack of access to loans and complicated bank loan applications claimed that STM practices are expensive, irrelevant and time-consuming in light of the small earnings they make. These firms depend more on their owners' savings, which is often an inadequate and very limited source of finance for business operation and expansion; hence, better access to formal sources of funds, such as bank loans, is needed. This brings us to the essential point of having a strategic plan in place that will convince formal financial institutions to issue loans and attract potential investors. The plan will also motivate firms to work hard towards firm performance (since our $\mathrm{H}_{4}$ hypothesis is supported). Therefore, if we look at pressure from external environment factors, the greater focus is on access to external sources of funds.

The study provides manifold starting points for future research. For instance, it does not imply that there is a best resource or capability for all firms but rather that there are skills that are valid for the effective application of STM in this context. Scholars may further pursue studies of STM practices that focus on the entire portfolio of skills (e.g., marketing, finance, human resources and logistics) possessed by agribusiness managers. Such studies may further demonstrate the link between managerial skills, application of 
STM practices and firm performance. The analysis opens up another research path to explain the sphere of knowledge that determines effective strategic management practices. Overall, the conceptual model explains 48.5 percent of the variations in STM practices and 35 percent of the variation in firm performance. Obviously, there are other factors that have yet to be explored in order to explain the variability in our conceptual model.

We based our research on the fact that proper strategic plans and skills are needed to exploit food markets. Results support the view that internal organization resources are a critical link to strategic practices (Barney \& Hesterly, 2010) by discussing specific items in the study area context. The study contributes to the literature by providing a clarified categorization of important and relevant items for quick managerial actions. Thus, the findings provide various starting points for improving management practices and political and administrative actions. Since Tanzania has targeted the country's manufacturing sector to increase its contribution to GDP from 8 to 15 percent between 2009 and 2015 (MoFEA, 2010), knowledge and skills should be promoted, and research findings translated into productive actions. Overall, this research is an early inquiry into the strategic management process for firms of this nature in an emerging African economy. Much needs to be accomplished if it is to serve agribusinesses in the years ahead. Therefore, deeper qualitative and quantitative explorations are required in the future. 


\section{References}

Adler, P. S., \& Borys, B. (1996). Two types of bureaucracy: Enabling and coercive. Administrative Science Quarterly, 41(1), 61-89.

Admassie, A., \& Matambalya, F. A. S. T. (2002). Technical Efficiency of Small-and MediumScale Enterprises: Evidence from a Survey of Enterprises in Tanzania. Eastern Africa Social Science Research Review, 18(2), 1-29.

Ambrosini, V., \& Bowman, C. (2009). What are dynamic capabilities and are they a useful construct in strategic management? International Journal of Management Reviews, 11(1), $29-49$.

Anderson, E. W., \& Fornell, C. (2000). Foundations of the american customer satisfaction index. Total Quality Management, 11(7), 869-882.

Andrews, R., Boyne, G. A., Law, J., \& Walker, R. M. (2009). Strategy formulation, strategy content and performance: An empirical analysis. Public Management Review, 11(1), 1-22.

Andrews, R., Boyne, G. A., \& Walker, R. M. (2006). Strategy content and organizational performance: An empirical analysis. Public Administration Review, 66(January-February), $52-63$.

Bakar, A., Tufail, M. A., Yusof, M. N., \& Virgiyanti, W. (2011). Implementation of strategic management practices in the Malaysian construction industry. Pakistan Journal of Commerce and Social Sciences, 5(1), 140-154.

Bakker, H. (2011). Food security in Africa and Asia: Strategies for small-scale agricultural development (p. 247). Cambridge, MA, USA: CAB International.

Barney, J. B. (1991). Firm resources and sustained competitive advantage. Journal of Management, 17(1), 99-120.

Barney, J. B., \& Hesterly, W. S. (2010). Strategic management and competitive advantage concepts. Upper Saddle River, NJ: Pearson Prentice Hall.

Beaver, G. (2002). Strategy and Management in the Smaller Enterprise. Strategic Change, 11(4), $175-181$.

Beck, T., Demirguc-Kunt, A., \& Levine, R. (2005). SMEs, growth, and poverty: Cross-country evidence. Journal of Economic Growth, 10, 199-229.

Bigsten, A., \& Gebreeyesus, M. (2007). The small, the young , and the productive: Determinants of manufacturing firm growth in Ethiopia. Economic Development and Cultural Change, 55(4), 813-840.

Bigsten, A., Kimuyu, P., \& Lundvall, K. (2004). What to Do with the Informal Sector? Development Policy Review, 22(6), 701-715.

Bloom, N., \& Van Reenen, J. (2007). Measuring and Explaining Management Practices across Firms and Countries. The Quarterly Journal of Economics, 122(4), 1351-1408. 
Boehlje, M., Roucan-Kane, M., \& Bröring, S. (2011). Future agribusiness challenges: Strategic uncertainty, innovation and structural change. International Food and Agribusiness Management Review, 14(5), 53-82.

Boyne, G. A., \& Walker, R. M. (2004). Strategy Content and Public Service Organizations. Journal of Public Administration Research and Theory, 14(2), 231-252.

Bracker, J. S., \& Pearson, J. N. (1986). Planning and Financial Performance of Small, Mature Firms. Strategic Management Journal, 7(6), 503-522.

Burke, W. W. (2011). Organization Change Theory and Practice (3rd ed., p. 362). Los Angeles: Sage Publications Inc.

Chen, H. (2005). A Competence-based Strategic Management Model Factoring in Key Success Factors and Benchmarking. Benchmarking: An International Journal, 12(4), 364-382.

Child, J. (1975). Managerial and Organizational Factors Associated with Company Performance - Part II: A Contingency Analysis. Journal of Management Studies, 12(1-2), 12-27.

Collis, D. J. (1991). A Resource Based Analysis of Global Competition: The Case of the Bearings Industry. Strategic Management Journal, 12(S1), 49-68.

Cooper, C. L., Argyris, C., Starbuck, W. H., \& McGee, J. (2005). The Blackwell Encyclopedia of Management: Vol. 12 (2nd ed.). Malden, MA: Wiley-Blackwell.

Coviello, N. E., Brodie, R. J., \& Munro, H. J. (2000). An Investigation of Marketing by Firm Size. Journal of Business Venturing, 15(5), 523-545.

Davila, T. (2005). An exploratory study on the emergence of management control systems: Formalizing human resources in small growing firms. Accounting, Organizations and Society, 30(3), 223-248. Retrieved from http://linkinghub.elsevier.com/retrieve/pii/S036136820400042X

Dinh, H. T., Monga, C., Morisset, J., Kweka, J., Yagci, F., \& Yoshino, Y. (2013). Light manufacturing in Tanzania: A reform agenda for job creation and prosperity (p. 116). Washington DC 20001: The World Bank.

Dobbs, M., \& Hamilton, R. T. (2007). Small Business Growth: Recent Evidence and New Directions. International Journal of Entrepreneurial Behaviour \& Research, 13(5), 296-322.

Fafchamps, M., \& Quinn, S. (2012). Results of Sample Survey in Firms. In H. T. Dinh \& G. R. G. Clarke (Eds.), Performance of Manufacturing Firms in Africa: An Empirical Analysis (pp. 139-211). Washington, D.C: The World Bank.

Fajnzylber, P., Maloney, W., \& Rojas, G. M. (2006). Microenterprise Dynamics in Developing Countries: How Similar are They to Those in the Industrialized World? Evidence from Mexico. The World Bank Economic Review, 20(3), 389-419.

Fard, D. H., Moshabbaki, A., Abbasi, T., \& Hassanpoor, A. (2011). Strategic Management in the Public Sector: Reflections on Its Applicability to Iranian Public Organizations. Public Organization Review, 11, 385-406.

Fayol, H. (1921). L'Incapacité industrielle de l'État: Les P.T.T. Paris: Dunod. 
Ferrier, W. J. (2001). Navigating the Competitive Landscape: The Drivers and Consequences of Competitive Aggressiveness. Academy of Management Journal, 44(4), 858-877.

Fornell, C., \& Larcker, D. F. (1981). Evaluating structural equation models with unobservable variables and measurement error. American Marketing Association, 18(1), 39-50.

Freeman, R. E. (2010). Strategic Management: A Stakeholder Approach. Cambridge: CUP.

Gary, M. S., Wood, R. E., \& Pillinger, T. (2012). Enhancing Mental Models, Analogical Transfer, and Performance in Strategic Decision Making. Strategic Management Journal, 33(11), 1229-1246.

Georgellis, Y., Joyce, P., \& Woods, A. (2000). Entrepreneurial action, innovation and business performance: The small independent business. Journal of Small Business and Enterprise Development, 7(1), 7-17.

Gibb, A., \& Scott, M. (1985). Strategic Awareness, Personal Commitment and the Process of Planning in the Small Business. Journal of Management Studies, 22(6), 597-634.

Grant, R. M. (2013). Contemporary Strategy Analysis: Text and Cases (8th ed., p. 842). West Sussex, UK: John Wiley \& Sons, Inc.

Haenlein, M., \& Kaplan, A. M. (2004). A Beginner's Guide to Partial Least Squares Analysis. Understanding Statistics, 3(4), 283-297.

Hair, J. F., Hult, G. T. M., Ringle, C. M., \& Sarstedt, M. (2014). A Primer on Partial Least Squares Structural Equation Modeling (PLS-SEM). Thousand Oaks, CA: Sage Publications, Inc.

Hair, J. F., Ringle, C. M., \& Sarstedt, M. (2013). Partial Least Squares Structural Equation Modeling: Rigorous Applications, Better Results and Higher Acceptance. Long Range Planning, 46(1-2), 1-12.

Henseler, J., Ringle, C. M., \& Sinkovics, R. R. (2009). The Use of Partial Least Squares Path Modeling in International Marketing. Advances in International Marketing, 20(2009), 277319.

Heyder, M., \& Theuvsen, L. (2008). Strategic management in the German brewing industry: Are there still differences between East and West. Journal for East European Management Studies, 13(1), 10-39.

Heyder, M., \& Theuvsen, L. (2012). Determinants and effects of corporate social responsibility in German agribusiness: A PLS model. Agribusiness, 28(4), 400-420.

Hitt, M. A., Ireland, D. R., \& Hoskisson, R. E. (2009). Strategic management: Competitiveness and globalization: Concepts and cases (8th ed.). Mason, OH: South-Western Cengage Learning.

Höck, M., \& Ringle, C. M. (2010). Local strategic networks in the software industry: An empirical analysis of the value continuum. International Journal of Knowledge Management Studies, 4(2), 132-151.

Hofer, C. W., \& Schendel, D. (1978). Strategy Formulation: Analytical Concepts. St. Paul: West Group. 
Jin, S., \& Deininger, K. (2008). Key Constraints for Rural Non-Farm Activity in Tanzania: Combining Investment Climate and Household Surveys. Journal of African Economies, 18(2), 319-361.

Kinda, T., \& Loening, J. L. (2010). Small Enterprise Growth and the Rural Investment Climate: Evidence from Tanzania. African Development Review, 22(1), 173-207.

Kweka, J. (2006). Trade Policy and Transport Costs in Tanzania. CREDIT Research Paper, University of Nottingham, No 06/10,33.

Kweka, J., \& Fox, L. (2011). The household enterprise sector in Tanzania: why it matters and who cares. Policy Research Working Paper; No WPS 5882. Washington, D.C.

Martilla, J. A., \& James, J. C. (1977). Importance-Performance Analyses. Journal of Marketing, 41(1), 77-79.

McKenzie, D., \& Sakho, Y. S. (2010). Does it pay firms to register for taxes? The impact of formality on firm profitability. Journal of Development Economics, 91(1), 15-24.

Miles, M. P., Covin, J. G., \& Heeley, M. B. (2000). The Relationship between Environmental Dynamism and Small Firm Structure, Strategy, and Performance. Journal of Marketing Theory and Practice, 8(2), 63-78.

Miller, D., \& Friesen, P. H. (1983). Strategy-Making and Environment: The Third Link. Strategic Management Journal, 4(3), 221-235.

Ministry of Finance and Economic Affairs. (2010). National Strategy for Growth and Reduction of Poverty II: NSGRP II. Retrieved July 20, 2014, from http://www.acdicida.gc.ca/INET/IMAGES.NSF/vLUImages/Tanzania/\$file/NATIONAL-STRATEGYFOR-GROWTH-AND-REDUCTION-OF-POVERTY-TANZANIA.PDF

Mugera, A. W. (2012). Sustained Competitive Advantage in Agribusiness: Applying the Resource-based Theory to Human Resources. International Food and Agribusiness Management Review, 15(4), 27-48.

Nelson, E. G., \& DeBruijn, E. J. (2005). The Voluntary Formalization of Enterprises in a Developing Economy - The Case of Tanzania. Journal of International Development, 17(4), 575-593.

Ng, D., \& Siebert, J. W. (2009). Toward Better Defining the Field of Agribusiness Management. International Food and Agribusiness Management Review, 12(4), 123-142.

Niederhut-Bollmann, C., \& Theuvsen, L. (2008). Strategic management in Turbulent Markets: The Case of the German and Croatian Brewing Industries. Journal of East European Management Studies, 16(1), 63-88.

Nutt, P. C. (2004). Expanding the Search for Alternatives during Strategic Decision-making. Academy of Management Executive, 18(4), 13-28.

Penrose, E. T. (1959). The Theory of the Growth of the Firm. Oxford: Basil Blackwell.

Porter, M. E. (1980). Competitive Strategy: Techniques for Analyzing Industries and Competitors. New York and London: Free Press. 
Prahalad, C. K., \& Hamel, G. (1990). The Core Competence of the Corporation. Harvard Business Review, 68(3), 79-91.

Rama, R. (Ed.). (2005). Multinational Agribusinesses. New York.

Robbins, S. P., \& Judge, T. A. (2012). Organisation Behavior (15th ed., p. 720). Prentice Hall PTR.

Schwenk, C. R., \& Shrader, C. B. (1993). Effects of Formal Strategic Planning on Financial Performance in Small Firms: A Meta-Analysis. Entrepreneurship Theory and Practice, 17(3), 53-64.

Slack, N. (1994). The Importance-Performance Matrix as a Determinant of Improvement Priority. International Journal of Operations \& Production Management, 14(5), 59-75.

Smallbone, D., \& Wyer, P. (2006). Growth and Development in the Small Business. In S. Carter $\&$ D. JonesEvans (Eds.), Enterprise and Small Business: Principles, Practice and Policy. Pearson Education.

Stacey, R. D. (2011). Strategic management and Organisational Dynamics: The Challenge of Complexity (6th ed.). Upper Saddle River, NJ: Pearson Prentice Hall/Financial Times Press.

Sull, D. (2009). How to Thrive in Turbulent Markets. Harvard Business Review, 78-88.

Theuvsen, L., Heyder, M., \& Niederhut-Bollmann, C. (2010). Does Strategic Group Membership Affect Firm Performance? An Analysis of the German Brewing Industry. German Journal of Agricultural Economics, 59(1), 61-76.

Theuvsen, L., Janze, C., \& Heyder, M. (2010). Agribusiness in Germany 2010. On the Way to New Markets. Hanover.

Trienekens, J. H. (2011). Agricultural Value Chains in Developing Countries A Framework for Analysis. International Food and Agribusiness Management Review, 14(2), 51-82.

VanDuren, E., Sparling, D., Turvey, C., \& Lake, L. (2003). An assessment of the strategies and strengths of medium-sized food processors. Agribusiness, 19(1), 115-132.

Weber, M. (1968). Economy and Society: An Outline of Interpretive Sociology. New York: Bedminster Press.

Weinrauch, J. D., Mann, O. K., Patricia, A., \& Pharr, J. (1991). Dealing with Limited Financial Resources: A Marketing Challenge for Small Business. Journal of Small Business Management, 29(4), 44-53.

Welsh, J. A., \& White, J. F. (1981). A Small Business Is Not a Little Big Business. Harvard Business Review, 59(4), 18-27.

Wheelen, T. L., \& Hunger, J. D. (2006). Strategic Management and Business Policy. Upper Saddle River, NJ: Pearson Education, Inc.

Woods, A., \& Joyce, P. (2003). Owner-managers and the practice of strategic management. International Small Business Journal, 21(2), 181-195. 
Chapter Two: The Impact of External and Internal Factors on Strategic Management Practices of Agribusiness Firms in Tanzania

Zhang, S., \& Li, X. (2008). Managerial ties, firm resources, and performance of cluster firms. Asia Pacific Journal of Management, 25(4), 615-633. 


\section{Appendix 2-1: Descriptive Statistics of Variable Items}

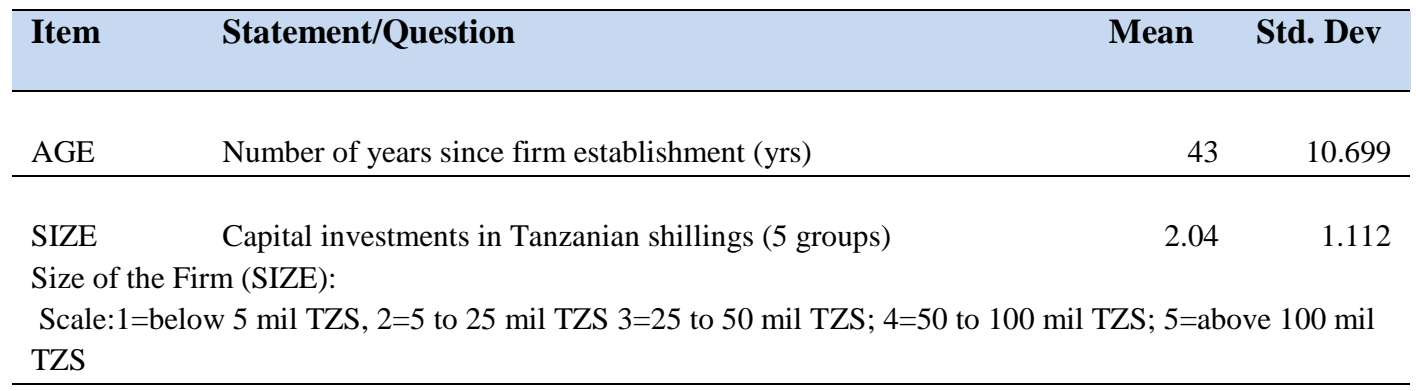

Formal status (FORMAL): Formalization status of the firm (scale from $1=$ strongly disagree to $5=$ strongly agree)

\begin{tabular}{llll} 
FORM_1 & You have a picture of an organization structure. & 3.11 & 1.060 \\
FORM_2 & You have indicated clearly the division of work for employees. & 3.39 & 1.035 \\
FORM_3 & You have written a clear business plan. & 3.17 & 1.035 \\
FORM_4 & You are able to abide by all legal business regulations. & 3.47 & 1.066 \\
\hline
\end{tabular}

Investment Level (INVEST): 1=Very low, 2=Low (25\%), 3=Average (50\%), 4=High (75\%) 5=Very

high (up to $100 \%$ )

\begin{tabular}{llrr} 
INVEST_1 & How much have you invested in firm buildings? & 2.38 & 1.385 \\
INVEST_2 & How much have you invested in firm's motor vehicles? & 2.04 & 1.165 \\
INVEST_3 & How much have you invested in employee training? & 2.50 & 1.211 \\
INVEST_4 & How much have you invested in production technology? & 3.41 & 1.028 \\
INVEST_5 & How much have you invested in office tools (raw materials, salary, & & \\
& water and electricity tools)? & 2.82 & 1.332 \\
INVEST_6 & How much have you invested in marketing activities? & 2.95 & 1.211 \\
\hline
\end{tabular}

Firm's access to information (INFO)

Scale: $1=$ Completely inaccessible $2=$ Inaccessible, $3=$ Average access, $4=$ Accessible and 5=Highly accessible

\begin{tabular}{llrl} 
INFO_1 & Information on where to get raw materials & 4.34 & 0.941 \\
INFO_2 & Information on changes in product prices & 4.04 & 1.049 \\
INFO_3 & Information on where to sell & 3.97 & 0.993 \\
INFO_4 & Information concerning customers' whereabouts & 3.89 & 1.014 \\
INFO_5 & Information about when to sell & 3.92 & 1.013 \\
INFO_6 & Information on competitors & 3.70 & 1.128 \\
INFO_7 & Information on tax rates & 3.38 & 1.286 \\
INFO_8 & Information on trade associations & 3.61 & 1.177 \\
\hline
\end{tabular}

Level of manager's expertise (EXP) scale from $1=$ strongly disagree to $5=$ strongly agree

\begin{tabular}{llrl} 
EXP_1 & Level of expertise in bookkeeping and accounting & 3.03 & 1.094 \\
EXP_2 & Level of expertise in managing employees & 3.45 & 1.053 \\
EXP_3 & Level of expertise in marketing techniques & 3.26 & 1.056 \\
EXP_4 & Level of expertise in financial management & 3.21 & 1.107 \\
EXP_5 & Level of expertise in stocktaking \& recordkeeping & 3.36 & 1.081 \\
EXP_6 & Level of expertise in food quality \& safety standards & 3.56 & 1.056 \\
EXP_7 & Level of expertise in customer care & 3.72 & 1.006 \\
EXP_8 & Level of expertise in product presentation & 3.37 & 1.074 \\
EXP_9 & Level of expertise in food processing & 3.73 & 1.070 \\
\hline
\end{tabular}

Input availability (INPUT) Scale: 1=Not available 3=Available 5=Easily available

\begin{tabular}{llrr} 
INPUT_1 & Availability of Agricultural Inputs & 4.34 & 0.870 \\
INPUT_2 & Availability of Non-Agricultural Inputs & 3.85 & 1.014 \\
\hline
\end{tabular}




\begin{tabular}{llrl}
\hline Item & Statement/Question & Mean & Std. Dev \\
& & \\
& & \\
Access to public infrastructure level (INFRA): & scale from 1=strongly disagree to 5=strongly agree & \\
INFRA_1 & The firm is located along the regional highway. & 3.41 & 1.273 \\
INFRA_2 & The firm is in the city center. & 3.42 & 1.265 \\
INFRA_3 & There is access to telephone services. & 4.42 & 0.695 \\
INFRA_4 & There is access to electricity. & 4.40 & 0.730 \\
INFRA_5 & There is access to water. & 4.37 & 0.749 \\
INFRA_6 & There is continuous phone service. & 4.36 & 0.799 \\
INFRA_7 & There is a continuous and uninterrupted electricity supply. & 3.11 & 1.246 \\
INFRA_8 & There is a continuous and uninterrupted water supply. & 3.21 & 1.254 \\
\hline
\end{tabular}

Access to Funds (FUNDS): Scale: 1=Very poor 2=Poor 3=Fair 4=Good 5=Very good

$\begin{array}{llll}\text { FUNDS } & \text { Access to funds aggregate mean score } & 3.4 & 0.79\end{array}$

Strategic management practices (STM) practices (scale from 1=Strongly disagree to 5=Strongly agree) You have developed a list of strengths and weaknesses (of the

STM 1 firm)

STM_2

You are informed about all opportunities that are good for firm

STM_3 You understand your customers and what products they need.

STM_4 You have visualized what your firm might be like five to ten years from now.

STM 5 You have developed a list of the firm's objectives. $\quad 3.37 \quad 1.252$

STM_6 $\quad$ The objectives are regularly updated. $\quad 3.14 \quad 1.261$

$\begin{array}{llll}\text { STM_7 } & \text { The objectives are known to every employee. } & 3.24 & 1.318\end{array}$

STM_8 You have a fully developed operational procedures manual. $\quad$\begin{tabular}{lll}
1.354 \\
\hline
\end{tabular}

$\begin{array}{llrr}\text { STM_9 } & \text { Work procedures are fully communicated. } & 3.24 & 1.320\end{array}$

STM_10 The procedures are fully understood by every employee. $\quad 3.42 \quad 1.353$

$\begin{array}{llll}\text { STM_11 The firm can afford to finance actual implementation of strategies. } & 3.16 & 1.247\end{array}$

STM_12 Employees are fully committed to the implementation of strategies. $\quad 3.47 \quad 1.293$

STM_13 There is an adequate number of staff to implement firm strategies. $\quad 3.19 \quad 1.303$

$\begin{array}{llll}\text { STM_14 There are enough competencies to implement the strategies. } & 3.10 & 1.254\end{array}$

$\begin{array}{llrl}\text { STM_15 You regularly compare your activities to your plans. } & 3.41 & 1.273\end{array}$

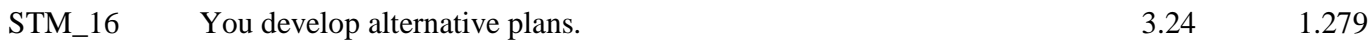

$\begin{array}{llrl}\text { STM_17 } & \text { You regularly compare your strategies with those of your } & 3.33 & 1.331\end{array}$ competitors.

Performance (PERF) $1=$ Decrease $2=$ Slight decrease $3=$ The same as in the preceding year $4=$ Slight increase $5=$ Increase

\begin{tabular}{llrl} 
Rev_1a & Sales revenue this year (2013) & 3.73 & 1.082 \\
Rev_1b & Sales revenue last year (2012) & 3.60 & 0.971 \\
Rev_1c & Sales revenue in 2011 & 3.50 & 0.991 \\
\hline
\end{tabular}


Chapter Two: The Impact of External and Internal Factors on Strategic Management Practices of Agribusiness Firms in Tanzania

\section{Appendix 2-2: Collinearity Assessment}

\begin{tabular}{llll}
\hline Model 1: & Model 2: & Model 3: & \\
INFO (1.23) & INPUT (1.028) & FORMAL (1.601) & AGE (1.200) \\
EXP (1.44) & INFRA (1.028) & SIZE (1.263) & Rs (1.694) \\
INVEST (1.12) & & EXT (1.344) & FUNDS (1.302) \\
(as predictors of Rs) & (as predictors of EXT) & (as predictors of STM) \\
\hline
\end{tabular}

Note: VIF values in Parentheses. VIF is a metric for multicollinearity

Appendix 2-3: Effect Sizes ( $f^{2}$ and $q^{2}$ values)

\begin{tabular}{|c|c|c|c|c|c|c|c|}
\hline $\begin{array}{c}\text { Path } \\
\text { Relationships }\end{array}$ & $\begin{array}{l}\text { Path } \\
\text { Coeff. }\end{array}$ & $\begin{array}{c}\text { t- } \\
\text { values }\end{array}$ & $\begin{array}{c}\text { p- } \\
\text { value }\end{array}$ & Sig. & & $\begin{array}{l}f^{2} \\
\text { ct Size }\end{array}$ & $\begin{array}{c}q^{2} \\
\text { Effect Size }\end{array}$ \\
\hline SIZE $\rightarrow$ STM & 0.231 & 5.126 & 0.000 & $* * *$ & 0.07 & Small & 0.05 \\
\hline $\mathrm{AGE} \quad \rightarrow \mathrm{STM}$ & 0.135 & 3.211 & 0.002 & $* * *$ & 0.03 & Small & 0.02 \\
\hline $\mathrm{FORMAL} \rightarrow \mathrm{STM}$ & 0.227 & 3.464 & 0.000 & $* * *$ & 0.06 & Small & 0.03 \\
\hline $\mathrm{RS} \quad \rightarrow \mathrm{STM}$ & 0.334 & 5.366 & 0.000 & $* * *$ & 0.11 & Small & 0.06 \\
\hline $\mathrm{EXT} \rightarrow \mathrm{STM}$ & 0.051 & 0.964 & 0.168 & NS & 0.004 & Small & 0.004 \\
\hline FUNDS $\rightarrow$ STM & 0.089 & 1.716 & 0.086 & $*$ & 0.01 & Small & 0.01 \\
\hline $\mathrm{STM} \rightarrow \mathrm{PERF}$ & 0.591 & 13.786 & 0.000 & $* * *$ & 0.31 & Medium & 0.08 \\
\hline \multicolumn{8}{|c|}{ Endogenous latent variables } \\
\hline STM & \multirow{2}{*}{\multicolumn{2}{|c|}{$\mathbf{Q}^{2}$ values }} & 0.337 & & & & \\
\hline PERF & & & 0.237 & & & & \\
\hline
\end{tabular}

Note:

$\mathrm{Q}^{2}>0$ means there is predictive relevance. $\mathrm{Q}^{2}<0$ indicates there's no predictive relevance. "q-squared" $\left(q^{2}\right)$ values represent the effect sizes. Values of $0.02,0.15$ and 0.35 indicate that the independent variable has a small (S), medium (M) and large (L) predictive size for our dependent variable. 


\title{
Chapter Three
}

\section{Agribusiness Firm Resources and Performance: The Mediation Role of Strategic Management Practices}

Theresia Dominic and Ludwig Theuvsen

\begin{abstract}
This study investigates the relationship between firm resources, strategic management practices and firm performance of small agribusiness firms. Looking at level of managerial expertise and access to market information as primary resources, this research presents various arguments about their contribution to firm performance. The objective is to demonstrate the role of strategic management practices in facilitating the effective use of these resources to achieve agribusiness firm performance. Results from a structural equation model using a sample of 229 agribusiness firms from Tanzania indicate that the investigated resources alone do not directly contribute to firm performance unless there is application of strategic management as a potential mediator. Further investigation based on multigroup analysis shows contingency effects in the resources-performance relationship but significant influence of application of strategic management practices on performance across all groups of firms. The results imply that managers ought to identify a fit between their resources and strategic actions in order to enhance firm performance. The study provides manifold managerial implications for small firms that seek to improve firm performance.
\end{abstract}

This paper has been published in this similar version as a discussion paper within the Global Food Discussion Paper Series. 


\subsection{Introduction}

The relationships between firm resources, corporate and competitive strategies and firm performance are at the focus of strategic management (for instance, Grant, 2013) as well as agribusiness management research (e.g., Theuvsen et al., 2010). Many researchers have also looked at firm resources, strategic management (STM) practices and performance in small agribusiness firms. First, it is because of small firms' challenges in utilizing resources to improve firm performance (Bloom \& Van Reenen, 2007; Edelman et al., 2005), for instance due to a lack of sufficient management capabilities (Beaver, 2007; Hatten, 2012). Furthermore, small firms' potential for growth strongly depends on improvement of their strategic behavior (Bakker, 2011).

Performance of small agribusiness firms has also been the focus of developing economies such as Tanzania (Dinh et al., 2013; HODECT, 2010). Development programs in developing countries often make efforts to commercialize the food sector; hence new pathways to enhance firm performance are needed, especially with regard to small and medium-sized firms (Byerlee et al., 2013). But, current practices are often insufficient, especially in African agribusiness firms, in embracing essential management tools (Dinh et al., 2013; IFAMR, 2014) such as strategic management practices as indicated in Beaver (2007)'s study. The truth is that we know very little about STM practices of small agribusiness firms. Due to this lack of knowledge, practices such as setting performance goals and analyzing a firm's environment are wrongly considered to be irrelevant for these firms. Instead, the STM process is thought to be exclusively applicable to large corporate firms. In this regard, lack of strategic practices causes difficulties for small firm managers to market their products (Admassie \& Matambalya, 2002; Kinda \& Loening, 2010). In Tanzania, for instance, the essence of improved firm competitiveness is not seen even though managerial training for managers of small firms is conducted to improve strategic firm operations. This is evidenced by weak entrepreneurial and workers' skills as well as increasingly unprofitable transactions among agribusinesses in Tanzania (Dinh et al., 2013; Fafchamps \& Quinn, 2012). The insufficient focus on STM practices is also evidenced in other African countries by, for instance, production of low quality of food products, selling of products without processing, poor application of value adding activities, lack of good quality packaging materials compared to imported share, and inadequate capacity to secure loans from 
Chapter Three: Agribusiness Firm Resources and Performance: The Mediation Role of Strategic Management Practices

financial institutions as a result of poor business planning and record keeping (IFAMR, 2014)

In this context the role and importance of resources have been researched extensively (Barney, 1991; Mugera, 2012; Penrose, 1959). Managerial expertise and capabilities are key resources to organizations as long as they are strategically positioned to enhance performance (Ambrosini \& Bowman, 2009; Mugera, 2012; Pansiri \& Temtime, 2008). They are also considered as primary resources in the development of food value chain structures (Mikkola, 2008). Nevertheless, some studies which analyzed the effect of human capital on performance indicate that the link can be both direct and indirect (Hitt et al., 2001), meaning that a certain level of expertise might not guarantee overall firm performance especially if there is insufficient ability to apply the skills or if the skills are not valuable for firm-specific operations (Barney, 2001). Several cases of agribusiness firms in Africa have shown poor managerial expertise in business operations (IFAMR, 2014) and those that succeeded have indicated different styles of management and strategy. This supports earlier findings from Chan et al. (2006) that small firms are heterogeneous in their strategy as they develop. Hence, the relationship between managerial expertise and firm performance as well as differences in the influence of managerial expertise on performance needs to be examined in more detail.

Access to market information is another resource that is crucial to agribusiness firms because it enhances better positioning in competitive markets (Byerlee et al., 2013; Lwoga et al., 2011). Small firms operating in a competitive environment may be unable to process information to their own advantage due to a lack of preliminary strategic goals and an unwillingness to plan properly (Beaver, 2007). When food processors are unaware of market information, they remain at a mercy of other actors in a value chain who might dictate unfair business terms (HODECT, 2010). In this case, information access such as knowledge about the availability of raw materials, prices, competitors' actions, trade associations, suppliers and amount of demand may have an impact on strategy planning and hence firm performance (Byerlee et al., 2013). Moreover, the style of using information could differ among firms due to the premise that firms' journeys of attaining performance are heterogeneous (Chan et al., 2006). Therefore, the relationship between access to market information and firm performance as well as differences in the influence of the information on performance also need to be examined more thoroughly. 
Even though level of managerial expertise and access to market information are key resources to firms, there are variables that intervene in determining firm performance; therefore, as indicated earlier, their direct contribution to performance is not always the case. For example Penrose (2009) in her latest reviewed work argues that resources themselves are not adequate for successful operations, rather it is the way these resources are used. Therefore, we posit that the application of STM practices is among such intervening variables. One of the methods for examining the role of STM practices as an intervening variable is through mediation analysis. The analysis specifies the existence of a significant intervening mechanism between an independent and dependent variable, which might not exist in the absence of a mediator (Baron \& Kenny, 1986).

Against this background, our general research objective is to demonstrate the pivotal role of STM practices in facilitating effective use of potential resources to increase firms' performance. More specifically, we want to analyze whether both managerial expertise and access to market information link directly to firm performance or whether this relationship is mediated by application of STM practices. Further analysis will uncover group differences in deployment of firm resources such as managerial skills and access to market information in achieving firm performance through application of strategic management practices. In doing so we take a deeper look into segments of firms that are homogenous in the contribution of STM practices as a mediator. The results could help to motivate small firm managers to utilize essential managerial tools for firm operations.

The remainder of this paper is organized as follows: In Section 3.2 we present the literature on the concept of strategic management in an agribusiness context, our hypotheses and conceptual framework. In Section 3.3, we describe the research design and data used for our model estimation. Section 3.4 presents results of a survey of 229 Tanzanian agribusiness firms using partial least squares methodology to evaluate our structural equation model. Further analyses are conducted to detect the mediating effect of STM practices. A multigroup analysis of our sample reveals differences between different segments of small agribusiness firms with regard to the relationships between firm resources, STM practices and firm performance. Section 3.5 provides a discussion on managerial implications and some concluding remarks. 


\subsection{Literature Review}

\subsubsection{Role of Strategic Management Practices (STM)}

Based on earlier writings in the 1950s and 1960s, the field of strategic management (STM) emerged mainly during the 1970s and early 1980s from the social and administrative sciences because of a growing interest to understand the principles driving organizations to sustainable performance (for an excellent review, see Hoskisson et al., 1999). The field is distinguished from other managerial activities which are concerned with day-to-day, short term and tactical activities. The STM process of a firm starts by the definition of clear vision, mission and objectives, defined by using information from environmental analysis and a thorough analysis of firm resources. The process is followed by strategy planning, strategy implementation, strategy evaluation and control (Grant, 2013; Hitt et al., 2009). STM practices bring a long-term and big picture perspective and give a clear purpose of an organization and the direction it intends to go (Andrews, Boyne, \& Walker, 2006; Stacey, 2011). The targeted audiences are managers, managers-to-be and policy-makers whom should be reached for influence, while shaping both training institutions and markets (Mahoney \& McGahan, 2007). However, the users, mostly of small firms often view STM as being unnecessarily theoretical and refrain from engaging in STM practices because it is either a complex or a demanding process considering the firms' limited capital and other resources (Beaver, 2007).

With the development of the resource-based view in strategic management (RBV) (Barney, 1991; Wernerfelt, 1984), the STM field has increased its emphasis on identifying valuable firm resources in achieving sustainable competitive advantage and above-average financial returns. Since firms have a bundle of specialized resources that wait to be utilized effectively, the view posits that with well managed resources, firms will have the potential to create economic value. The potential is realized when the resources are aligned with the overall firm strategy (Barney \& Hesterly, 2010; Mugera, 2012; Wernerfelt, 1984). Its framework is adopted for analyzing performance because RBV emphasizes strategic actions for managers to plan and deploy these resources to maximize returns. Also, Edelman et al. (2005) imply that the theory incorporates application of strategic actions as a mediating variable between resources and firm performance. The aim of the RBV is to enable firms to leverage those rare, valuable, 
Chapter Three: Agribusiness Firm Resources and Performance: The Mediation Role of Strategic Management Practices

non-imitable, non-substitutable and durable resources that only contribute to firm performance (Barney, 2001).

In the process of leveraging the resources, depending too much on tangible resources such as machinery and equipment is not as beneficial to firm's survival. Ability and knowledge to use it are more decisive. Therefore, we include managerial expertise and access to information as critical resources in our conceptual model (see Figure 3-1) because they guarantee a firm's survival. For example, a firm that has lost its tangible resources but kept the skills and knowledge of its workforce could continue its operations relatively quickly (Becker et al., 2001). Thus, the strategic management field calls for competency based competition in order for small firms to respond to existing challenges and opportunities. The view calls for firm managers to expand their skills, competences and information base in order to face competition (Prahalad \& Hamel, 1990; Sanchez, 2004); after all, these resources are more difficult for competitors to detect or copy (Gorman \& Thomas, 1997).

Penrose (2009) indicates that resources themselves are not enough inputs for firm operations but it is the way that these resources are used. Regarding managerial skills as a primary resource for firms (Wright et al., 2001) and a target area of development in food sector policy reforms (Dinh et al., 2013; HODECT, 2010), the skills can contribute to firm performance as long as they are in line with a firm's strategy (Edelman et al., 2005) and adequately used for designing and implementing firm strategies that properly reflect a firm's external situation and its internal resources (Grant, 2013). Therefore, we argue that direct relationship is not plausible unless there are strategic practices that play a key role in ensuring better utilization of resources to achieve performance. Therefore we hypothesize:

$H_{1}$ : Application of STM practices positively mediates the relationship between level of managerial expertise and firm performance.

As the firms operate in a dynamic competitive environment, there is more focus on developing human capital because it can sustain growth of the firm over time (McWilliams et al., 2001; Wright \& McMahan, 2011). Thus, there is a significant contribution to firm performance. In the agribusiness value chain, research shows that effect of manager/owners' level of skills is a crucial resource for firms (Boehlje et al., 
Chapter Three: Agribusiness Firm Resources and Performance: The Mediation Role of Strategic Management Practices

2011) as well as for firm performance (Cooper et al., 1994). Moreover, Hatten (2012) indicated that one of the factors causing a business failure is a lack of expertise of the owner and mostly in firm management. And in small firms, the managers are usually generalists because they have limited specialized management. He also explained, “...they (i.e. the managers) may not be able to afford to hire full-time experts who could help avert costly mistakes. On the other hand, their limited resources will not permit them to make mistakes and stay in business" (p. 16). Due to the fact that there is a considerable amount of literature that shows similar situations in small firm performance, there are strategies that call for management training programmes suitable for the needs of food processors (see HODECT, 2010).

$\mathrm{H}_{2}$ : In small firms, level of managerial skills is positively associated with firm performance.

There is a growing acceptance that people are strategically important among internal resources of firms (Wright et al., 2001). This is because their level of skills and expertise plays an important role in the achievement of firms' strategies (Barney, 1991; Díaz-Fernández et al., 2014). In small firms with a low number of employees, the manager's level of skills is crucial to the achievement of firms' strategies (Boehlje et al., 2011; Dominic \& Theuvsen, 2015). As top managers, they are solely responsible for the strategic direction of the firms (Grant, 2013). However, research indicates that managers from small food processing firms have poor ability to engage in strategic actions such as to calculate and anticipate cost of production to analyze the market conditions and consumer needs to set strategic prices etc. (Dietz et al., 2000). Some managers do not engage in the strategic management practices due to lack of skills and knowledge to engage themselves in the STM process (Beaver, 2007). Thus, if the managers receive more training in general firm operations, the firms are likely to increase the application of STM practices and improve the precondition for achieving their strategic objectives.

$H_{3}$ : An increase in managers' expertise is associated with an increase in the application of STM practices.

Access to market information in terms of data and knowledge can allow firms to understand competitors' actions, learn about customers' preferences and react effectively in order to have a smooth flow of their products (Hough \& White, 2004). However, access to information does not guarantee firm success; again, the ability to use it is 
Chapter Three: Agribusiness Firm Resources and Performance: The Mediation Role of Strategic Management Practices

crucial. The reason is that, even though human beings are intendedly rational, there are some limits to their abilities to process and use the information (Simon, 1957). Strategic behavior is also needed to improve the systematic use of information for decision making within a firm (Lieberman \& Asaba, 2006). In this case, we argue that the application of strategic management practices has a role in explaining the relationship between access to market information and firm performance.

$H_{4}$ : Application of STM practices positively mediates the relationship between access to market information and firm performance.

Contrary to that, other studies establish a direct link between access to information and agribusiness firm performance (Lwoga et al., 2011; Robert et al., 2011). The findings also indicate that quick and easy access to information satisfies the needs of the actors in the food supply chain. Other studies added that firms can improve their performance by just exploiting relevant information for the concerned market (Siyao, 2012). On the other side, poor access to information has been referred to as a potential constraint in agribusiness sector development (Elly \& Silayo, 2013; Siyao, 2012) particularly in small firms which are vulnerable to large competitors' actions. Therefore, firms that have more access to information can obtain competitive advantage over firms that do not (Nichter \& Goldmark, 2009).

$H_{5}$ : In small firms, access to market information is positively associated with firm performance.

Furthermore, firms are in a good position to understand the environment when they acquire information about raw materials, prices, competitors, customers, etc. As a result the firms may formulate strategies to buffer themselves against any threat that could cause trouble for the business (Hitt et al., 2009). Also the information can help firms to seek ways to respond to new opportunities (Nichter \& Goldmark, 2009). Through the information firms are more likely to be aware of existing products from other firms and come up with effective strategies to avoid falling behind their rivals (Lieberman \& Asaba, 2006).

$H_{6}$ : The more firms have access to market information, the more they apply STM practices. 
Chapter Three: Agribusiness Firm Resources and Performance: The Mediation Role of Strategic Management Practices

Firms have a chance of improving their performance levels through application of STM practices, for example through engaging in formulation of strategic plans, strategy implementation (Rudd et al., 2008) and environmental scanning (Bakar et al., 2011) just to mention a few. Other studies indicated that firms using STM tools achieved rapid growth in performance (Woods \& Joyce, 2003) and increase in sales and revenue (Andrews et al., 2009; Andrews et al., 2006; Beaver, 2002; Bracker \& Pearson, 1986; Georgellis et al., 2000). Hence including STM process in day to day business activities can help ensure firm survival and success (Stacey, 2011).

$H_{7}:$ The greater the extent of strategic management practices, the better the firm's performance.

Unfortunately, small firms have a tendency to avoid engaging in strategic planning due to their limited capital and poor knowledge of the process (Beaver, 2002). For example reports concerning agribusiness challenges have indicated that agribusiness firms in Tanzania fail to perform well in food markets due to poor utilization of market information, limited entrepreneurial capabilities and technical and managerial knowledge on manufacturing, low worker skills, poor operations logistics (Dinh et al., 2013) and a lack of ability to attract investors (Katera, 2009). Therefore, the reports imply that there is poor engagement in planning, implementation and control of firm strategies.

Our model as demonstrated in Figure 3-1 summarizes our review and discussion of the existing literature.

\section{Figure 3-1: Conceptual Model}

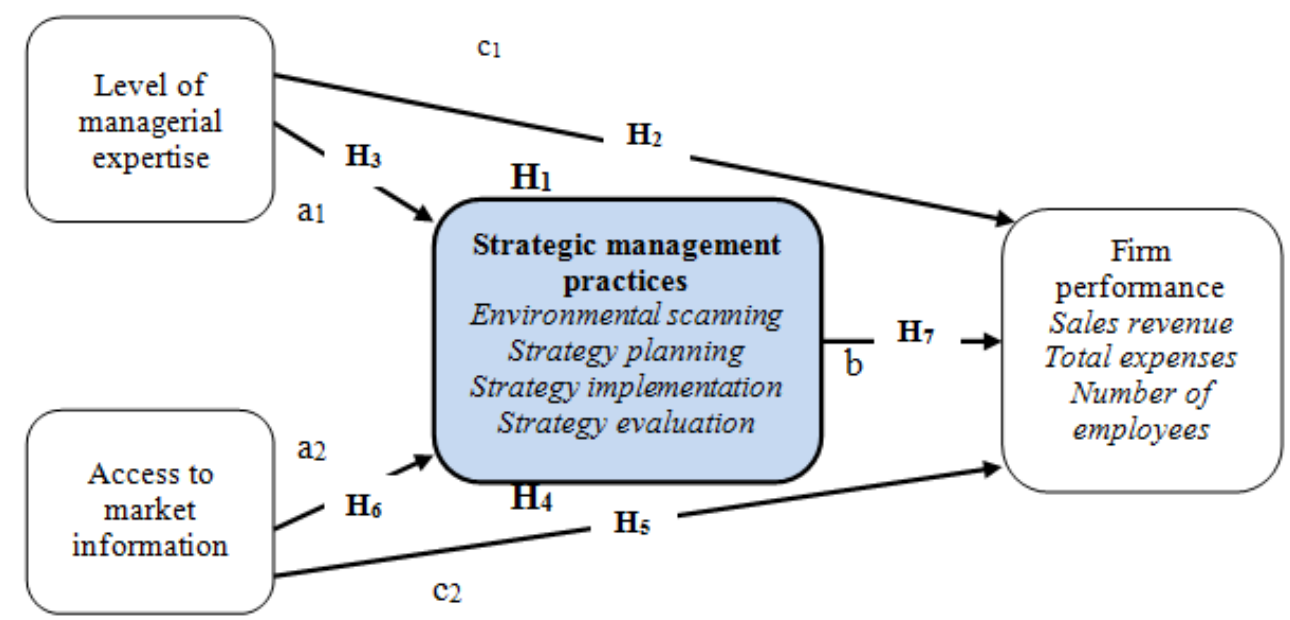

$\mathbf{a}_{\mathbf{x}}, \mathbf{b}_{\mathbf{x}}$ and $\mathbf{c}$ denote path coefficients for assessing structural model; $\mathbf{H}_{X}$ denotes research hypotheses

Source: Authors' illustration 
The food processing sector includes a large fraction of small businesses (NBS, 2012) which are quite different as they grow and develop. Chan et al. (2006) indicated that small firms have a tendency of developing their own managerial style and strategy as they seek to grow. In the process of achieving performance, the firms do not follow a single progression of development (Delmar et al., 2003). From a dynamic capability perspective, a firm may alter or renew its resources in order to increase its capacity in a rapidly changing environment (Teece, 2007).

Therefore, some firms may utilize a resource that fits its needs at the particular time. For example, a firm may either utilize external information in order to strategize according to competitors' actions; or utilize its skills and expertise in order to strategize against competitors' actions. This reflects the basic idea of equifinality. It says that firms can reach the same final state from different initial conditions and by a variety of paths (Gresov \& Drazin, 1997; Sinha \& Van de Ven, 2005). Therefore, we expect firms to behave differently regarding their management style, and the study will seek to uncover differences among firms to understand which ones behave differently in the use of firm resources.

\subsection{Methodology}

\subsubsection{Data Collection and Sample Description}

The study is a cross sectional survey conducted between May and August 2013. Data was collected through interviews with firm owner-managers with an aid of a structured questionnaire. The sample consists of firms dealing with food processing of cereals, vegetables and fruits, located in Arusha, Dodoma and Tanga regions in Tanzania. The selection of firms followed a random sampling technique from a list of processors from Small Industries Development Organization (SIDO). The organization deals with improving the effectiveness of small industries in the country. Over 331 firms were contacted and agreed to participate in the interviews; 229 questionnaires were qualified for analysis after excluding half-filled questionnaires. In general, the firms had a mean capital investment of 26.94 million TZS $\left(\approx 16,600\right.$ US $\$$ ) and an average of $7 \frac{1}{2}$ years of business operations. 
Chapter Three: Agribusiness Firm Resources and Performance: The Mediation Role of Strategic Management Practices

In the firms surveyed, there were three major types of products which are sold in processed forms; these were cereal products $(65.9 \%)$, followed by fruit products $(16.4 \%)$, vegetable products $(11.5 \%)$ and other $(6.2 \%)$. Almost all firms $(98.5 \%)$ buy farm produce from local farmers and only very few firms $(1.5 \%)$ import from neighboring countries. The respondents of this study were knowledgeable about general overview of the firm and cornerstones of their strategies. Their ages ranged from 18 to 78 years (average: 43 years), with an average of 11.05 years of school education. Table 3-1 shows additional details about the sample.

Table 3-1: Descriptive Information about the Sample (N=229)

\begin{tabular}{|c|c|c|c|c|}
\hline Variables & Mean & Std. Dev & Min & Max \\
\hline \multicolumn{5}{|l|}{ Information on Firm } \\
\hline Firm Age (yrs.) & 7.54 & 5.03 & 3 & 28.58 \\
\hline Full time employees & 5.00 & 3.41 & 3 & 20 \\
\hline Capital investment in million TZS & 26.94 & 51.81 & 0.3 & 350 \\
\hline Self-financed firms (d) & 0.27 & 0.40 & 0 & 1 \\
\hline Non-perishable products (d) & 0.66 & 0.48 & 0 & 1 \\
\hline Family business (d) & 0.26 & 0.44 & 0 & 1 \\
\hline \multicolumn{5}{|l|}{ Information on Respondent } \\
\hline Age & 43.00 & 10.70 & 18 & 78 \\
\hline Years of education (yrs.) & 11.05 & 3.51 & 1 & 22 \\
\hline Gender $(1=$ male $0=$ Female $)$ & 0.39 & 0.49 & 1 & 0 \\
\hline
\end{tabular}

(d) Dummy variable

\subsubsection{Measurement of Variables}

The study uses the primary data collection questionnaire survey technique to achieve its objective. Four constructs are used for the model estimation and they were measured using five point Likert scales to determine the extent to which respondents agree or disagree to each of the statements in the questionnaire. First, level of managers' expertise (EXP) was represented by 9 items. Second, access to market information (INFO) by 8 items and third, strategic management practices (STM) by 17 items divided into four dimensions, i.e. (a) environmental scanning, (b) strategic planning, (c) strategy implementation and (d) strategy evaluation. The STM measure was adopted from Wheelen and Hunger (2006)'s work. Fourthly, firm performance (PERF) was represented by 9 items in three dimensions, i.e. trends in revenue, total expenses and number of employees as adopted from the work of Remaud and Courdec (2006).

A descriptive analysis of the constructs used for our model estimation is presented in Appendix 3-1, which shows list of items, mean and standard deviation values. The 
Chapter Three: Agribusiness Firm Resources and Performance: The Mediation Role of Strategic Management Practices

data were analyzed using a second generation analysis technique referred as partial least square structural equation modelling (PLS-SEM) through smartPLS 2.0 M3 software (Ringle et al., 2005). It is a variance based SEM technique, non-parametric and appropriate for complex structural models. The technique analyses relationships represented in path diagrams that include a web of observed and unobserved variables, whereby a dependent variable in one path can become an independent variable in another path (Hair et al., 2014), whilst in regression models, there exists a clear distinction between dependent and independent variable.

\subsubsection{Model Estimation}

In estimating the PLS path models, a two-step analysis is carried out to assess the quality of model results: measurement model analysis and structural model analysis. The measurement model is used to assess the relationships between indicators and constructs, while the structural model measures the relationships between the constructs. From the measurement model analysis, we assess the validity and reliability of the items of each construct (see Table 3-2). Regarding the reliability of items, all standardized loadings were significant at the 0.01 level and exceeded the threshold level of 0.708 (Hulland, 1999); however the rule is not rigidly applied to early stages of research hence two items in the 'INFO' construct which were above 0.588 were retained (Hair et al., 2010). Items with low loading below 0.5 were deleted because they were regarded as unreliable.

To check for convergent validity, almost all Average Variance Extracted (AVE) values were above the threshold of 0.5 (Fornell \& Larcker, 1981; Hair et al., 2010). The AVE value for INFO variable was kept because it was close to the threshold value. To check for the internal consistency reliability of the items, each latent variable's Composite Reliability (CR) and Cronbach's alpha $(\alpha)$ values were evaluated (see Table $3-2$ ); the values were above their thresholds of 0.6 and 0.7 respectively (Nunnally, 1978). In PLS structural equation models CR values provides more robust measures of reliability than the alpha values, however the difference is inconsequential (see the comparison in Peterson \& Kim, 2013). Therefore, the measures have adequate levels of convergent validity and internal consistency reliability. 
Chapter Three: Agribusiness Firm Resources and Performance: The Mediation Role of Strategic Management Practices

Table 3-2: PLS Model Quality Criteria

\begin{tabular}{lrrrr} 
& Loadings & AVE & CR & Cronbach $\boldsymbol{\alpha}$ \\
\hline EXP (Level of expertise of the manager) & & 0.642 & 0.899 & 0.860 \\
\hline EXP_1 & 0.749 & & & \\
EXP_2 & 0.833 & & & \\
EXP_3 & 0.846 & & & \\
EXP_6 & 0.787 & & & 0.741 \\
EXP_8 & 0.786 & & & \\
\hline INFO (Information Access) & & 0.497 & 0.830 & \\
\hline INFO_2 & 0.655 & & & \\
INFO_4 & 0.800 & & & \\
INFO_5 & 0.794 & & & \\
INFO_6 & 0.665 & & & \\
INFO_7 & 0.588 & & & \\
\hline PERF (Firm Performance) & & 0.680 & 0.864 & \\
\hline REV_1a & 0.770 & & & \\
REV_1b & 0.875 & & & \\
REV_1c & 0.826 & & & \\
\hline STM (Strategic management practices) & & 0.867 & 0.963 & \\
\hline STM_A & 0.926 & & & \\
STM_B & 0.930 & & & \\
STM_C & 0.933 & & & \\
STM_D & 0.936 & & & \\
\hline
\end{tabular}

Note: $A V E$; Average Variance Extracted, $C R$; Composite Reliability

In addition, in Table 3-3 discriminant validity is confirmed through the application of the Fornell-Larcker criterion (Fornell \& Larcker, 1981). The criterion is met when the square root of the AVE of each construct is higher than the construct's highest correlation with any other construct in the model. The cross loadings report is presented in Appendix 3-2. Moving across the rows reveals that each item loads higher on its respective construct than on any other construct. The report further verifies discriminant validity.

Table 3-3: Fornell-Larcker Criteria

\begin{tabular}{lcccc}
\hline & EXP & INFO & PERF & STM \\
\hline EXP & $\mathbf{0 . 8 0 1}$ & & & \\
INFO & 0.494 & $\mathbf{0 . 7 0 5}$ & & \\
PERF & 0.384 & 0.377 & $\mathbf{0 . 8 2 5}$ & \\
STM & 0.538 & 0.478 & 0.581 & $\mathbf{0 . 9 3 1}$ \\
\hline
\end{tabular}

From the structural model analysis, we check if there is a multicollinearity problem. SPSS software is used to run this test to check for the Variance Inflation Factor (VIF) values. Results show that the values are below the threshold value of 5.0 hence indicating no multicollinearity problem among predictor variables (see Appendix 3-3). The variance explained by the model $\left(\mathrm{R}^{2}\right)$ is also a criterion for evaluating the structural model. The $\mathrm{R}^{2}$ for STM and PERF constructs are 34.9 and 35.3 per cent respectively, 
Chapter Three: Agribusiness Firm Resources and Performance: The Mediation Role of Strategic Management Practices

meaning that the independent variables in the model explain 34.9 percent of the variation in STM and 35.3 percent of the variation in PERF. Moreover, results from $f^{2}$ and $q^{2}$ values (see Appendix 3-4) indicate that all values are above zero hence there is an impact of the predictor variables on their target variables, as well as predictive relevance.

After the two-step analysis for verifying reliability and validity of our measures, we present results of path relationships in the structural model. Thereafter, the results from the structural model are used to conduct mediation analysis for testing hypotheses $\mathrm{H}_{1}$ and $\mathrm{H}_{4}$. Finally, a multigroup analysis is conducted to uncover heterogeneity within our sample, with the application of FIMIX-PLS technique (Hahn et al., 2002; Sarstedt et al., 2011).

\subsection{Results}

\subsubsection{PLS Structural Equation Model Analysis}

Figure 3-2 shows the visual results while Table 3-4 shows detailed results of the relationships between variables, path coefficients, R-squared, t-values and p-values. Significance of the path coefficients was determined via a bootstrapping procedure, where the sample size was increased to 5,000. The results show that level of managerial skills and access to market information are positively associated with an application of STM practices $\left(\mathrm{H}_{3} ; 0.399 * * *\right.$ and $\left.\mathrm{H}_{6} ; 0.281 * * *\right)$ and both explain 34.9 percent of the variation in the application of STM practices.

Table 3-4: Path Coefficients and Significance Testing

\begin{tabular}{llcrrrll}
\hline $\begin{array}{l}\text { Path } \\
\text { Relationships }\end{array}$ & Path & $\begin{array}{c}\text { Path } \\
\text { Coeff. }\end{array}$ & t-Values & $\begin{array}{c}\text { p- } \\
\text { Values }\end{array}$ & $\begin{array}{l}\text { Sig. } \\
\text { Hypot } \\
\text { hesis }\end{array}$ & Decision \\
\hline EXP $\rightarrow$ PERF & $\mathbf{c}_{1}$ & 0.064 & 0.570 & 0.284 & & $\mathrm{H}_{2}$ & Not supported \\
EXP $\rightarrow$ STM & $\mathbf{a}_{1}$ & 0.399 & 4.139 & 0.000 & $* * *$ & $\mathrm{H}_{3}$ & Supported \\
INFO $\rightarrow$ PERF & $\mathbf{c}_{2}$ & 0.109 & 1.115 & 0.132 & & $\mathrm{H}_{5}$ & Not supported \\
$\mathrm{INFO} \rightarrow$ STM & $\mathbf{a}_{2}$ & 0.281 & 2.917 & 0.002 & $* * *$ & $\mathrm{H}_{6}$ & Supported \\
$\mathrm{STM} \rightarrow$ PERF & $\mathbf{b}$ & 0.495 & 5.097 & 0.000 & $* * *$ & $\mathrm{H}_{7}$ & Supported \\
\hline
\end{tabular}

\begin{tabular}{lccccc}
\hline \multicolumn{2}{l}{ Relationship without STM as a mediator } & \multicolumn{3}{c}{ (Ringle et al., 2012) } \\
\hline EXP $\rightarrow$ PERF & $\mathbf{c}_{1 \mathbf{x}}$ & 0.399 & 5.118 & 0.000 & $* * *$ \\
INFO $\rightarrow$ PERF & $\mathbf{c}_{2 \mathbf{x}}$ & 0.382 & 7.130 & 0.000 & $* * *$ \\
\hline & $* * * \mathrm{p}<0.01, \mathrm{t}$ value $>2.327 ; * * \mathrm{p}<0.05, \mathrm{t}$ value $>1.645 ;$ and $* \mathrm{p}<0.1, \mathrm{t}$ value $>1.282$
\end{tabular}


Chapter Three: Agribusiness Firm Resources and Performance: The Mediation Role of Strategic Management Practices

In turn, the greater the extent of STM application the better the firm performance $\left(\mathrm{H}_{7} ; 0.495^{* * *}\right)$. The model explains 35.3 percent of the variation in firm performance. However, the influences of managers' level of expertise and access to information on firm performance were not significant $\left(\mathrm{H}_{2} ; 0.064\right.$ and $\left.\mathrm{H}_{5} ; 0.109\right)$ which is contrary to what is frequently indicated in the literature. The influence might be brought by mediation effect hence we proceed with $\mathrm{H}_{1}$ and $\mathrm{H}_{4}$ testing in Section 4.2.

\section{Figure 3-2: Results of the PLS Model}

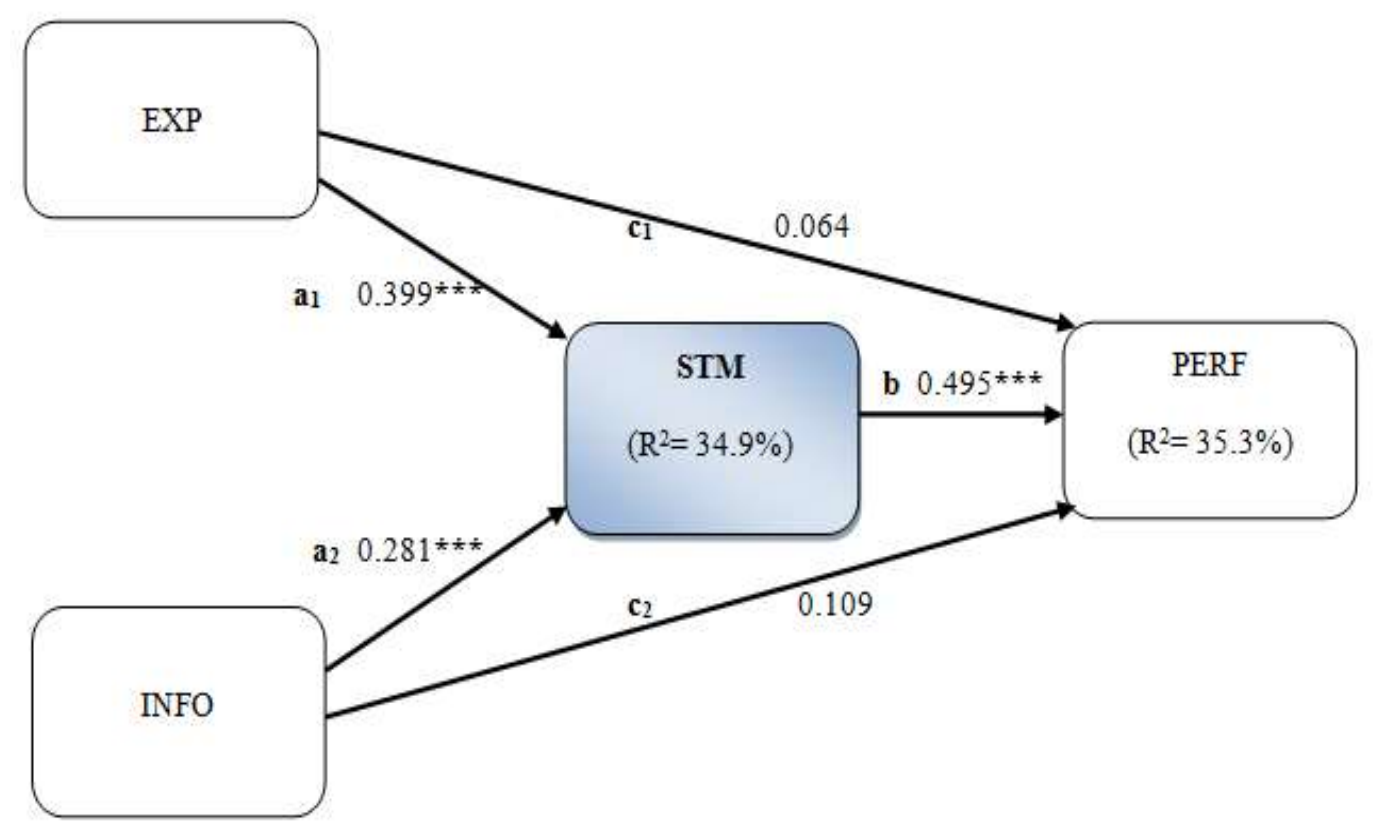

Source: Authors' calculations Significance $* * * \mathrm{p}<0.01, \mathrm{t}$ value $>2.327 ; * * \mathrm{p}<0.05, \mathrm{t}$ value $>1.645 ; * \mathrm{p}<0.1$ and $t$ value $>1.282$.

\subsubsection{Mediator Analysis}

Mediation in path models can be assessed by examining the relationship of the direct link between two latent variables and the indirect link via the potential mediator variable. From our model, two paths are assessed: first, EXP $\rightarrow$ PERF relationship via STM and second, INFO $\rightarrow$ PERF relationship via STM (see Figure 3-2). In the first case mediation can be assumed if the following conditions are met (see Baron \& Kenny, 1986; Hayes, 2012):

(a) Variations in EXP levels significantly account for variations in the mediator STM, i.e. path $\mathrm{a}_{1}$. 
Chapter Three: Agribusiness Firm Resources and Performance: The Mediation Role of Strategic Management Practices

(b) Variations in STM as a mediator significantly account for variations in PERF, i.e. path $b$.

(c) When paths $\mathrm{a}_{1}$ and $\mathrm{b}$ are controlled, path $\mathrm{c}_{1}$ is no longer significant.

All the conditions in the first case are met because with reference to Table 3-4, path $a_{1}$ and path $b$ are significant. When the STM variable is removed from the model, path $c_{1}$ has a value of $\beta=0.399$, $t$-value $=5.118$. Oppositely, when it is included in the model, path $c_{1}$ is not significant $(\beta=0.064, t-v a l u e=0.570)$. Next, we test for significance of the mediation to find support for $\mathrm{H}_{1}$. Indirect effect of the relationship between EXP and PERF is 0.198 , which is a product of paths $\mathrm{a}_{1}$ and $\mathrm{b}$ (i.e. $\left.0.399 \times 0.495\right)$. Thereafter, the $\mathrm{t}-$ value is determined by running a nonparametric bootstrapping procedure (Preacher \& Hayes, 2008). The results show that the t-value is 2.955; thus, the mediation effect is significant at the 0.01 level. Therefore, $\mathrm{H}_{1}$ is supported.

In the second case, all conditions are met because path $\mathrm{a}_{2}$ and path $\mathrm{b}$ are significant but when the STM variable is removed from the model, path $c_{2}$ has a value of $\beta=0.382$, $t$ value $=7.130$. Oppositely, when STM is included again in the model, path $\mathrm{c}_{2}$ is no longer significant $(\beta=0.109, \mathrm{t}$-value=1.115). Next, we test for significance of the mediation in order to test for $\mathrm{H}_{4}$. The indirect effect of the relationship between INFO and PERF is 0.139 , which is a product of paths $\mathrm{a}_{2}$ and $\mathrm{b}(0.281 \times 0.495)$. Next the $\mathrm{t}$-value is determined by again running a nonparametric bootstrapping procedure (Preacher \& Hayes, 2008). The results reveal that the $\mathrm{t}$-value is $2.473, \mathrm{p}=0.013$, hence that the mediation effect is significant at $\mathrm{p}=0.05$ level. Therefore, $\mathrm{H}_{4}$ is supported indicating the role of STM as a mediator.

The next step is to check for the strength of mediation in the two relationships in order to convey its practical significance. VAF (Variance Accounted For) is an index that measures the strength by calculating the ratio of an indirect effect through a mediator to a total effect (Shrout \& Bolger, 2002). With reference to path coefficients indicated in Figure 3-2 and Table 3-4, the following formula is used:

$\operatorname{VAF}=\left(a_{x}+b\right) /\left(a_{x} b+c_{x}\right)$ 
Chapter Three: Agribusiness Firm Resources and Performance: The Mediation Role of Strategic Management Practices

Table 3-5: Strength of Mediation

\begin{tabular}{llll}
\hline $\begin{array}{c}\text { Path Relationships }\left(\mathbf{H}_{\mathbf{4}} \text { and } \mathbf{H}_{\mathbf{4}}\right. \\
\text { EXP } \rightarrow \text { PERF path via STM }\end{array}$ & VAF & Result \\
\hline & $=\frac{a_{1} \cdot b}{a_{1} \cdot b+c_{1}}$ & $\begin{array}{l}\text { Partial } \\
\text { mediation }\end{array}$ \\
& $=\frac{0.399 \times 0.495}{\mathbf{H}_{\mathbf{1}} \cdot b+c_{2}}$ & $\mathbf{7 5 . 4 \%}$ & \\
\hline INFO $\rightarrow$ PERF path via STM & & $0.495+0.064$ & $\begin{array}{l}\text { Partial } \\
\text { mediation }\end{array}$ \\
& $=\frac{0.281 \times 0.495}{0.281 \times 0.495+0.109}$ & & \\
& &
\end{tabular}

Note:

VAF $>80 \%=$ Full Mediation, $20 \% \leq \mathrm{VAF} \leq 80 \%=$ Partial Mediation and $\mathrm{VAF}<20 \%=$ No Mediation

Table 3-5 indicates that there is a partial mediation effect, i.e. STM mediates the relationships between EXP and PERF by 75.4 percent and between INFO and PERF by 56 percent. The STM would have to be above 80 percent value to qualify as a full mediator between the relationships. Full mediation would have suggested that the application of STM practices is the only tool or method that helps managers align their resources to achieve firm performance. Since there are several variables (not included in this study) that can help firms to increase performance it is unrealistic to expect that a single mediator would completely explain the effect of firm resources on firm performance.

\subsubsection{Multigroup Analysis}

Our next step is to investigate unobserved differences among firms to see whether different variable estimates occur for each group. Our approach is to apply a latent class analysis technique known as finite mixture PLS technique (FIMIX-PLS) from the smartPLS 2.0 M3 software (Hahn et al., 2002; Sarstedt et al., 2011). The technique is ideal for PLS path models and used to identify unobserved heterogeneity in our sample by producing homogenous segments according to the significant relationships that exist within a segment. FIMIX-PLS algorithm is run sequentially for several models, i.e. $K=2$, 3 , and 4; the results are presented in Table 3-6. 
Chapter Three: Agribusiness Firm Resources and Performance: The Mediation Role of Strategic Management Practices

Table 3-6: FIMIX-PLS evaluation criteria and relative segment sizes

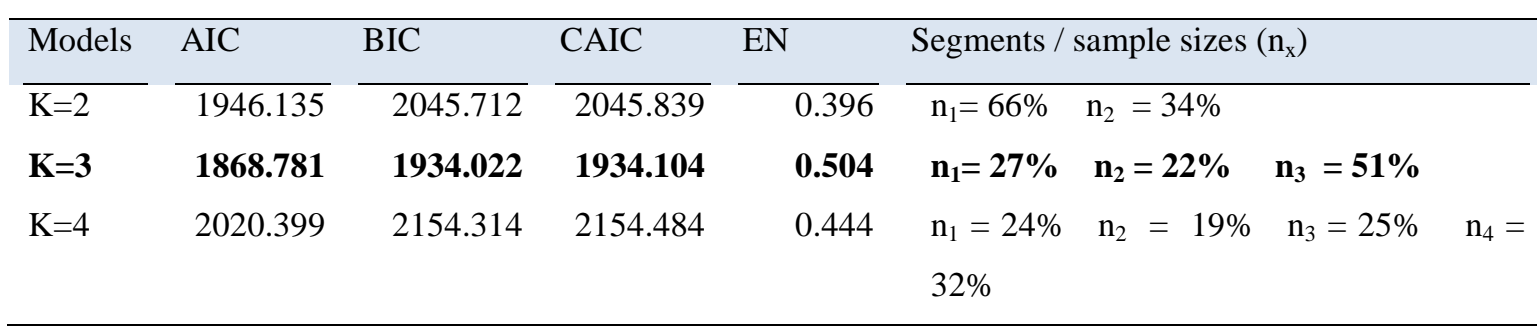

Note:

$\mathrm{K}=$ Number of sub-groups or segments.

Criteria; Akaike's information criterion (AIC); Consistent AIC (CAIC); and Bayes information criterion (BIC).

The results in Table 3-6 justify a selection of ' $\mathrm{K}=3$ ' model. Evaluation criteria for this selection involve lowest values of Akaike's information criterion (AIC), consistent AIC (CAIC), Bayesian information criterion (BIC) and highest values of entropy measure (EN) (Ringle et al., 2010; Sarstedt et al., 2011). The selected three segment model (i.e. $K=3$ ) indicates segment sizes of $n_{1}=27 \%, n_{2}=22 \%$ and $n_{3}=51 \%$. However, ex-post analysis is carried out and the segment sizes are redistributed to $\mathrm{n}_{1}=22 \%, \mathrm{n}_{2}=22 \%$ and $\mathrm{n}_{3}=56 \%$ according to best probabilities of segment membership. Thereafter, PLS algorithm is run separately for segments 1,2 and 3 and the results of estimates for each path are presented in Table 3-7.

Table 3-7: Path Coefficients for each segment

\begin{tabular}{|c|c|c|c|c|}
\hline & \multirow{2}{*}{$\begin{array}{c}\text { Overall } \\
\text { (full model) }\end{array}$} & \multicolumn{3}{|c|}{ Classes/segments $\mathrm{K}=3$} \\
\hline & & Segment 1 & Segment 2 & Segment 3 \\
\hline $\mathrm{EXP} \rightarrow \mathrm{PERF}$ & 0.064 & $0.685 * * *$ & $-0.573 * * *$ & $0.096 *$ \\
\hline $\mathrm{EXP} \rightarrow \mathrm{STM}$ & $0.400 * * *$ & $-0.177 * *$ & $0.314 * * *$ & $0.519 * * *$ \\
\hline INFO $\rightarrow$ PERF & 0.109 & $-0.797 * * *$ & $0.604 * * *$ & $0.219 * * *$ \\
\hline $\mathrm{INFO} \rightarrow \mathrm{STM}$ & $0.281 * * *$ & $0.876 * * *$ & $0.682 * * *$ & -0.073 \\
\hline STM $\rightarrow$ PERF & $0.495 * * *$ & $\mathbf{0 . 5 5 2} * * *$ & $0.716 * * *$ & $0.706 * * *$ \\
\hline $\mathrm{R}^{2}(\mathrm{STM})$ & 0.349 & 0.565 & 0.822 & 0.257 \\
\hline $\mathrm{R}^{2}(\mathrm{PERF})$ & 0.353 & 0.299 & 0.944 & 0.649 \\
\hline Sample size & $\mathrm{N}=229$ & $\mathrm{n}_{1}=50$ & $\mathrm{n}_{2}=50$ & $\mathrm{n}_{3}=29$ \\
\hline
\end{tabular}

Note:

$\mathrm{N}=$ Full model, $\mathrm{n}=$ segment size; Path coefficient significant at $* * * \mathrm{p}<0.01 ; * * \mathrm{p}$ $<0.05$ and $* \mathrm{p}<0.1$

Discriminant validity and reliability measures are verified for each segment (see Appendix 3-5)

Test for significant differences between segments are indicated in Appendix 3-7 
Table 3-7 also shows that while level of managers' expertise emerges as the main driver to increasing firm performance in the first segment $\left(\mathrm{n}_{1}=50\right)$, access to market information looms as the key driver in the second segment $\left(\mathrm{n}_{2}=50\right)$. However, in the third segment $\left(\mathrm{n}_{3}=129\right)$, application of STM practices has a stronger effect on firm performance than access to market information and level of managers' expertise. Furthermore, in segment 3 level of managers' expertise and market information are weak drivers of firm performance. Again, mediation analysis was conducted for each subgroup (or segment). Results show that STM was neither a potential mediator in segment 1 nor in segment 2 . The mediation effect was only detected in segment 3 , with a VAF value of $0.792 \approx 79 \%(\mathrm{t}=6.395)$. Therefore, the value provides evidence for a (strong) partial mediation in segment 3 (significant at the 0.01 level). Appendix 3-7 presents details for significance test for groups' differences between the paths coefficients.

The effect of managers' expertise on firm performance is positive $\left(0.685^{* * *}\right)$ in segment 1 but negative in segment $2\left(-0.573^{* * *}\right)$ and weak in segment $3\left(0.096^{*}\right)$. The results reveal mixed effects of expertise on firm performance as argued earlier in the literature (see Boehlje et al., 2011 and Edelman et al., 2005). Also, the effect of market information on firm performance in segment 1 is strongly negative $(-0.797 * * *)$, whereas it is strongly positive in segment $2(0.604 * * *)$. In segment 3 there is a weak relationship between access to market information and firm performance $(0.219 * * *)$. Similar to the findings regarding managerial expertise, the results reveal mixed effects of market information on firm performance. Interestingly, there were no mixed effects regarding the effect of STM application on firm performance, i.e. the application of strategic management practices was strongly positive in segments 1,2 and 3.

\section{Table 3-8: Summary of Path Relationships for each Segment}

\begin{tabular}{|c|c|c|c|}
\hline \multirow[b]{2}{*}{ Path Relationships } & \multicolumn{3}{|c|}{ Path Coefficients } \\
\hline & $\begin{array}{c}\text { Segment } 1 \\
\text { human capital } \\
\text { oriented firms }\end{array}$ & $\begin{array}{c}\text { Segment } 2 \\
\text { information } \\
\text { dependent firms }\end{array}$ & $\begin{array}{c}\text { Segment } 3 \\
\text { strategic-oriented } \\
\text { firms }\end{array}$ \\
\hline $\begin{array}{l}\text { Level of managers' expertise } \rightarrow \text { firm } \\
\text { performance }\end{array}$ & Strong positive & Strong negative & Weak \\
\hline $\begin{array}{l}\text { Access to market information } \rightarrow \text { firm } \\
\text { performance }\end{array}$ & Strong negative & Strong positive & Weak \\
\hline $\begin{array}{l}\text { Strategic management practices } \rightarrow \text { firm } \\
\text { performance }\end{array}$ & Strong positive & Strong positive & Strong positive \\
\hline
\end{tabular}


Chapter Three: Agribusiness Firm Resources and Performance: The Mediation Role of Strategic Management Practices

Table 3-8 shows a summary of characteristics of each segment. The three segments can be depicted as follows:

(a) Segment 1 consists of agribusiness firms that are characterized by a strong positive relationship between level of managers' expertise and firm performance and a negative relationship between access to market information and firm performance. Since the variable "level of managerial expertise (EXP)" is the major driver of firm performance among the exogenous variables, we name this segment as human capital oriented firms. Further details from descriptive statistics indicate that these firms have more years of experience in food processing than firms in segments 2 and 3. Also, the firms are able to make more use of business management tools such as balance sheet, profit and loss statement, cash flow, performance appraisal, risk analysis and SWOT analysis than the firms in segments 2 and 3 (Appendix 3-8).

(b) Segment 2 consists of agribusiness firms that are characterized by, on the one hand, a strong positive relationship between access to market information and firm performance and, on the other hand, a negative relationship between level of managerial expertise and firm performance. Such firms function best with the collection of information from external sources, such as information on raw materials, sales channels, prices and customers' preferences. The negative link between managerial expertise and performance may imply that firms' revenues decrease as they spend much either on training costs or on hiring skilled labour, hence the firms put more efforts in collecting market information and work best using information databases. In this group, "access to market information" is the major resource that contributes to firm performance; hence we denote this segment as information dependent firms. Appendix 3-8 indicates further details on descriptive statistics.

(c) Segment 3 consists of agribusiness firms that reveal a weak relationship between level of managers' expertise and firm performance as well as a weak relationship between access to market information and firm 
performance. The application of STM practices has the strongest effect on firm performance and the contribution from managerial skills to firm performance is mediated by strategic management practices (unlike firms in segments 1 and 2). These firms rely primarily on long term planning with a clear purpose and direction they intend to go. The firms constantly engage in strategy planning, implementation and evaluation activities to ensure that their objectives are achieved (for example, increase in revenues, sales, etc.). Since the variance in firm performance is explained best through the application of STM, this segment is named as strategic-oriented firms. Appendix 3-8 gives further details on descriptive statistics.

In general, there were no significant differences found between segments in relation to socio-demographic characteristics such as age of the firm manager, gender of the firm owner, education level, etc. (Appendix 3-8).

\subsection{Discussion and Conclusions}

Most firms competing within a similar environment are assumed to possess similar types of resources, hence they are challenged to compete with other firms in their pursuit of increasing performance. This study shows that engaging in strategic management practices enables firms to perform better and strengthen its competitive position and financial performance. The findings were established by including an intervening variable in a model by using the mediating analysis procedure suggested by Baron and Kenny (1986). This is because the relationship between access to resources and firm performance could be better justified via the consideration of STM as a mediating variable.

The resources such as level of managerial skills and access to market information are not necessarily directly associated with firm performance $\left(\mathrm{H}_{2}\right.$ and $\mathrm{H}_{5}$ are not supported) but related to firm performance via the application of STM practices $\left(\mathrm{H}_{1}\right.$ and $\mathrm{H}_{4}$ are supported). The results support and explain further the previous studies by Penrose $(1959,2009)$ that resources are not enough as inputs for firm operations but that it is rather the way that these resources are used. It is even more advantageous when the resources, for instance the capabilities of managers, are in line with a firm's strategy 
Chapter Three: Agribusiness Firm Resources and Performance: The Mediation Role of Strategic Management Practices

(Edelman et al., 2005). Moreover, we suggest that the skills achieved from formal education are not essentially translated into practical use on business management tools. It is about going extra miles to create effective strategies. One of the incidences is that the agro-processing sector in the country under analysis, i.e. Tanzania, has been characterized by its inability to gain sustained revenues by constant selling of primary products and its inability to attract venture capitalists as a result of poor plans and poor record keeping (Dinh et al., 2013). A number of firms have been operating without proper business plans and workers literally operate blindly with poor knowledge on future business directions. This situation should alert policy makers to focus more on improving managerial style and capabilities particularly through promoting STM training.

Results also indicate that access to market information as such is not necessarily helpful for firm performance, because human beings have different abilities to process information. The results support Simon's (1957) work on humans' limited ability to process information but differ from other studies such as Lwoga et al. (2011) and Elly and Silayo (2013) which discussed importance of information for farmers while making implications for all actors in the agricultural sector and offered no explanation on what to do with the information. In our study, we involve food processors who are mostly closer to the final consumer and suggest that the information alone might not be significant for a firm's survival, but that information is better utilized if it is aligned with a firm's strategy. In some cases, firms can receive timely information about overall market conditions but the managers require an analytic mind to link the information to their firms' strategic actions. Without doing so, the access to market information alone might not be relevant to achieve firm performance and sustainable competitive advantage as suggested by Barney \& Hesterly (2010). Transforming the agribusiness sector commercially is very complex; managers need to have access to information to cope with rapidly changing markets. The study results show that the information should be brought in line with strategic actions to enhance performance, and that is when the role of STM practices comes in.

Furthermore, our findings show the importance of identifying a fit between resources and strategic management practices in the context of small firms. Since small firms operate in a dynamic environment and are faced with severe constraints regarding economic and technical resources (Dinh et al., 2013), the firm managers should keep in 
Chapter Three: Agribusiness Firm Resources and Performance: The Mediation Role of Strategic Management Practices

mind that strategic orientation matters. Incorporating strategic management tools is considered as a building block to managerial decisions and actions, which is also consistent with Porter's (1985) view on firm growth and strategy and Barney's (2001) work on finding a relationship between resources and strategies. Managers have to carefully utilize the strengths of their firms' resources and develop related strategies to gain high returns. Our recommendation takes into account recent structural reforms in promoting the agribusiness sector (IFAMR, 2014) and Tanzania's specific initiatives in enhancing specialized managerial training (see Tanzania Integrated Industrial Development Strategy 2025) in MOIT (2011) report. The reason is that small firms which engage in strategic management practices outperform those that do not. In this case, policy makers should take the engagement into consideration while developing an action plan that includes capacity building initiatives on strategic planning and management.

This study has both academic and practical implications. It adds to the academic literature that resources alone are not likely to contribute to firm performance if they are not aligned with firms strategies (Edelman et al., 2005; Edelman \& Brush, 2001). The key resources of the firms are effective when balanced with the firms' plans indicated in either mission, vision statement, business plan or firms' objectives. With this regard, managers are encouraged to choose resources that work best for their particular firms. Generally, our work contributes to the development of competency-based competition (Prahalad \& Hamel, 1990) which calls for further expansion of specialized knowledge and skills that have 'value' to the firms' objectives. From the practical perspective, the managers can understand in more detail why some firms achieve their objectives while others do not in the presence of the same type of resources and similar business environments. The study implies that promoting strategic behavior is beneficial to small firms as well (Beaver, 2007) and that investing in training programmes for human capital development will have an impact on increase in sales and revenues (Byerlee et al., 2013). It does not mean that the formal class trainings and complex procedures are necessary at all times. The essential element is to develop a strategic plan that is understood and communicated to every worker in the firm. Thus, the firms will be able to employ or develop a person with a desirable skill or collect appropriate information from the external market. 
Care must be taken in order to avoid over-generalizing these results because further investigations from multigroup analysis indicate that our recommendations might not fit all types of firms. Small firms are different and their paths to achieve sustainable growth are diverse (Chan et al., 2006). There are firms which depend more on managers' expertise and less on market information to achieve firm performance (human capital oriented firms), whereas other firms rely more heavily on access to relevant information (i.e. information dependent firms). A third type of firms showed that a direct link between resources and performance is weak but the influence of the application of STM practices is strong (strategic-oriented firms). However, in all groups results revealed positive effects of the application of STM on financial performance. This implies that even though the firms are different in their strategies, they end up more similar in the way they achieve performance (equifinality; Gresov \& Drazin, 1997; Sinha \& Van de Ven, 2005).

Our findings are in line with Chan et al.'s (2006) suggestion that even though there are heterogeneous paths to sustainable growth, firms end up more similar to each other than they were when they started. Therefore, regardless of whether a firm is characterized as human-capital oriented, information-dependent or strategic oriented (see Table 3-8), they follow similarly successful paths to performance as they grow. Furthermore, the differences are regardless of age of the firm manager, gender of the firm owner and other firm characteristics (see Appendix 3-8) which shows that a path of success for one firm might not apply to the other.

This study faced some limitations in terms of scope because it focused mainly on a sample of agribusiness firms dealing with processed food products (cereals, fruits and vegetables) in three regions of Tanzania. An interesting extension would be to include other external resources to examine their influence on firm performance via strategic management practices. For the purpose of generalization, future studies may also want to include both large and small firms in Tanzania and beyond to broaden the scope of the study and improve its representativeness. Finally, the inclusion of resources other than level of managerial expertise and access to information in strategic actions as well as more complex combinations of resources might help to offer a deeper understanding on alternative pathways to improve firm performance. 


\section{References}

Admassie, A., \& Matambalya, F. A. S. T. (2002). Technical efficiency of small and medium scale enterprises: Evidence from a survey of enterprises in Tanzania. Eastern Africa Social Science Research Review, 18(2), 1-29.

Ambrosini, V., \& Bowman, C. (2009). What are dynamic capabilities and are they a useful construct in strategic management? International Journal of Management Reviews, 11(1), $29-49$.

Andrews, R., Boyne, G. A., Law, J., \& Walker, R. M. (2009). Strategy formulation, strategy content and performance: An empirical analysis. Public Management Review, 11(1), 1-22.

Andrews, R., Boyne, G. A., \& Walker, R. M. (2006). Strategy content and organizational performance: An empirical analysis. Public Administration Review, 66(January-February), $52-63$.

Bakar, A., Tufail, M. A., Yusof, M. N., \& Virgiyanti, W. (2011). Implementation of strategic management practices in the Malaysian construction industry. Pakistan Journal of Commerce and Social Sciences, 5(1), 140-154.

Bakker, H. (2011). Food security in Africa and Asia: Strategies for small-scale agricultural development (p. 247). Cambridge, MA, USA: CAB International.

Barney, J. B. (1991). Firm resources and sustained competitive advantage. Journal of Management, 17(1), 99-120.

Barney, J. B. (2001). Is the resource-based "view" a useful perspective for strategic management research? Yes. Academy of Management Review, 26(1), 41-56.

Barney, J. B., \& Hesterly, W. S. (2010). Strategic management and competitive advantage concepts. Upper Saddle River, NJ: Pearson Prentice Hall.

Baron, R. M., \& Kenny, D. A. (1986). The moderator-mediator variable distinction in social psychological research: Conceptual, strategic and statistical considerations. Journal of Personality and Social Psychology, 51(6), 1173-1182.

Beaver, G. (2002). Strategy and Management in the Smaller Enterprise. Strategic Change, 11(4), $175-181$.

Beaver, G. (2007). The strategy payoff for smaller enterprises. Journal of Business Strategy, 28(1), 11-17.

Becker, B. E., Huselid, M. A., \& Ulrich, D. (2001). The HR scorecard: Linking people, strategy, and performance. Boston, MA: Harvard Business School Press.

Bloom, N., \& Van Reenen, J. (2007). Measuring and explaining management practices across firms and countries. The Quarterly Journal of Economics, 122(4), 1351-1408.

Boehlje, M., Roucan-Kane, M., \& Bröring, S. (2011). Future agribusiness challenges: Strategic uncertainty, innovation and structural change. International Food and Agribusiness Management Review, 14(5), 53-82. 
Chapter Three: Agribusiness Firm Resources and Performance: The Mediation Role of Strategic Management Practices

Bracker, J. S., \& Pearson, J. N. (1986). Planning and financial performance of small, mature firms. Strategic Management Journal, 7(6), 503-522.

Byerlee, D., Garcia, A. F., Giertz, A., \& Palmadesa, V. (2013). Growing Africa: Unlocking the potential of agribusiness. The World Bank. Retrieved August 17, 2014, from http://documents.worldbank.org/curated/en/2013/03/17427481/ growing-africa-unlockingpotential-agribusiness-vol-1-2-main-report

Chan, Y. E., Bhargava, N., \& Street, C. T. (2006). Having arrived: The homogeneity of highgrowth small firms. Journal of Small Business Management, 44(3), 426-440.

Cooper, A. C., Gimeno-Gascon, F. J., \& Woo, C. Y. (1994). Initial human and financial capital as predictors of new venture performance. Journal of Business Venturing, 9(5), 371-395.

Delmar, F., Davidsson, P., \& Gartner, W. B. (2003). Arriving at the high-growth firm. Journal of Business Venturing, 18(2), 189-216.

Díaz-Fernández, M., López-Cabrales, A., \& Valle-Cabrera, R. (2014). A contingent approach to the role of human capital and competencies on firm strategy. Business Research Quarterly, $17(3), 205-222$.

Dietz, M. H., Matee, S., \& Ssali, W. (2000). Assessment of the small-scale food processing subsector in Tanzania and Uganda: Study report (p. 65). The Technical Centre for Agricultural and Rural Cooperation CTA, Wageningen, Netherlands.

Dinh, H. T., Monga, C., Morisset, J., Kweka, J., Yagci, F., \& Yoshino, Y. (2013). Light manufacturing in Tanzania: A reform agenda for job creation and prosperity (p. 116). Washington DC 20001: The World Bank.

Dominic, T., \& Theuvsen, L. (2015). The impact of external and internal factors on strategic management practices of agribusiness firms in Tanzania. GlobalFood Discussion Papers No. 55. Retrieved from https://www.uni-goettingen.de/de/globalfood-discussion-paperseries/213486.html

Edelman, L. F., \& Brush, C. G. (2001). The mediating role of strategy on small firm performance. 2001 Academy of Management Research Conference (p. 50). Waltham, MA 02453.

Edelman, L. F., Brush, C. G., \& Manolova, T. (2005). Co-alignment in the resource-performance relationship: Strategy as mediator. Journal of Business Venturing, 20(3), 359-383.

Elly, T., \& Silayo, E. E. (2013). Agricultural information needs and sources of the rural farmers in Tanzania: A case of Iringa rural district. Library Review, 62(8), 547-566.

Fafchamps, M., \& Quinn, S. (2012). Results of sample survey in firms. In H. T. Dinh \& G. R. G. Clarke (Eds.), Performance of manufacturing firms in Africa: An empirical analysis (pp. 139-211). Washington, D.C: The World Bank.

Fornell, C., \& Larcker, D. F. (1981). Evaluating structural equation models with unobservable variables and measurement error. American Marketing Association, 18(1), 39-50.

Georgellis, Y., Joyce, P., \& Woods, A. (2000). Entrepreneurial action, innovation and business performance: The small independent business. Journal of Small Business and Enterprise Development, 7(1), 7-17. 
Chapter Three: Agribusiness Firm Resources and Performance: The Mediation Role of Strategic Management Practices

Gorman, P., \& Thomas, H. (1997). The theory and practice of competence-based competition. Long Range Planning, 30(4), 615-620.

Grant, R. M. (2013). Contemporary Strategy Analysis: Text and Cases (8th ed., p. 842). West Sussex, UK: John Wiley \& Sons, Inc.

Gresov, C., \& Drazin, R. (1997). Equifinality: Functional Equivalence in Organization Design. Academy of Management Review, 22(2), 403-428.

Hahn, C., Johnson, M. D., Herrmann, A., \& Huber, F. (2002). Capturing Customer Heterogeneity Using a Finite Mixture PLS Approach. Schmalenbach Business Review, 54(July), 243-269.

Hair, J. F., Black, W. C., Babin, B. J., \& Anderson, R. E. (2010). Multivariate Data Analysis (7th editio.). London: Prentince Hall.

Hair, J. F., Hult, G. T. M., Ringle, C. M., \& Sarstedt, M. (2014). A Primer on Partial Least Squares Structural Equation Modeling (PLS-SEM). Thousand Oaks, CA: Sage Publications, Inc.

Hatten, T. S. (2012). Small business management: Entrepreneurship and beyond (Fifth., p. 504). Mason, OH USA: South-Western Cengange Learning.

Hayes, A. F. (2012). Process: A versatile computational tool for observed variable mediation, moderation, and conditional process modeling. White Paper. Retrieved September 01, 2014, from http://www.afhayes.com/ public/process2012.pdf

Hitt, M. A., Bierman, L., Shimizu, K., \& Kochhar, R. (2001). Direct and moderating effects of human capital on strategy and performance in professional service firms: A resource-based perspective. Academy of Management Journal, 44(1), 13-28.

Hitt, M. A., Ireland, D. R., \& Hoskisson, R. E. (2009). Strategic management: Competitiveness and globalization: Concepts and cases (8th ed.). Mason, OH: South-Western Cengage Learning.

HODECT. (2010). Tanzania Horticultural Development Strategy 2012-2021. Horticultural Development Council of Tanzania. Dar es Salaam: Horticultural Development Council of Tanzania. Retrieved September 20, 2013, from http://hodect.org/pdf/National Horticulture Development Strategy.pdf

Hoskisson, R. E., Hoskisson, R. E., Hitt, M. A., Wan, W. P., \& Yiu, D. (1999). Theory and research in strategic management: Swings of a pendulum. Journal of Management, 25(3), 417-456.

Hough, J. R., \& White, M. a. (2004). Scanning actions and environmental dynamism. Management Decision, 42(6), 781-793.

Hulland, J. (1999). Use of Partial Least Squares (PLS) in strategic management research: A review of four recent studies. Strategic Management Journal, 20(2), 195-204.

IFAMR. (2014). African Agribusiness on the Move: Case Studies of Food and Agribusiness Success in Africa. (P. Goldsmith, M. Nkomo, M. Shelman, \& A. J. Connolly, Eds.)International Food and Agribusiness Management Review (Special Is., Vol. Special Is, p. 210). Washington DC 20005: IFAMA. 
Chapter Three: Agribusiness Firm Resources and Performance: The Mediation Role of Strategic Management Practices

Katera, L. (2009). The investment climate in Tanzania: Views of business executives. REPOA Brief, (December 17), 1-8.

Kinda, T., \& Loening, J. L. (2010). Small enterprise growth and the rural investment climate: Evidence from Tanzania. African Development Review, 22(1), 173-207.

Lieberman, M. B., \& Asaba, S. (2006). Why do firms imitate each other? Academy of Management Review, 31(2), 366-385.

Lwoga, E. T., Stilwell, C., \& Ngulube, P. (2011). Access and use of agricultural information and knowledge in Tanzania. Library Review, 60(5), 383-395.

Mahoney, J. T., \& McGahan, A. M. (2007). The field of strategic management within the evolving science of strategic organization. Strategic Organization, 5(1), 79-99.

McWilliams, A., Van Fleet, D. D., \& Wright, P. M. (2001). Strategic management of human resources for global competitive advantage. Journal of Business Strategies, 18(1).

Mikkola, M. (2008). Coordinative structures and development of food supply chains. British Food Journal, 110(2), 189-205.

Ministry of Industry and Trade - MOIT. (2011). Integrated industrial development strategy 2025. United Republic of Tanzania. Retrieved September 10, 2014, from http://www.trademarksa.org/sites/default/files/publications/Integrated Ind Dev Strategy_Main_Report.pdf

Mugera, A. W. (2012). Sustained competitive advantage in agribusiness: Applying the resourcebased theory to human resources. International Food and Agribusiness Management Review, 15(4), 27-48.

NBS. (2012). Integrated Business Survey, 2010 Tanzania Mainland Distributive Trade Analytical Report. National Bureau of Statistics/ Ministry of Finance Tanzania. Retrieved September 22, 2013, from

http://www.nbs.go.tz/nbs/index.php?option=com_content\&view=article\&id=375:integrated -business-survey-2010-distributive-trade-analytical-report\&catid=82:intergrated-businesssurvey \&Itemid $=147$

Nichter, S., \& Goldmark, L. (2009). Small firm growth in developing countries. World Development, 37(9), 1453-1464. Retrieved from http://linkinghub.elsevier.com/retrieve/pii/S0305750X09000928

Nunnally, J. C. (1978). Psychometric theory. New York: McGraw-Hill.

Pansiri, J., \& Temtime, Z. T. (2008). Assessing managerial skills in SMEs for capacity building. Journal of Management Development, 27(2), 251-260.

Penrose, E. T. (1959). The Theory of the Growth of the Firm. Oxford: Basil Blackwell.

Penrose, E. T. (2009). The theory of the growth of the firm: With a new introduction by Christos N. Pitelis (Fourth., p. 249). Oxford: Oxford University Press.

Peterson, R. A., \& Kim, Y. (2013). On the relationship between coefficient alpha and composite reliability. The Journal of Applied Psychology, 98(1), 194 - 198. 
Chapter Three: Agribusiness Firm Resources and Performance: The Mediation Role of Strategic Management Practices

Porter, M. E. (1985). Competitive advantage: Creating and sustaining superior performance. New York: Free press.

Prahalad, C. K., \& Hamel, G. (1990). The Core Competence of the Corporation. Harvard Business Review, 68(3), 79-91.

Preacher, K. J., \& Hayes, A. F. (2008). Asymptotic and resampling strategies for assessing and comparing indirect effects in multiple mediator models. Behavior Research Methods, 40(3), 879-891.

Remaud, H., \& Courdec, J.-P. (2006). Wine business practices: A new versus old wine world perspective. Agribusiness, 22(3), 405-416.

Ringle, C. M., Sarstedt, M., \& Mooi, E. A. (2010). Response-based segmentation using finite mixture partial least squares: Theoretical foundations and an application to american customer satisfaction index data. In R. Stahlbock, S. F. Crone, \& S. Lessmann (Eds.), Data Mining: Annals of Information Systems (Vol. 8, pp. 19-49). Boston, MA: Springer US.

Ringle, C. M., Sarstedt, M., \& Straub, D. W. (2012). Editor's comments: A critical look at the use of PLS-SEM. MIS Quarterly, 36(1).

Ringle, C. M., Wende, S., \& Will, A. (2005). SmartPLS 2. Hamburg: SmartPLS. Retrieved from http://www.smartpls.com

Robert, M. J., Shepherd, D. A., \& Sharfman, M. P. (2011). Erratic strategic decisions: When and why managers are inconsistent in strategic decision making. Strategic Management Journal, 32(7), 683-704.

Rudd, J. M., Greenley, G. E., Beatson, A. T., \& Lings, I. N. (2008). Strategic planning and performance: Extending the debate. Journal of Business Research, 61(2), 99-108.

Sanchez, R. (2004). Understanding competence-based management: Identifying and managing five modes of competence. Journal of Business Research, 57(5), 518-532. Retrieved from http://www.sciencedirect.com/science/article/pii/S0148296302003181

Sarstedt, M., Becker, J.-M., Ringle, C. M., \& Schwaiger, M. (2011). Uncovering and treating unobserved heterogeneity with FIMIX-PLS: Which model selection criterion provides an appropriate number of segments? Schmalenbach Business Review, 63(January), 34-62.

Shrout, P. E., \& Bolger, N. (2002). Mediation in experimental and nonexperimental studies: New procedures and recommendations. Psychological Methods, 7(4), 422-445.

Simon, H. A. (1957). Models of man: Social and rational (p. 279). New York: John Wiley \& Sons, Inc.

Sinha, K. K., \& Van de Ven, A. H. (2005). Designing work within and between organizations. Organization Science, 16(4), 389-408.

Siyao, P. O. (2012). Barriers in accessing agricultural information in Tanzania with a gender perspective: The case study of small-scale sugar cane growers in Kilombero district. The Electronic Journal on Information Systems in Developing Countries, 51(6), 1-19.

Stacey, R. D. (2011). Strategic management and organisational dynamics: The challenge of complexity (6th ed.). Upper Saddle River, NJ: Pearson Prentice Hall/Financial Times Press. 
Chapter Three: Agribusiness Firm Resources and Performance: The Mediation Role of Strategic Management Practices

Teece, D. J. (2007). Explicating dynamic capabilities: The nature and microfoundations of (sustainable) enterprise performance. Strategic Management Journal, 28(13), 1319-1350.

Theuvsen, L., Heyder, M., \& Niederhut-Bollmann, C. (2010). Does strategic group membership affect firm performance? An analysis of the German brewing industry. German Journal of Agricultural Economics, 59(1), 61-76.

Wernerfelt, B. (1984). A resource-based view of the firm. Strategic Management Journal, 5(2), 171-180.

Wheelen, T. L., \& Hunger, J. D. (2006). Strategic management and business policy. Upper Saddle River, NJ: Pearson Education, Inc.

Woods, A., \& Joyce, P. (2003). Owner-managers and the practice of strategic management. International Small Business Journal, 21(2), 181-195.

World Bank. (2012). Performance of manufacturing firms in Africa: An empirical analysis. (H. T. Dinh \& G. R. G. Clarke, Eds.) (Directions., p. 211). Washington DC 20433: International Bank for Reconstruction and Development / The World Bank.

Wright, P. M., Dunford, B. B., \& Snell, S. A. (2001). Human resources and the resource based view of the firm. Journal of Management, 27, 701-721.

Wright, P. M., \& McMahan, G. C. (2011). Exploring human capital: putting human back into strategic human resource management. Human Resource Management Journal, 21(2), 93 104 


\section{Appendix 3-1: Descriptive Statistics of Variable Items}

\begin{tabular}{|c|c|c|c|}
\hline Item & Statement/Question & Mean & $\begin{array}{l}\text { Std. } \\
\text { Dev }\end{array}$ \\
\hline \multicolumn{4}{|c|}{ Level of expertise of the manager $(\mathrm{EXP})$ scale from $1=$ strongly disagree to $5=$ strongly agree } \\
\hline EXP_1 & Level of expertise in Bookkeeping and Accounting & 3.03 & 1.094 \\
\hline EXP_2 & Level of expertise in Managing employees & 3.45 & 1.053 \\
\hline EXP_3 & Level of expertise in Marketing techniques & 3.26 & 1.056 \\
\hline EXP_4 & Level of expertise in Financial management & 3.21 & 1.107 \\
\hline EXP_5 & Level of expertise in Stock taking \& Record keeping & 3.36 & 1.081 \\
\hline EXP_6 & Level of expertise in Food quality \& Safety standards & 3.56 & 1.056 \\
\hline EXP_7 & Level of expertise in Customer care & 3.72 & 1.006 \\
\hline EXP_8 & Level of expertise in product presentation & 3.37 & 1.074 \\
\hline EXP_9 & Level of expertise in food processing & 3.73 & 1.070 \\
\hline \multicolumn{4}{|c|}{ Information access to the firm (INFO) } \\
\hline \multicolumn{2}{|c|}{$\begin{array}{l}\text { Scale: } 1=\text { Completely inaccessible } 2=\text { Inaccessible, } 3=\text { Average access, } 4=\text { Accessible } \\
\text { accessible }\end{array}$} & \multicolumn{2}{|c|}{ and 5=Highly } \\
\hline INFO_1 & Information on where to get raw materials & 4.34 & 0.941 \\
\hline INFO_2 & Information access on changes in product prices & 4.04 & 1.049 \\
\hline INFO_3 & Information access on where to sell & 3.97 & 0.993 \\
\hline INFO_4 & Information access concerning customers' whereabouts & 3.89 & 1.014 \\
\hline INFO_5 & Information access about when to sell & 3.92 & 1.013 \\
\hline INFO_6 & Information access on competitors & 3.70 & 1.128 \\
\hline INFO_7 & Information access on tax rates & 3.38 & 1.286 \\
\hline INFO_8 & Information access on trade associations & 3.61 & 1.177 \\
\hline
\end{tabular}

Strategic Management Practices (STM) practices (scale from $1=$ Strongly disagree to $5=$ Strongly agree)

\begin{tabular}{llll}
\hline STM_A & Environmental scanning activities (3 items) & 3.48 & 1.196 \\
STM_B & Strategy planning activities (4 items) & 3.28 & 1.195 \\
STM_C & Strategic implementation activities (7 items) & 3.19 & 1.195 \\
STM_D & Evaluation and control activities (3 items) & 3.31 & 1.254
\end{tabular}

Performance (PERF) 1=Decrease 2=A little decrease 3=Stay the same 4=A little increase 5=Increase

\begin{tabular}{llll}
\hline REV_1a & Sales revenue this year in 2013 & 3.73 & 1.082 \\
REV_1b & Sales revenue last year in 2012 & 3.60 & 0.971 \\
REV_1c & Sales revenue in 2011 & 3.50 & 0.991 \\
Cost_2a & Total expenses this year in 2013 & 3.95 & 0.928 \\
Cost_2b & Total expenses last year in 2012 & 3.73 & 0.841 \\
Cost_2c & Total expenses in 2011 & 3.64 & 0.873 \\
Emp_3a & Number of employees this year in 2013 & 3.21 & 0.896 \\
Emp_3b & Number of employees last year in 2012 & 3.08 & 0.662 \\
Emp_3c & Number of employees in 2011 & 3.09 & 0.623
\end{tabular}


Chapter Three: Agribusiness Firm Resources and Performance: The Mediation Role of Strategic Management Practices

\section{Appendix 3-2: Cross Loading}

\begin{tabular}{lcllc}
\hline & EXP & INFO & PERF & STM \\
\hline EXP_1 & $\mathbf{0 . 7 4 9}$ & 0.453 & 0.179 & 0.375 \\
EXP_2 & $\mathbf{0 . 8 3 3}$ & 0.344 & 0.323 & 0.445 \\
EXP_3 & $\mathbf{0 . 8 4 6}$ & 0.397 & 0.351 & 0.463 \\
EXP_6 & $\mathbf{0 . 7 8 7}$ & 0.362 & 0.286 & 0.453 \\
EXP_8 & $\mathbf{0 . 7 8 6}$ & 0.424 & 0.381 & 0.415 \\
\hline INFO_2 & 0.35 & $\mathbf{0 . 6 5 5}$ & 0.257 & 0.316 \\
INFO_4 & 0.325 & $\mathbf{0 . 8 0 0}$ & 0.261 & 0.333 \\
INFO_5 & 0.381 & $\mathbf{0 . 7 9 4}$ & 0.293 & 0.361 \\
INFO_6 & 0.34 & $\mathbf{0 . 6 6 5}$ & 0.282 & 0.329 \\
INFO_7 & 0.334 & $\mathbf{0 . 5 8 8}$ & 0.227 & 0.337 \\
\hline REV_1a & 0.251 & 0.337 & $\mathbf{0 . 7 7 0}$ & 0.476 \\
REV_1b & 0.374 & 0.338 & $\mathbf{0 . 8 7 5}$ & 0.503 \\
REV_1c & 0.322 & 0.253 & $\mathbf{0 . 8 2 6}$ & 0.456 \\
\hline STM_A & 0.510 & 0.397 & 0.544 & $\mathbf{0 . 9 2 6}$ \\
STM_B & 0.472 & 0.441 & 0.537 & $\mathbf{0 . 9 3 0}$ \\
STM_C & 0.515 & 0.474 & 0.544 & $\mathbf{0 . 9 3 3}$ \\
STM_D & 0.506 & 0.467 & 0.540 & $\mathbf{0 . 9 3 6}$ \\
\hline
\end{tabular}

\section{Appendix 3-3: Collinearity Assessment}

\begin{tabular}{|l|ll|}
\hline Linear regression Model 1: & Linear regression Model 2: & \\
Independent variables & Independent variables & \\
EXP (1.322) INFO (1.322) & EXP (1.567) INFO (1.442) & STM (1.535) \\
$($ Dependent variable STM) & (Dependent variable PERF) & \\
\hline
\end{tabular}

Note:

VIF values in Parentheses. VIF is a metric for multicollinearity

Multicollinearity among predictor variables represents and important concern in assessing path model, since it can inflate bootstrap standard errors and therefore trigger type II errors

Appendix 3-4: Effect Sizes ( $f^{2}$ and $q^{2}$ Values)

\begin{tabular}{lcccccc}
\hline & \multicolumn{3}{c}{ STM } & \multicolumn{3}{c}{ PERFORMANCE } \\
\cline { 2 - 7 } & $\begin{array}{c}\text { Path } \\
\text { Coefficient }\end{array}$ & $\begin{array}{c}\boldsymbol{f}^{2} \text { effect } \\
\text { size }\end{array}$ & $\begin{array}{c}\boldsymbol{q}^{2} \text { effect } \\
\text { size }\end{array}$ & $\begin{array}{c}\text { Path } \\
\text { Coefficient }\end{array}$ & $\begin{array}{c}\boldsymbol{f}^{2} \text { effect } \\
\text { size }\end{array}$ & $\begin{array}{c}\boldsymbol{q}^{2} \text { effect } \\
\text { size }\end{array}$ \\
\hline $\mathrm{EXP} \rightarrow \mathrm{STM}$ & 0.399 & $0.156 \mathrm{~L}$ & $0.1304 \mathrm{~S}$ & & & \\
$\mathrm{INFO} \rightarrow$ STM & 0.281 & $0.082 \mathrm{~S}$ & $0.1217 \mathrm{~S}$ & & & \\
$\mathrm{EXP} \rightarrow$ PERF & & & & 0.064 & $0.003 \mathrm{~S}$ & $0.0018 \mathrm{~S}$ \\
$\mathrm{INFO} \rightarrow$ PERF & & & & 0.109 & $1.012 \mathrm{~S}$ & $0.0083 \mathrm{~S}$ \\
$\mathrm{STM} \rightarrow$ PERF & & & & 0.495 & $0.196 \mathrm{M}$ & $0.1228 \mathrm{~S}$ \\
\hline
\end{tabular}

Note: $f^{2}$ is a measure of the impact of a specific predictor construct on an endogenous construct. $q^{2}$ As a relative measure of predictive relevance. The values of $\mathbf{0 . 0 2 , 0 . 1 5}$ and $\mathbf{0 . 3 5}$ indicate that an exogenous latent variable has a small (S), medium (M) and large (L) effect respectively. 
Chapter Three: Agribusiness Firm Resources and Performance: The Mediation Role of Strategic Management Practices

Appendix 3-5: Validity and Reliability Measures (Multigroup analysis)

\begin{tabular}{llrrrr}
\hline Measure & $\begin{array}{c}\text { Aggregate } \\
\text { (Full Sample) }\end{array}$ & $\mathbf{n = 1}$ & $\mathbf{n = 2}$ & $\mathbf{n = 3}$ \\
\hline Convergent validity & AVE(EXP) & 0.642 & 0.694 & 0.670 & 0.614 \\
measure & AVE (INFO) & 0.497 & 0.517 & 0.737 & 0.507 \\
& AVE (STM) & 0.867 & 0.664 & 0.879 & 0.902 \\
& AVE (PERF) & 0.680 & 0.808 & 0.565 & 0.610 \\
\hline Internal consistency & CR (EXP) & 0.899 & 0.919 & 0.910 & 0.888 \\
reliability measure & CR (INFO) & 0.830 & 0.841 & 0.933 & 0.835 \\
& CR (STM) & 0.963 & 0.887 & 0.967 & 0.974 \\
& CR (PERF) & 0.864 & 0.926 & 0.794 & 0.823 \\
\hline Discriminant validity & E EXP & 0.801 & 0.833 & 0.819 & 0.784 \\
measure & E INFO & 0.705 & 0.719 & 0.858 & 0.712 \\
& E STM & 0.825 & 0.815 & 0.938 & 0.950 \\
& \& PERF & 0.925 & 0.899 & 0.752 & 0.781 \\
\hline & $\mathrm{N}$ & 229 & & & \\
\cline { 2 - 6 } & $\mathrm{n}$ & & 50 & 50 & 129
\end{tabular}

CR, Composite reliability $\varepsilon$, measure for criterion by Fornell and Larcker (Fornell \& Larcker, 1981),

$\mathrm{n}$ size of segment, $\mathrm{N}$ size of full sample

\section{Appendix 3-6: PLS Model Multigroup Analysis}

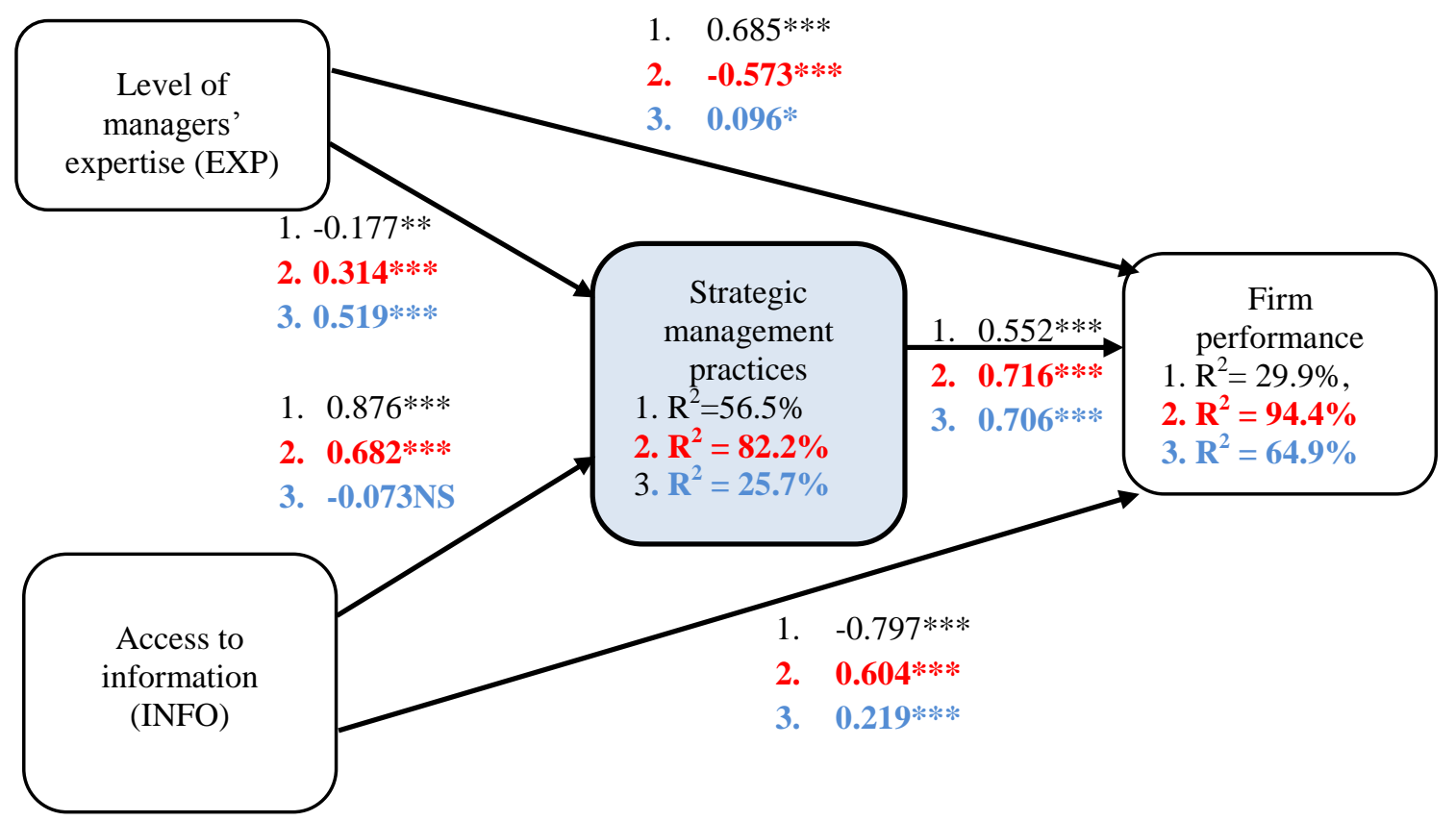


Chapter Three: Agribusiness Firm Resources and Performance: The Mediation Role of Strategic Management Practices

Appendix 3-7: Three-Segments PLS Analysis (Differences between Path Relationships)

\begin{tabular}{|c|c|c|c|c|c|c|}
\hline & $\begin{array}{l}\text { Segment 1: } \\
\quad \mathrm{N}=50\end{array}$ & $\begin{array}{l}\text { Segment 2: } \\
\quad \mathrm{N}=50\end{array}$ & $\begin{array}{c}\text { Segment } 3 \\
\mathrm{~N}=129\end{array}$ & $\begin{array}{c}\text { Segment } 1 \\
\text { Vs } \\
\text { Segment } 2\end{array}$ & $\begin{array}{c}\text { Segment } 1 \\
\text { Vs } \\
\text { Segment } 3\end{array}$ & $\begin{array}{c}\text { Segment } 2 \\
\text { Vs } \\
\text { Segment } 3\end{array}$ \\
\hline & \multicolumn{3}{|c|}{ path coefficient (std errors) } & \multicolumn{3}{|c|}{ path coefficients (t values) } \\
\hline & $\mathrm{p}^{(1)}$ & $\mathrm{p}^{(2)}$ & $\mathrm{p}^{(3)}$ & $\left|p^{(1)}-p^{(2)}\right|$ & $\left|p^{(1)}-p^{(3)}\right|$ & $\left|p^{(2)}-p^{(3)}\right|$ \\
\hline $\mathrm{EXP} \rightarrow \mathrm{PERF}$ & $\begin{array}{c}0.685 * * * \\
(0.090)\end{array}$ & $\begin{array}{c}-0.573 * * * \\
(0.077)\end{array}$ & $\begin{array}{l}0.096^{*} \\
(0.074)\end{array}$ & $\begin{array}{l}1.258 * * * \\
(10.729)\end{array}$ & $\begin{array}{c}0.589 * * * \\
(5.094)\end{array}$ & $\begin{array}{c}0.669 * * * \\
(6.309)\end{array}$ \\
\hline $\mathrm{EXP} \rightarrow \mathrm{STM}$ & $\begin{array}{c}-0.177 * * \\
(0.082)\end{array}$ & $\begin{array}{c}0.314 * * * \\
(0.082)\end{array}$ & $\begin{array}{c}0.519 * * * \\
(0.081)\end{array}$ & $\begin{array}{c}0.49 * * * \\
(4.277)\end{array}$ & $\begin{array}{c}0.696^{* * *} \\
(6.081)\end{array}$ & $\begin{array}{c}0.205^{* * *} \\
(3.364)\end{array}$ \\
\hline $\mathrm{INFO} \rightarrow \mathrm{PERF}$ & $\begin{array}{c}-0.797 * * * \\
(0.152)\end{array}$ & $\begin{array}{c}0.604 * * * \\
(0.103)\end{array}$ & $\begin{array}{c}0.219 * * * \\
(0.089)\end{array}$ & $\begin{array}{c}1.401 * * * \\
(7.708)\end{array}$ & $\begin{array}{c}1.016^{* * * *} \\
(5.433)\end{array}$ & $\begin{array}{c}0.385^{* * *} * \\
(2.849)\end{array}$ \\
\hline $\mathrm{INFO} \rightarrow \mathrm{STM}$ & $\begin{array}{c}0.876 * * * \\
(0.072)\end{array}$ & $\begin{array}{c}0.682 * * * \\
(0.077)\end{array}$ & $\begin{array}{l}-0.073 \\
(0.092)\end{array}$ & $\begin{array}{l}0.194^{*} \\
(1.859)\end{array}$ & $\begin{array}{c}0.949 \\
(8.206)\end{array}$ & $\begin{array}{c}0.755^{* * * *} \\
(6.334)\end{array}$ \\
\hline $\mathrm{STM} \rightarrow \mathrm{PERF}$ & $\begin{array}{c}0.552 * * * \\
(0.140)\end{array}$ & $\begin{array}{c}0.716 * * * \\
(0.146)\end{array}$ & $\begin{array}{c}0.706^{* * * *} \\
(0.059)\end{array}$ & $\begin{array}{c}0.614 \\
(0.819)\end{array}$ & $\begin{array}{c}0.154 \\
(1.023)\end{array}$ & $\begin{array}{c}0.010 \\
(0.064)\end{array}$ \\
\hline
\end{tabular}

Note: $\mathrm{p}^{(1)}, \mathrm{p}^{(2)}$ and $\mathrm{p}^{(3)}$ are path coefficients for segment 1,2 and 3 respectively Significance at $* * * \mathrm{p}<0.01 ; * * \mathrm{p}<0.05$ and $* \mathrm{p}<0.1$

\section{Appendix 3-8: Characteristics of the Three Segments}

\begin{tabular}{|c|c|c|c|c|c|c|}
\hline \multirow[b]{2}{*}{ Variable } & $\begin{array}{c}\text { Segment } \\
1\end{array}$ & $\begin{array}{c}\text { Segment } \\
2 \\
\end{array}$ & $\begin{array}{c}\text { Segment } \\
3 \\
\end{array}$ & $\begin{array}{c}\text { Full } \\
\text { sample }\end{array}$ & \multirow{2}{*}{$\begin{array}{c}\text { F } \\
\text { score }\end{array}$} & \multirow{2}{*}{$\begin{array}{l}\text { sig. } \\
\text { differ } \\
\text { ence }\end{array}$} \\
\hline & \multicolumn{4}{|c|}{ Mean (std. dev.) } & & \\
\hline $\begin{array}{l}\text { Gender of firm manager } \\
\text { Male }\end{array}$ & $\begin{array}{c}0.42 \\
(0.499)\end{array}$ & $\begin{array}{c}0.34 \\
(0.479)\end{array}$ & $\begin{array}{c}0.40 \\
(0.491)\end{array}$ & $\begin{array}{c}0.39 \\
(0.489)\end{array}$ & 0.361 & \\
\hline Female & $\begin{array}{c}0.58 \\
(0.499)\end{array}$ & $\begin{array}{c}0.66 \\
(0.479)\end{array}$ & $\begin{array}{c}0.60 \\
(0.491)\end{array}$ & $\begin{array}{c}0.61 \\
(0.489)\end{array}$ & 0.361 & \\
\hline Age of the manager (years) & $\begin{array}{c}41.91 \\
(10.84)\end{array}$ & $\begin{array}{c}44.33 \\
(9.942)\end{array}$ & $\begin{array}{c}42.4 \\
(10.943)\end{array}$ & $\begin{array}{c}42.72 \\
(10.97)\end{array}$ & 0.74 & \\
\hline Age of the firm (yrs.) & $\begin{array}{l}9.75^{1} \\
(6.44)\end{array}$ & $\begin{array}{c}6.96 \\
(4.02)\end{array}$ & $\begin{array}{l}6.89^{3} \\
(4.53)\end{array}$ & $\begin{array}{c}7.54 \\
(5.04)\end{array}$ & 6.478 & $* * *$ \\
\hline $\begin{array}{l}\text { Years of working experience } \\
\text { in the firm (yrs.) }\end{array}$ & $\begin{array}{l}9.07^{1} \\
(6.40)\end{array}$ & $\begin{array}{c}6.54 \\
(3.79)\end{array}$ & $\begin{array}{l}6.12^{3} \\
(4.39)\end{array}$ & $\begin{array}{c}6.86 \\
(4.91)\end{array}$ & 6.87 & $* * *$ \\
\hline $\begin{array}{l}\text { Education } \\
\text { Secondary schooling }\end{array}$ & $\begin{array}{c}0.44 \\
(0.501)\end{array}$ & $\begin{array}{c}0.42 \\
(0.499)\end{array}$ & $\begin{array}{c}0.40 \\
(0.491)\end{array}$ & $\begin{array}{c}0.41 \\
(0.493)\end{array}$ & 0.159 & \\
\hline College certificate & $\begin{array}{c}0.20 \\
(0.404)\end{array}$ & $\begin{array}{c}0.16 \\
(0.370)\end{array}$ & $\begin{array}{c}0.16 \\
(0.363)\end{array}$ & $\begin{array}{c}0.17 \\
(0.373)\end{array}$ & 0.268 & \\
\hline University & $\begin{array}{c}0.08 \\
(0.274)\end{array}$ & $\begin{array}{c}0.14 \\
(0.351)\end{array}$ & $\begin{array}{c}0.11 \\
(0.312)\end{array}$ & $\begin{array}{c}0.11 \\
(0.313)\end{array}$ & 0.459 & \\
\hline $\begin{array}{l}\text { Asset management } \\
\text { familiar you yith } \\
\text { sheet'?) }\end{array}$ & $\begin{array}{c}0.74 \\
(0.443)\end{array}$ & $\begin{array}{l}0.84^{2} \\
(0.37)\end{array}$ & $\begin{array}{c}0.61^{3} \\
(0.489)\end{array}$ & $\begin{array}{c}0.69 \\
(0.464)\end{array}$ & 4.877 & $* * *$ \\
\hline $\begin{array}{l}\text { Uses at least } 5 \text { other STM } \\
\text { tools }{ }^{\mathrm{d}}\end{array}$ & $\begin{array}{l}0.80^{1} \\
(0.4)\end{array}$ & $\begin{array}{c}0.64 \\
(0.48) \\
\end{array}$ & $\begin{array}{c}0.63^{3} \\
(0.48) \\
\end{array}$ & $\begin{array}{c}0.66 \\
(0.47) \\
\end{array}$ & 2.543 & $*$ \\
\hline
\end{tabular}

Note: Superscript numbers 1, 2 and 3 indicate significant different groups based on Scheffe's test where the latter represents a set of group differences. d; other tools listed are profit and loss statement, cash flow, sales trend, cost benefit ratio analysis, performance appraisal, risk analysis, net present values, brainstorming, and SWOT analysis. 


\title{
Chapter Four
}

\section{HomeVeg Tanzania Managing a New Strategy amidst GLIMPSE Challenges (Case Study)}

Theresia Dominic, Ludwig Theuvsen, Mussa Mvungi and Ray Ufunguo

\begin{abstract}
HomeVeg Tanzania Ltd. is a fresh fruits and vegetables export company in Arusha, Tanzania. Since its inception, five years ago, they have recruited 55 employees, working with 1,600 smallholder farmers. They successfully produce high quality products - up to seven tons per week that meet GLOBALG.A.P. and British Retail Consortium standards. Although sales are rising, production rates are affected by an increasing amount of reject due to product handling and strict export standards. Its next strategy is to add outlets in the domestic market. This case discusses its journey towards accomplishing the opportunity, despite obstacles under the acronym GLIMPSE.
\end{abstract}

This paper was published in a similar version in the International Food and Agribusiness Management Review (IFAMR), 2014, vol. 17, issue B. 


\subsection{Introduction}

HomeVeg exports vegetables from Tanzania to Europe. Since its inception in 2009, it has become the leading vegetable exporter in the country with a capacity of 7 tons per week. The company processes high value vegetables by working directly with groups of smallholder farmers with average plot size of 0.2 hectares. As the company grows, success is attributed to its close link with farmers. It has recruited 1,600 farmers who are fully trained to grow products that meet international export standards. Its core activities include capacity building, marketing and finance with a team of 55 employees (15 permanent and 40 temporary). As the success in delivering high value products increases, a challenge in dealing with unsold produce (rejects) increases as well. Several alternative solutions are given, however the optimum decision is yet to be achieved.

\subsection{Company Background}

Located in Arusha, HomeVeg is a private limited company co-founded by Mussa Mvungi and Machel Tarimo, two young Tanzanian graduates, with sufficient experience in horticulture and international trade. In five years they were able to grow the company by exporting high quality fine beans, peas, chilies and baby corn. From the beginning, they worked closely with a the Center for Sustainable Development Initiative (CSDI); to secure a grant to cover the costs of renting a pack house, cold truck, collection truck and training programs on vegetable processing and international trade. With a mission of promoting the production and marketing of fresh horticultural products, the company was able to supply the UK, Belgium, Germany and the Netherlands - and is searching for more buyers.

HomeVeg quickly gained momentum in 2011 when the number of farmers increased from 1,000 (in year 2009) to 1,200 (2011) and currently 1,600 (2013). The farmers are located in northern and eastern part of the country including collection centers in Arumeru, Simanjiro, Moshi and Lushoto districts in Arusha, Manyara, Kilimanjaro and Tanga regions respectively. HomeVeg's has a formal contract with the farmers and regularly supervises activities such as fertilization, spraying, crop husbandry, harvesting and pre-grading. The farmers are divided into eight groups who receive training in six major areas: safe use of pesticides; good agriculture practice (G.A.P.); 
farmers' accountability; cluster management training; and association management training.

Products flow from farms to international wholesale buyers, where HomeVeg collects produce at the farm gate and transports it to its packing house in Arusha, where the product is graded and packaged. The load is then processed for transport and sent to the buyers; Special fruit (Belgium), Fresh to Go (UK), Bud Holland and Nature's Pride. Agents involved in processing and handling the freight include TahaFresh Handling Ltd. (Tanzania) and Kuehne and Nagel Company (International). In the process of capturing the market in Europe, the company strategically facilitated the GLOBALG.A.P and the British Retail Consortium (BRC) certification for the farmers. In 2011, three out of eight groups were certified and the number has increased to seven in 2013.

\subsubsection{Current Management Structure}

Employees are divided into three teams and departments: capacity building and production; marketing; and finance/administration. The top management is comprised of the founding members. Mr. Mvungi is the Managing and Marketing Director. Mr. Tarimo is the Director of Finance and Mr. Mziray is the Director of Production. Middle management level is comprised of unit managers, and lower level employees include secretaries, clerks, storekeepers and production supervisors. The company has a total of 15 permanent and 40 temporary employees.

Mvungi is responsible for establishing the export forecast based on market conditions. He directs the collection of produce, grading, packaging, exporting and market information search. Based upon the current sales capacity of 7 tons per week, he has to accomplish an objective of 20 tons per week of produce by the year 2015 and to increase annual profit from $\$ 15,257$ to $\$ 127,593$ USD by year 2016 . Tarimo directs the financing, administrative and people management, while enforcing HomeVeg core values: Quality, Safety, Reliability and Transparency. Mziray is responsible for developing small scale farmers by providing regular training, contracting and supervision. Major objective is to recruit at least 3,500 farmers and up to 200 hectares of farms by year 2016 . 


\subsubsection{Key Success Factors}

Having regular contact with farmers, close control of the supply chain, expertise in quality management system, provision of regular training to farmers, are the HomeVeg key success factors. Also, relationship based on trust was the key between the company and key actors within the chain. For example, HomeVeg has honored past agreement with farmers and process their payments on timely basis because it is at its best interest to build trustworthy and long relationship with the farmers. Hence in future transactions, the farmers have put trust that they will not be exploited.

The demand for fresh produce has increased because over the last decade Europe has recorded a trade deficit in fresh and processed fruits and vegetables, totaling €9.8 billion in 2011 and imports have picked up quite considerably as well (MAP, 2012). In this case there has been a growth in land committed by farmers from 0.3 to 0.94 ha. of harvest per week after introducing a planting program in 2011. The program runs successfully because HomeVeg has invested input resources to the business arrangement and on the other hand the farmers are connected to export markets, get access to technical services and free training sessions.

\subsection{Strategic Issues for HomeVeg}

Fresh vegetable sector in Tanzania continues to grow with competitors like Serengeti fresh, Tanhort, Arusha bloom, etc. Therefore the challenge for HomeVeg is how to maintain their position as the leading exporter. As they work on seeking more buyers in Europe, they have announced plans to increase number of farmers in order to satisfy the market demand, install a better quality management system in the pack house for speed efficiency in processing, and negotiate with Government and development agencies in installing cold rooms near farm gates. Furthermore, HomeVeg has not only built its own new pack house but also found a strategic location for transport that is spacious.

The management sees a potential on vegetable and fruit cultivation in Tanzania therefore they focus on providing regular training to comply with international standards. As a result, amount of farm produce collection has successfully increased in terms of weight and variety. In addition to that sales volume has escalated from 115.4 tons in year 2010 to 221.2 tons in year 2012 but the sales could have been higher if it wasn't for the 
high amount of rejects. The rejects are unsold produce, caused by natural differences in size, shape and color; and breakage during washing and transportation; but fit for consumption.

Alternative strategies are arranged to design a marketing entry strategy for a domestic market. However, if HomeVeg establishes a formal domestic market, some problems will arise such as; supplying substandard quality of produce which might jeopardize the HomeVeg's image, inability to forecast amount of unsold products and rejects, hence making impossible to enforce a contractual agreement with local buyers.

Furthermore, there is a pricing issue whereby, their price might be higher than their competitors in domestic markets. Until late November 2013, the directors are struggling with the pricing, promotion and product decisions for the domestic market. However, as they move forward in creating a strategic market entry to the domestic market, the firm encounters additional challenges in following areas: Government, losses and wastage, infrastructure, markets, politics and policies, science and innovation; and environment.

\section{Government}

Costs of landing, handling and aviation fuel are higher at Kilimanjaro International airport than other airports in East Africa, hence indirectly affects HomeVeg's trading charges. Considering that, Tanzania ranks 139 out of 189 countries in the criteria of 'ability to trade across borders' (World Bank, 2013), the Government should assess the source of this problem to resolve high charges and unnecessary port delays. A better solution might reduce freight operational charges and increase HomeVeg revenue by $9.5 \%$.

\section{Losses and Wastage}

A post-harvest loss from the pack house is between 20 to 40 percent. Several efforts have been tried to manage losses along the food chain, but it all comes down to more funding requirements. There's an opportunity to install cold-room facility near farm areas where vegetables and other variety of produces can be stored soon after harvesting.

\section{Infrastructure}

It is unfortunate that roads, power supply, and air/sea ports are in poor condition due to the major economy transformation and expansion process in the country. HomeVeg has to find alternatives. For example, installing standby generators during 
periods of power outages and regular financing of auto spares for truck maintenance due to poor road conditions. After British airways pulled its services in 2013, HomeVeg is seeking direct flight services to the UK where their major buyers are located.

\section{Markets}

Changes in population structure, customer preferences, and income levels are few of the factors that increase the demand of vegetables all over the world; however the opportunity to grasp more market share, outweighs HomeVeg ability to supply. A program is already set to recruit more farmers, so the challenging part is making decisions on pricing, promotion, product and designing a marketing strategy for domestic market (as discussed earlier).

\section{Politics and Policies}

HomeVeg is working on negotiating export subsidies such as tax relief for exporters and getting a rebate on imported manufacturing machines. The outcome will increase competitiveness with other exporters globally.

\section{Science and Innovation}

Generally, teamwork between scientists, researchers, farmers and food processors is limited where one part accuses the other of not delivering results that are applicable to the Tanzanian environment. HomeVeg is confronted with lack of up-to-date information on seedling technology, fertilizer, better farming practices and agricultural marketing database. The latter is much needed for developing a plan for domestic market.

\section{Environment}

There is a crisis of water pollution while trying to comply with the standards. In this case they have included sensitization program to educate the public on safe discharge of waste. However as it becomes too costly to the company, public-private partnership intervention is encouraged.

\subsection{Looking Ahead}

Considering the challenges, it seems that recruiting more farmers and increasing export capacity alone will not solve supply gaps and post - harvest losses. The next step is to engage in public-private partnership programs, communicate policy shortfalls with 
real evidences and get the government to commit to support horticulture industry. The business by itself has a great opportunity to grow internationally as well as in the domestic markets due to increasing demand of fresh vegetables. Since the company values quality (as a key success factor), the biggest challenge is how to manage unsold product (rejects). The idea of disposing the remaining produce into the domestic market should not be the ultimate solution. Much has to be done in the area of quality control if the company wants to expand the market. 


\section{References}

Connolly, A. J., \& Phillips-Connolly, K. 2012. Can Agribusiness Feed 3 Billion New People and Save the Planet? A GLIMPSE into the Future. International Food and Agribusiness Management Review 15 (Special Issue B): 139-152.

MAP 2012. 'Monitoring Agri-Trade Policy: The EU and Major World Players in Fruit and Vegetable Trade' European Commission, http://ec.europa.eu/agriculture/tradeanalysis/map/index_en.htm

World Bank. 2013. From Privilege to Competition: Unlocking Private-Led Growth in the Middle East and North Africa. Washington, DC: World Bank 


\section{Chapter Five}

\section{Summary, Conclusions and Implications}

\subsection{Summary and Conclusions}

This study offers explanations on the effects of firm attributes, internal resources and external environmental factors on the application of strategic management practices. The effects are further explained through statistical hypothesis testing using a structural model analysis. Based on the results from the model analysis several recommendations are made in order to encourage managers to focus on critical factors and take effective managerial actions. Furthermore, the role of strategic management practices in connecting firm resources to firm performance has been empirically justified through the analytical procedure of mediation analysis. Also, investigation based on multigroup analysis shows that the firms are different regarding utilization of resources and their strategies.

\subsubsection{Paper 1 (Chapter Two)}

From the paper, we can conclude that the application of strategic management practices indeed leads to better performance even in small agribusiness firms. The findings provide justification for the need of strategic management practices in competitive environments for survival of small agribusiness firms. Also, the argument that there is a need for strategic awareness not only in medium-sized and large enterprises but also in small ones (Beaver, 2007) is supported. Furthermore, our empirical findings are in line with earlier studies that have indicated the positive effects of systematic strategic management in small enterprises (R. Andrews et al., 2006; Bracker \& Pearson, 1986; Georgellis et al., 2000).

With reference to our research model, several factors from the internal and external environment of firm organizations are hypothesized to link positively with the ability to apply STM practices. These include firm attributes (i.e. firm age, size and formalization status) firms' internal resources (i.e. level of investment; access to market information and managerial expertise), and pressure from the external environment (i.e. level of 
production input availability, access to public infrastructure and access to external sources of funds). From the results of our model analysis, we conclude that all firm characteristics have a significant effect on STM practices whereby firm's formalization status has a greater impact followed by firm age and size. We imply that firms which are legally registered, are abiding to rules and procedures of business operations, are older and have high capital investments are more likely to have the ability to apply STM practices. The trend towards increasing formalization and implementation of management systems has been recently demonstrated for small growing enterprises as well (Davila, 2005). However, in the case of improving the formalization status of the firms, we should note that governments in developing countries often tolerate the operations of informal businesses due to their important contribution to net employment growth and poverty reductions (Nelson \& DeBruijn, 2005).

The study also indicates that that 'level of managerial expertise' mostly contributes to the application of STM practices. Firm managers and employees with relevant skills are in a good position to strategize well and position their products more easily in the market. The existing literature also indicates the same relationship, but with no clear indication of which skills are referred to (Ambrosini \& Bowman, 2009; Mugera, 2012). From our results we conclude that education on food quality and safety standards, food processing techniques and customer care are relevant for achieving firm strategy. In contrast, firms with inadequate skills cannot produce better strategic plans. The findings support the widely shared resource-based view that the intangible resources such as human resources provide bigger chances for achieving competitive advantages ${ }^{7}$ because these resources are often difficult to imitate or replace (Prahalad \& Hamel, 1990). Also, better access to information influences application of STM practices because firms with better information on where to purchase agricultural produce, product prices, sales channels, current customer needs, competitors' actions and other relevant topics have better opportunities to successfully engage in strategic actions than those with poor access to this information. Those with poor access to information are uninformed about what they need to solve their problems and unable to clearly understand market trends; as a result, they lose focus in goal accomplishment. Also, firms which have invested more

\footnotetext{
${ }^{7}$ A firm has a competitive advantage when it implements a strategy competitor are unable to duplicate or find too costly to try to imitate. If utilized properly, skilled employees can be one way for an organization to create a sustainable competitive advantage (Hitt et al., 2009).
} 
on assets and working equipment are better able to carry out their strategies than those with limited investment.

Similar arguments have been made in previous studies, which link the poor performance of many manufacturing firms to poor investment capacity (Dinh et al., 2013). Policy recommendations should aim to promote private investment and to resolve one of many small firm's major challenges - how to attract interested venture capitalists to allow investments into a modern production plants, machinery and food processing equipment.

Based on the factors from the external environment of the firm we conclude that not all external factors can impose pressure on firm managers to engage in strategic actions. For example access to external sources of funds helps managers to accomplish their strategies and at the same time it is the biggest challenge for those who do not have enough capital and are unable to secure funds from commercial banks. We conclude that small firm managers' improvement of access to loans can tremendously change the efficiency of firm operations. Competitive advantage is more prevalent in firms which have more alternatives for financing current and future activities. Firms with a lack of access to loans and complicated bank loan applications claimed that STM practices are expensive, irrelevant and time-consuming. Therefore, financial products should be improved to ensure that its access is responsive to the needs of small agribusiness firms. Other external factors such as better input availability and access to public infrastructure services do not necessarily impose pressure on firm managers to engage in strategic actions. Even though the relevant literature shows a positive link between access to input and STM practices, there was no statistical evidence in this study to support this conclusion. The reason is that the firms will either engage or fail to engage in strategic actions disregarding the status of road conditions, communication services, availability of harvest from farmers or availability of packaging materials from traders. Also, firms especially those selling in traditional markets are not too exposed to conditions in the external environment compared to large firms that deal with complex transport logistics and exporting.

\subsubsection{Paper 2 (Chapter Three)}

From the second paper, we can conclude that strategic management has a major role in facilitating effective use of resources to achieve firm performance. Firms' 
resources alone do not directly contribute to firm performance unless there is an environmental analysis activity conducted or a strategic plan created before using the resources. Most firms competing within a similar environment are assumed to possess similar types of resources; hence they are challenged to compete with each other in their pursuit of increasing performance.

Findings show that not all resources enhance firm performance. In paper 1, for example, managerial skills and access to market information were the critical resources in enhancing strategic actions. But in further analysis for this paper, the results indicate that managerial skills and access to market information do not significantly increase level of firm performance. The contribution is justified if the resources are paired up in firms' mission and vision statements or firms' commitment to implementation of strategies. That is why the relationship between resources and firm performance was analyzed in more detail through consideration of STM as a mediator. The results support and further explain the previous studies by Penrose $(1959,2009)$ which show that resources are not enough inputs for firm operations but that it is rather the way that these resources are used. It is even more advantageous when the resources are in line with firm's strategy (Edelman et al., 2005).

Small firms in developing countries such as Tanzania have often been operating without proper business plans. Workers thus operate blindly with poor knowledge on future business directions. The situation and the study analysis should alert policy makers to focus more on improving managerial style and capabilities particularly through promoting strategic management training. In our study we involved food processors which are mostly searching for market information to enhance their firm's survival, but since human beings have different abilities to process information (Simon, 1957), the access to market information alone might not be sufficient to achieve firm performance and sustainable competitive advantage as suggested by Barney \& Hesterly (2010). Therefore, this study analyzes the resources-performance link through application of STM practices as potential mediators.

\subsubsection{Case study (Chapter Four)}

The case briefly indicates a struggle from one of the agribusiness firms in Tanzania towards accomplishing a marketing strategy. It discusses several challenges surrounding 
business firms in the process of expanding the market for their food products. The typical challenges are based on;

(a) Stringent business regulations and operational charges imposed by the government.

(b) Poor availability of facilities to control losses and wastage (e.g. cold truck and cold room facilities) as well as inadequate preservation of fresh produces that are bought from farmers.

(c) Poor public infrastructure services (availability of electricity, road conditions, freight services, etc.).

(d) Dynamic market conditions, i.e. ever-changing customer preferences and inability to penetrate markets.

(e) Poor progress in implementation of policy recommendations for agribusiness development.

(f) Inadequate initiatives to share research results and transform them into actions. Also, poor collaboration between scientist, researchers and actors in food supply chains is a major challenge.

(g) Poor public-private partnership in preventing environmental pollution.

Considering the challenges, firms experience obstacles in implementing their strategies. More efforts should be made by firm managers to understand the environment through performing regular environmental analysis. Thereafter, there is the required basis for the design of alternative ways to minimize any risks caused by environmental threats. Also, more efforts should be put by the government into attempts to improve its obligations in managing fair competition in markets, providing better access to public services and market infrastructure, controlling food quality and safety, etc.

\subsection{Implications}

This study has both academic and practical implications. It adds to the literature that resources alone are not likely to contribute to firm performance if they are not aligned with firms strategy (Edelman et al., 2005; Edelman \& Brush, 2001). The firms should use their resources in line with strategies to cope with uncertain and dynamic 
environments. The key resources of firms are effective when balanced with the firms' plans indicated in mission, vision statement, business plan or firms' objectives. With this regard, managers are encouraged to choose resources that work best for their firms. Generally, our work contributes to the development of competency based competition (Prahalad \& Hamel, 1990) which calls for further expansion of specialized knowledge and skills that have 'value' to the firms' objectives. From the practical perspective, the managers can understand that engaging in strategic actions is beneficial to small firms as well (Beaver, 2007) and that it does not mean that the formal and complex procedure on papers are necessary at all times. The essential element is to develop a strategic plan that is known and communicated to every worker in the firm.

Furthermore, scholars should pursue the development of a portfolio of skills whereby technical skills on food processing should be balanced with the soft(er) marketing and management skills. After all, the products that are re-created from the production facilities are supposed to be sold in the markets. If the products are not successfully sold, then firms will need to reconsider their strategies and concentrate on developing unique skills that are needed to exploit food markets. We do not imply that there is a best skill or capability that matches every firm but rather suggest that a review of environmental analysis and planning can give best choice of essential skills. In this case, policy makers should take the engagement of strategic management skills into considerations while developing a plan of action (e.g., training programmes) that includes capacity building initiatives on organization management.

Care must be taken in order to avoid over-generalizing these results because further investigation from multigroup analysis indicate that our recommendations might not fit all types of agribusiness firms. Small firms are different and their paths to achieve sustainable growth are diverse (Chan et al., 2006). Results from group analysis indicate that we can distinguish between human-capital oriented firms, information dependent firms and strategic-oriented firms. The implication is that even though the firms are different in their strategies on using the available resources, they end up more similar in the way they achieve performance. Our findings are in line with Chan et al.'s (2006) suggestion that even though there are heterogeneous paths to sustainable growth, firms end up more similar to each other than they were when they started. Therefore, efforts should be made by firms to find a fit between their resources and strategic actions in order to enhance firm performance. 
In recent years, the development of the agribusiness sector has received much attention from governments. The Tanzanian government has targeted the country's manufacturing sector to increase its contribution to GDP from 8 to 15 percent between 2009 and 2015 (MoFEA 2010). Therefore, knowledge and skills on generating agricultural products of higher added value in a well-managed business firm should be promoted in this highly competitive environment. The research findings provide one of several routes to achieve performance through demonstrating the high importance of strategic management for the success of the agribusiness firms. and research findings translated into productive actions.

\subsection{Limitations and Further Research}

Overall, this research is an early inquiry into the strategic management process for firms of this nature in an emerging African economy. We based our research on the general fact that proper strategic plans and skills are needed to exploit food markets (Byerlee et al., 2013; Dietz et al., 2000; Dinh et al., 2013). This study faced some limitations in terms of scope because it focused mainly on a sample of agribusiness firms dealing with a limited range of processed food products (i.e. cereals, fruits and vegetables) in three out of 30 regions of Tanzania. For the purpose of generalization, future studies may want to include other regions and countries and both large and small firms in various food processing sub-sectors and beyond to broaden the scope of the study and improve its representativeness. Finally, the inclusion of resources other than level of managerial expertise and access to information in strategic actions as well as more complex combinations of resources might help to offer a deeper understanding on alternative pathways to improve firm performance. More progress surrounding the application of strategic management practices needs to be understood with the help of more in-depth case studies. Therefore, deeper qualitative explorations and analyses of longitudinal data are required in future research. 


\section{References}

Ambrosini, V., \& Bowman, C. (2009). What are dynamic capabilities and are they a useful construct in strategic management? International Journal of Management Reviews, 11(1), $29-49$.

Andrews, R., Boyne, G. A., \& Walker, R. M. (2006). Strategy content and organizational performance: An empirical analysis. Public Administration Review, 66(January-February), $52-63$.

Barney, J. B., \& Hesterly, W. S. (2010). Strategic management and competitive advantage concepts. Upper Saddle River, NJ: Pearson Prentice Hall.

Beaver, G. (2007). The strategy payoff for smaller enterprises. Journal of Business Strategy, 28(1), 11-17. Retrieved from http://www.emeraldinsight.com/10.1108/02756660710723161

Bracker, J. S., \& Pearson, J. N. (1986). Planning and Financial Performance of Small, Mature Firms. Strategic Management Journal, 7(6), 503-522.

Byerlee, D., Garcia, A. F., Giertz, A., \& Palmadesa, V. (2013). Growing Africa: Unlocking the Potential of Agribusiness. The World Bank. Retrieved August 17, 2014, from http://documents.worldbank.org/curated/en/2013/03/17427481/ growing-africa-unlockingpotential-agribusiness-vol-1-2-main-report

Chan, Y. E., Bhargava, N., \& Street, C. T. (2006). Having Arrived: The Homogeneity of HighGrowth Small Firms. Journal of Small Business Management, 44(3), 426-440.

Davila, T. (2005). An exploratory study on the emergence of management control systems: Formalizing human resources in small growing firms. Accounting, Organizations and Society, 30(3), 223-248. Retrieved from http://linkinghub.elsevier.com/retrieve/pii/S036136820400042X

Dietz, M. H., Matee, S., \& Ssali, W. (2000). Assessment of the Small-scale Food Processing Subsector in Tanzania and Uganda: Study Report (p. 65). The Technical Centre for Agricultural and Rural Cooperation CTA, Wageningen, Netherlands.

Dinh, H. T., Monga, C., Morisset, J., Kweka, J., Yagci, F., \& Yoshino, Y. (2013). Light manufacturing in Tanzania: A reform agenda for job creation and prosperity (p. 116). Washington DC 20001: The World Bank.

Edelman, L. F., \& Brush, C. G. (2001). The Mediating Role of Strategy on Small Firm Performance. 2001 Academy of Management Research Conference (p. 50). Waltham, MA 02453.

Edelman, L. F., Brush, C. G., \& Manolova, T. (2005). Co-alignment in the resource-performance relationship: strategy as mediator. Journal of Business Venturing, 20(3), 359-383.

Georgellis, Y., Joyce, P., \& Woods, A. (2000). Entrepreneurial action, innovation and business performance: The small independent business. Journal of Small Business and Enterprise Development, 7(1), 7-17.

Ministry of Finance and Economic Affairs. (2010). National Strategy for Growth and Reduction of Poverty II: NSGRP II. Retrieved July 20, 2014, from http://www.acdi- 
cida.gc.ca/INET/IMAGES.NSF/vLUImages/Tanzania/\$file/NATIONAL-STRATEGYFOR-GROWTH-AND-REDUCTION-OF-POVERTY-TANZANIA.PDF

Mugera, A. W. (2012). Sustained Competitive Advantage in Agribusiness: Applying the Resource-based Theory to Human Resources. International Food and Agribusiness Management Review, 15(4), 27-48.

Nelson, E. G., \& DeBruijn, E. J. (2005). The Voluntary Formalization of Enterprises in a Developing Economy - The Case of Tanzania. Journal of International Development, 17(4), 575-593.

Penrose, E. T. (1959). The Theory of the Growth of the Firm. Oxford: Basil Blackwell.

Penrose, E. T. (2009). The Theory of the Growth of the Firm: With a New Introduction by Christos N. Pitelis (Fourth., p. 249). Oxford: Oxford University Press.

Prahalad, C. K., \& Hamel, G. (1990). The Core Competence of the Corporation. Harvard Business Review, 68(3), 79-91.

Simon, H. A. (1957). Models of Man: Social and Rational (p. 279). New York: John Wiley \& Sons, Inc. 


\section{Survey Instrument}

Georg-August-Universität

Department of Agricultural Economics and Rural Development Tanzania Agribusiness Firm Survey 2013

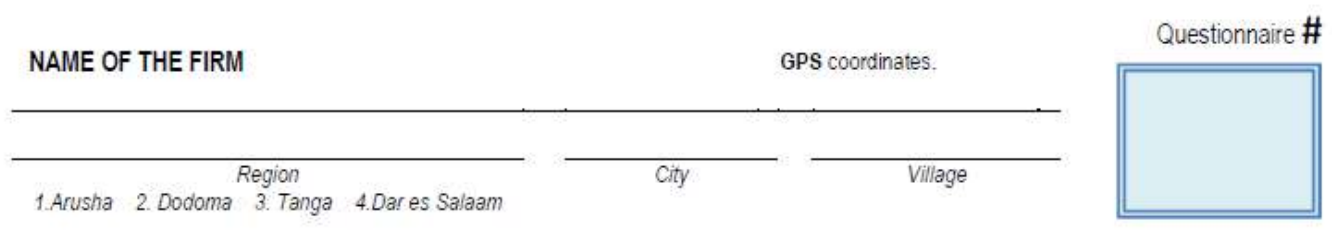

Address of the Firm:

Phone :

\begin{tabular}{l|l|l}
\multicolumn{2}{l|}{ INTERVIEWER } & ID No. \\
\hline \multicolumn{2}{c}{ Name and Signature } & - \\
\hline Visit 1 & Date \& Duration of Interview: \\
\hline Visit 2 & Date \& Duration of Interview: \\
\hline
\end{tabular}

Notes

\begin{tabular}{|c|c|c|}
\hline \multicolumn{2}{|c|}{ DATA ENTRANT } & \multirow{2}{*}{$\mid \begin{array}{c}\text { ID No. } \\
--\end{array}$} \\
\hline & Name and Signature & \\
\hline Data entered & & (if yes put a $\sqrt{ }$ mark) \\
\hline Date Checked & & (if yes put a $\sqrt{ }$ mark) \\
\hline Status & Good $\square$ & $\square$ \\
\hline
\end{tabular}

\begin{tabular}{l|l|l} 
RESEARCHER & ID No. \\
\hline \multicolumn{3}{|c|}{ Name and Signature } \\
\hline Date Checked & & \\
\hline Date Checked & & \\
\hline Status & Approved [ ] Not approved [ ] \\
\hline
\end{tabular}




\section{Part I: Respondent's Profile}

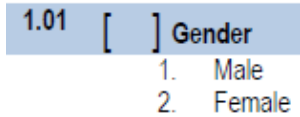

1.05

\section{What is your age?}

years
1.02

] Education

1. Never attended school

2. Primary schooling

3. Secondary schooling

College certificate

5. Degree

6. Other

1.04 Total years of education

1.06 Number of years of working in the firm

years months
1.03

Position in the firm

1. Owner

2. Managing Director

3. Both $1 \& 2$

4. Business Partner

5. Employee

6. Other

1.07 What was your previous work status before working in this firm? [ ]

1. Employed (Public organization)

2. Employed (Private organization)

3. Student

4. Housewife (for female)

5. Unemployed

1.08 How many languages are you familiar with? Local

Foreign Please choose;

1.Swahili [ ] 2. English [ ] 3. Other

[ ] 4. Other

[ ]

\begin{tabular}{|c|c|c|c|c|c|c|c|}
\hline \multicolumn{3}{|c|}{1.09 Major foreign language competence } & Not very well & Not well & Intermediar & Well & Very well \\
\hline 1. & \multicolumn{2}{|l|}{ I can write in English. } & $\square$ & $\square$ & $\square$ & $\square$ & $\square$ \\
\hline 2. & \multicolumn{2}{|l|}{ I can understand English. } & $\square$ & $\square$ & $\square$ & $\square$ & $\square$ \\
\hline 3. & \multicolumn{2}{|l|}{ I can read English. } & $\square$ & $\square$ & $\square$ & $\square$ & $\square$ \\
\hline 4. & \multicolumn{2}{|l|}{ I can speak English. } & $\square$ & $\square$ & $\square$ & $\square$ & $\square$ \\
\hline \multirow{2}{*}{\multicolumn{2}{|c|}{$\begin{array}{l}1.10 \text { On a scale of } 1 \text { to } 5 \text {, please rate your } \\
\text { level of expertise in the following subjects } \\
\text { (consider all employees in the firm) }\end{array}$}} & & $\begin{array}{l}\text { Need some } \\
\text { improvement }\end{array}$ & Average & Very good & & $\begin{array}{c}\text { Not } \\
\text { applicable }\end{array}$ \\
\hline & & 1 & 2 & 3 & 4 & 5 & \\
\hline 1. & Bookkeeping and accounting & $\square$ & $\square$ & $\square$ & $\square$ & $\square$ & $\square$ \\
\hline 2. & Managing employees & $\square$ & $\square$ & $\square$ & $\square$ & $\square$ & $\square$ \\
\hline 3. & Marketing techniques & $\square$ & $\square$ & $\square$ & $\square$ & $\square$ & $\square$ \\
\hline 4. & Financial management & $\square$ & $\square$ & $\square$ & $\square$ & $\square$ & $\square$ \\
\hline 5. & Stock taking \& Record keeping & $\square$ & $\square$ & $\square$ & $\square$ & $\square$ & $\square$ \\
\hline 6. & Food quality \& Safety standards & $\square$ & $\square$ & $\square$ & $\square$ & $\square$ & $\square$ \\
\hline 7. & Customer care & $\square$ & $\square$ & $\square$ & $\square$ & $\square$ & $\square$ \\
\hline 8. & Product presentation & $\square$ & $\square$ & $\square$ & $\square$ & $\square$ & $\square$ \\
\hline 9. & Food Processing & $\square$ & $\square$ & $\square$ & $\square$ & $\square$ & $\square$ \\
\hline 10. & Other & $\square$ & $\square$ & $\square$ & $\square$ & $\square$ & $\square$ \\
\hline 11. & Other ______ & $\square$ & $\square$ & $\square$ & $\square$ & $\square$ & $\square$ \\
\hline
\end{tabular}

1.11 (if the respondent is not the owner)

Does the owner of the business participate in daily firm operations?

Yes $=1$ No $=0$

[ ] 
Questionnaire \#

\section{Part II: Firm's Profile}

\subsection{What is the location of the firm? [ ]}

1. Major city

2. Secondary City

3. Rural Area
2.2 Age of the business

years

months

2.4 [ ] is it a family business?

1. Yes

2. No
2.3 [ ] Status of the business

1. Private Limited

2. Partnership

3. Public limited

4. Others

2.5 Additional number of owners

$\begin{array}{ll} & \text { Number of workers } \\ 2.06 & \text { Full time employees } \\ 2.07 & \text { Part time employees }\end{array}$

2.10 Capital Investment
2.09 Exporting activity [ ]

0. Do not export

约

हो

\begin{tabular}{l|l|l|l|l}
2.11 Statements & $\begin{array}{c}\text { Strongly } \\
\text { disagree }\end{array}$ & Disagree & $\begin{array}{c}\text { Neither agree } \\
\text { nor disagree }\end{array}$ & $\begin{array}{c}\text { Agree } \\
\text { agree }\end{array}$ \\
\hline a. You have a picture of an organization structure & & & & \\
\hline b. You have indicated clearly the division of work for employees & & & & \\
\hline c. You have written a clear business plan & & & & \\
\hline d. You are able to abide to all legal business regulations & & & &
\end{tabular}

\begin{tabular}{|c|c|c|c|c|}
\hline 2.12 & Name of product & $\begin{array}{l}\text { Product nature } \\
(1=\text { Cereals } 2=\text { Fruits } 3= \\
\text { Vegetables } 4=\text { others })\end{array}$ & $\begin{array}{l}1=\text { Perishable } \\
2=\text { Non- perishable }\end{array}$ & $\begin{array}{l}\text { Primary raw mat } \\
1=\text { Domestic far } \\
2=\text { Imported }\end{array}$ \\
\hline & Product 1 & & & \\
\hline & Product 2 & & & \\
\hline & Product 3 & & & \\
\hline & Product 4 & & & \\
\hline & Product 5 & & & \\
\hline & Product 6 & & & \\
\hline
\end{tabular}




\section{Part III: Firm Resources and Internal Environment}

\begin{tabular}{|c|c|c|c|c|c|c|c|}
\hline $\begin{array}{l}3.01 \text { How high have you invested in } \\
\text { the following items }\end{array}$ & $\begin{array}{c}\text { Very Low } \\
\text { (up to } \\
0 \% \text { ) }\end{array}$ & $\begin{array}{l}\text { Low } \\
(25 \%)\end{array}$ & $\begin{array}{l}\text { Average } \\
(50 \%)\end{array}$ & $\begin{array}{l}\text { High } \\
(75 \%)\end{array}$ & $\begin{array}{c}\text { Very high } \\
\text { (up to } \\
100 \% \text { ) }\end{array}$ & $\begin{array}{l}\text { Not } \\
\text { applicable }\end{array}$ & $\begin{array}{l}\text { I don't } \\
\text { know }\end{array}$ \\
\hline Firm building(s) & $\square$ & $\square$ & $\square$ & $\square$ & $\square$ & $\square$ & $\square$ \\
\hline Motor Vehicle(s) & $\square$ & $\square$ & $\square$ & $\square$ & $\square$ & $\square$ & $\square$ \\
\hline Employees' training & $\square$ & $\square$ & $\square$ & $\square$ & $\square$ & $\square$ & $\square$ \\
\hline Production technology & $\square$ & $\square$ & $\square$ & $\square$ & $\square$ & $\square$ & $\square$ \\
\hline Office tools & $\square$ & $\square$ & $\square$ & $\square$ & $\square$ & $\square$ & $\square$ \\
\hline Marketing activities & $\square$ & $\square$ & $\square$ & $\square$ & $\square$ & $\square$ & $\square$ \\
\hline Others_ & $\square$ & $\square$ & $\square$ & $\square$ & $\square$ & $\square$ & $\square$ \\
\hline Others & $\square$ & $\square$ & $\square$ & $\square$ & $\square$ & $\square$ & $\square$ \\
\hline
\end{tabular}

\begin{tabular}{l|l|l|l|l|l|l|l|l|}
$\begin{array}{l}\text { 3.02 Please indicate major raw materials } \\
\text { (inputs) for your production facility. Then } \\
\text { rate how accessible they are to your firm }\end{array}$ & \multicolumn{2}{|c|}{$\begin{array}{l}\text { Not } \\
\text { accessible }\end{array}$} & $\begin{array}{c}\text { Highly } \\
\text { accessible }\end{array}$ & $\begin{array}{c}\text { Not don't } \\
\text { applicable } \\
\text { know }\end{array}$ \\
\hline 1. & Agricultural inputs & $\square$ & $\square$ & $\square$ & $\square$ & $\square$ & $\square$ \\
\hline 2. & Non-Agricultural inputs & $\square$ & $\square$ & $\square$ & $\square$ & $\square$ & $\square$ \\
\hline 3. & Others & $\square$ & $\square$ & $\square$ & $\square$ & $\square$ & $\square$ \\
\hline
\end{tabular}

3.03 Please rate overall level of technology of the production facility.

(Use a rating scale, where $1=$ Not technical, traditional technology and $5=$ Very technical, advanced technology).

Note

When the facility stechnology can be replaced with something newer, better and faster. Then the existing becomes outdated, depending on the version.

Modern facility is energy efficient, portable, faster processing ability and long-lasting

\begin{tabular}{|c|c|c|c|c|c|c|c|}
\hline \multicolumn{2}{|c|}{$\begin{array}{l}3.04 \text { Please rate the extent of ICT use } \\
\text { in your food manufacturing operations }\end{array}$} & Never & $\begin{array}{l}\text { Once a } \\
\text { week }\end{array}$ & $\begin{array}{l}2 \text { times a } \\
\text { week }\end{array}$ & $\begin{array}{l}3 \text { times a } \\
\text { week }\end{array}$ & Daily & $\begin{array}{l}\text { Not } \\
\text { applicable }\end{array}$ \\
\hline 1. & Telephones & $\square$ & $\square$ & $\square$ & $\square$ & $\square$ & $\square$ \\
\hline 2. & Desktop computer & $\square$ & $\square$ & $\square$ & $\square$ & $\square$ & $\square$ \\
\hline 3. & Laptop personal computer & $\square$ & $\square$ & $\square$ & $\square$ & $\square$ & $\square$ \\
\hline 4. & Photocopier & $\square$ & $\square$ & $\square$ & $\square$ & $\square$ & $\square$ \\
\hline 5. & The internet (Email) & $\square$ & $\square$ & $\square$ & $\square$ & $\square$ & $\square$ \\
\hline 6. & Scanner & $\square$ & $\square$ & $\square$ & $\square$ & $\square$ & $\square$ \\
\hline 7. & Telefax & $\square$ & $\square$ & $\square$ & $\square$ & $\square$ & $\square$ \\
\hline 8. & Others & $\square$ & $\square$ & $\square$ & $\square$ & $\square$ & $\square$ \\
\hline 9. & Others & $\square$ & $\square$ & $\square$ & $\square$ & $\square$ & $\square$ \\
\hline
\end{tabular}

\begin{tabular}{l|l|l|l|l|l|l|l|}
$\begin{array}{l}3.05 \text { Which among the } \\
\text { following information is } \\
\text { accessible to you? }\end{array}$ & $\begin{array}{l}\text { Completely } \\
\text { inaccessible }\end{array}$ & & $\square$ & $\square$ & $\square$ & $\begin{array}{c}\text { Highly } \\
\text { accessible } \\
\text { applicable } \\
\text { know }\end{array}$ \\
\hline Where to get raw materials & $\square$ & $\square$ & $\square$ & $\square$ & $\square$ \\
\hline Changes in product prices & $\square$ & $\square$ & $\square$ & $\square$ & $\square$ & $\square$ \\
\hline Where to sell & $\square$ & $\square$ & $\square$ & $\square$ & $\square$ & $\square$
\end{tabular}


Questionnaire \#

Respondent \#

Customers' whereabouts

When to sell

Competitors' information

Tax rates

Trade associations

Others

\section{ins}

品

\begin{tabular}{l|l|l|l}
$\square$ & $\square$ & $\square$ & $\square$ \\
$\square$ & $\square$ & $\square$ & $\square$ \\
$\square$ & $\square$ & $\square$ & $\square$ \\
$\square$ & $\square$ & $\square$ & $\square$ \\
\hline$\square$ & $\square$ & $\square$ & $\square$
\end{tabular}

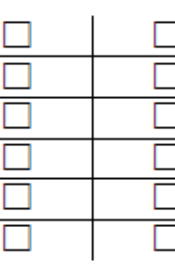

\begin{tabular}{l|l}
$\square$ & $\square$ \\
\hline$\square$ & $\square$ \\
\hline$\square$ & $\square$ \\
\hline$\square$ & $\square$ \\
\hline$\square$ & $\square$ \\
\hline$\square$ & $\square$
\end{tabular}

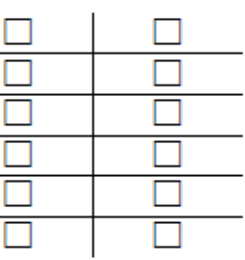

\begin{tabular}{|c|c|c|c|c|c|c|c|}
\hline $\begin{array}{l}3.06 \text { How do you rate the expertise } \\
\text { level of your firm the following } \\
\text { areas? }\end{array}$ & $\begin{array}{l}\text { Not } \\
\text { trained a } \\
\text { all }\end{array}$ & & & & $\begin{array}{l}\text { Highly } \\
\text { trained }\end{array}$ & $\begin{array}{l}\text { Not } \\
\text { applicable }\end{array}$ & $\begin{array}{l}\text { I don't } \\
\text { know }\end{array}$ \\
\hline Bookkeeping & $\square$ & $\square$ & $\square$ & $\square$ & $\square$ & $\square$ & $\square$ \\
\hline People management & $\square$ & $\square$ & $\square$ & $\square$ & $\square$ & $\square$ & $\square$ \\
\hline Marketing techniques & $\square$ & $\square$ & $\square$ & $\square$ & $\square$ & $\square$ & $\square$ \\
\hline Financial management & $\square$ & $\square$ & $\square$ & $\square$ & $\square$ & $\square$ & $\square$ \\
\hline Record keeping & $\square$ & $\square$ & $\square$ & $\square$ & $\square$ & $\square$ & $\square$ \\
\hline Accounting & $\square$ & $\square$ & $\square$ & $\square$ & $\square$ & $\square$ & $\square$ \\
\hline Customer care & $\square$ & $\square$ & $\square$ & $\square$ & $\square$ & $\square$ & $\square$ \\
\hline Product presentation & $\square$ & $\square$ & $\square$ & $\square$ & $\square$ & $\square$ & $\square$ \\
\hline Food Processing & $\square$ & $\square$ & $\square$ & $\square$ & $\square$ & $\square$ & $\square$ \\
\hline Other & $\square$ & $\square$ & $\square$ & $\square$ & $\square$ & $\square$ & $\square$ \\
\hline Other & $\square$ & $\square$ & $\square$ & $\square$ & $\square$ & $\square$ & $\square$ \\
\hline
\end{tabular}

\begin{tabular}{|c|c|}
\hline Self-financing & $=1$ \\
\hline Short term loan (less than 1 year) & $=2$ \\
\hline Long term loan (more than 1 year) & $=3$ \\
\hline Funds from a shareholder & $=4$ \\
\hline Other, specify & $=5$ \\
\hline
\end{tabular}

\begin{tabular}{|c|c|c|c|c|c|c|c|}
\hline $\begin{array}{l}3.08 \text { In the process of applying for a } \\
\text { loan, to finance your firm activities } \\
\text { and other investments, how do you } \\
\text { rate the following sources? }\end{array}$ & Very poor & Poor & Fair & Good & Very good & $\begin{array}{l}\text { I don't } \\
\text { know }\end{array}$ & N/A \\
\hline Individual money lender & $\square$ & $\square$ & $\square$ & $\square$ & $\square$ & $\square$ & $\square$ \\
\hline Rural private bank & $\square$ & $\square$ & $\square$ & $\square$ & $\square$ & $\square$ & $\square$ \\
\hline Urban private bank & $\square$ & $\square$ & $\square$ & $\square$ & $\square$ & $\square$ & $\square$ \\
\hline Cooperative bank & $\square$ & $\square$ & $\square$ & $\square$ & $\square$ & $\square$ & $\square$ \\
\hline Community funds & $\square$ & $\square$ & $\square$ & $\square$ & $\square$ & $\square$ & $\square$ \\
\hline Government bank & $\square$ & $\square$ & $\square$ & $\square$ & $\square$ & $\square$ & $\square$ \\
\hline Private organization & $\square$ & $\square$ & $\square$ & $\square$ & $\square$ & $\square$ & $\square$ \\
\hline Other & $\square$ & $\square$ & $\square$ & $\square$ & $\square$ & $\square$ & $\square$ \\
\hline Other & $\square$ & $\square$ & $\square$ & $\square$ & $\square$ & $\square$ & $\square$ \\
\hline
\end{tabular}




\section{Part IV: External Environment}

\begin{tabular}{|c|c|c|c|c|c|c|c|c|}
\hline \multicolumn{2}{|c|}{$\begin{array}{l}4.01 \text { On a scale of } 1 \text { to } 5 \text {, please rate } \\
\text { availability of inputs that your } \\
\text { production facility will need for future } \\
\text { production }\end{array}$} & $\begin{array}{l}\text { Not } \\
\text { availabl } \\
\text { e }\end{array}$ & \multicolumn{2}{|l|}{10} & \multicolumn{2}{|c|}{$\begin{array}{l}\text { Highly } \\
\text { available }\end{array}$} & \multirow{2}{*}{$\begin{array}{c}\begin{array}{c}\text { Not } \\
\text { applicable }\end{array} \\
\square\end{array}$} & \multirow{2}{*}{$\begin{array}{c}\text { I don't } \\
\text { know } \\
\\
\square \\
\end{array}$} \\
\hline 1. & Agricultural inputs & $\square$ & $\square$ & $\square$ & $\square$ & $\square$ & & \\
\hline 2. & Non-Agricultural inputs & $\square$ & $\square$ & $\square$ & $\square$ & $\square$ & $\square$ & $\square$ \\
\hline 3. & Others & $\square$ & $\square$ & $\square$ & $\square$ & $\square$ & $\square$ & $\square$ \\
\hline $\begin{array}{l}4.02 \mathrm{~W} \\
\text { import }\end{array}$ & $\begin{array}{l}\text { hich among the following is an } \\
\text { int selling point for your firm? }\end{array}$ & $\begin{array}{l}\text { Not at all } \\
\text { important }\end{array}$ & $\begin{array}{l}\text { Not } \\
\text { important }\end{array}$ & Neutral & Important & $\begin{array}{l}\text { Very } \\
\text { important }\end{array}$ & $\begin{array}{l}\text { I don't } \\
\text { know }\end{array}$ & N/A \\
\hline 1. & Neighborhood area & $\square$ & $\square$ & $\square$ & $\square$ & $\square$ & $\square$ & $\square$ \\
\hline 2. & Traditional food market & $\square$ & $\square$ & $\square$ & $\square$ & $\square$ & $\square$ & $\square$ \\
\hline 3. & Grocery stores & $\square$ & $\square$ & $\square$ & $\square$ & $\square$ & $\square$ & $\square$ \\
\hline 4. & Supermarket (all types) & $\square$ & $\square$ & $\square$ & $\square$ & $\square$ & $\square$ & $\square$ \\
\hline 5. & Wholesale markets & $\square$ & $\square$ & $\square$ & $\square$ & $\square$ & $\square$ & $\square$ \\
\hline 6. & Restaurants, schools and workplaces & $\square$ & $\square$ & $\square$ & $\square$ & $\square$ & $\square$ & $\square$ \\
\hline 7. & International markets & $\square$ & $\square$ & $\square$ & $\square$ & $\square$ & $\square$ & $\square$ \\
\hline 8. & Others_ & $\square$ & $\square$ & $\square$ & $\square$ & $\square$ & $\square$ & $\square$ \\
\hline
\end{tabular}

\begin{tabular}{l|c|c|c|c|c|c|c}
$\begin{array}{l}4.03 \text { How do you rate the level of competition } \\
\text { from; }\end{array}$ & $\begin{array}{c}\text { Very } \\
\text { weak }\end{array}$ & Weak & Average & Strong & $\begin{array}{c}\text { Very } \\
\text { strong }\end{array}$ & $\begin{array}{c}\text { Idon't } \\
\text { know }\end{array}$ & $\begin{array}{c}\text { Not } \\
\text { applicable }\end{array}$ \\
\hline Domestic firms & 1 & 2 & 3 & 4 & 5 & 0 & \\
\hline Foreign firms in local markets & 1 & 2 & 3 & 4 & 5 & 0 & \\
\hline Importing firms & 1 & 2 & 3 & 4 & 5 & 0 & \\
\hline Others & 1 & 2 & 3 & 4 & 5 & 0 &
\end{tabular}

\begin{tabular}{l|c|c|c|c|c}
$\begin{array}{l}\text { 4.04 Please indicate your attitude towards } \\
\text { accessing different public infrastructure \& } \\
\text { services to the firm }\end{array}$ & $\begin{array}{c}\text { Strongly } \\
\text { disagree }\end{array}$ & $\begin{array}{c}\text { Neither } \\
\text { agree nor } \\
\text { disagree }\end{array}$ & $\begin{array}{c}\text { Agree } \\
\text { Strongly } \\
\text { agree }\end{array}$ & $\begin{array}{c}\text { Not } \\
\text { applicable }\end{array}$ \\
\hline The firm is located along the regional highway road & $\square$ & $\square$ & $\square$ & $\square$ & $\square$ \\
\hline The firm is at the city center & $\square$ & $\square$ & $\square$ & $\square$ & $\square$ \\
\hline There is access to telephone services & $\square$ & $\square$ & $\square$ & $\square$ & $\square$ \\
\hline There is access to electricity & $\square$ & $\square$ & $\square$ & $\square$ & $\square$ \\
\hline There is access to water & $\square$ & $\square$ & $\square$ & $\square$ \\
\hline There is continuous phone services & $\square$ & $\square$ & $\square$ & $\square$ & $\square$ \\
\hline $\begin{array}{l}\text { There is continuous and uninterrupted electricity } \\
\text { supply }\end{array}$ & $\square$ & $\square$ & $\square$ & $\square$ & $\square$ \\
\hline $\begin{array}{l}\text { There is continuous and uninterrupted water } \\
\text { supply }\end{array}$ & $\square$ & $\square$ & $\square$ & $\square$ & $\square$ \\
\hline
\end{tabular}

\section{Environmental conditions}

4.05 Distance from production facility to main road

4.07 Distance from production facility to the nearest major market

4.08 Electricity interruptions

4.09 Social violence in community

${ }_{\mathrm{km}}^{\mathrm{km}}$ 4.06 Travel time __ hours __ minutes

Occurence per month

Number of incidences per month 
$1=$ Very inconvenient

$2=$ Inconvenient

$3=$ Neutral

$4=$ Convenient

$5=$ Very convenient

\section{Part V: Strategic Management Practices}

The following are the statements describing activities that firms perform in managing their strategies. Please rate from 'strongly disagree' to 'strongly agree' and NA if 'not applicable'

\begin{tabular}{l|c|c|c|c|c|c|c} 
5.01 Environmental scanning activities & $\begin{array}{c}\text { Strongly } \\
\text { disagree }\end{array}$ & Disagree & $\begin{array}{c}\text { Neither } \\
\text { agree nor } \\
\text { disagree }\end{array}$ & Agree & $\begin{array}{c}\text { Strongly } \\
\text { agree }\end{array}$ & $\begin{array}{c}\text { Idon't } \\
\text { know }\end{array}$ & N/A \\
\hline $\begin{array}{l}\text { You have developed a list of strengths and } \\
\text { weaknesses (of the firm) }\end{array}$ & $\square$ & $\square$ & $\square$ & $\square$ & $\square$ & $\square$ & $\square$ \\
\hline $\begin{array}{l}\text { You are informed about all opportunities that } \\
\text { are good for firm development. }\end{array}$ & $\square$ & $\square$ & $\square$ & $\square$ & $\square$ & $\square$ & $\square$ \\
\hline $\begin{array}{l}\text { You understand your customers and which } \\
\text { products they need }\end{array}$ & $\square$ & $\square$ & $\square$ & $\square$ & $\square$ & $\square$ & $\square$
\end{tabular}

\begin{tabular}{l|c|c|c|c|c|c|c}
$\mathbf{5 . 0 2}$ Planning activities & $\begin{array}{c}\text { Strongly } \\
\text { disagree }\end{array}$ & Disagree & $\begin{array}{c}\text { Neither } \\
\text { agree nor } \\
\text { disagree }\end{array}$ & Agree & $\begin{array}{c}\text { Strongly } \\
\text { agree }\end{array}$ & $\begin{array}{c}\text { I don't } \\
\text { know }\end{array}$ & N/A \\
\hline $\begin{array}{l}\text { You have visualized what your firm might be } \\
\text { like 5 to 10 years from now }\end{array}$ & $\square$ & $\square$ & $\square$ & $\square$ & $\square$ & $\square$ & $\square$ \\
\hline You have developed a list of firms' objectives & $\square$ & $\square$ & $\square$ & $\square$ & $\square$ & $\square$ & $\square$ \\
\hline The objectives are regularly updated & $\square$ & $\square$ & $\square$ & $\square$ & $\square$ & $\square$ & $\square$ \\
\hline The objectives are known to every employee & $\square$ & $\square$ & $\square$ & $\square$ & $\square$ & $\square$ & $\square$
\end{tabular}

\begin{tabular}{l|c|c|c|c|c|c|c}
$\mathbf{5 . 0 3}$ Implementation & $\begin{array}{c}\text { Strongly } \\
\text { disagree }\end{array}$ & Disagree & $\begin{array}{c}\text { Neither } \\
\text { agree nor } \\
\text { disagree }\end{array}$ & Agree & $\begin{array}{c}\text { Strongly } \\
\text { agree }\end{array}$ & $\begin{array}{c}\text { I don't } \\
\text { know }\end{array}$ & N/A \\
\hline $\begin{array}{l}\text { You have fully developed operational } \\
\text { procedures manual }\end{array}$ & $\square$ & $\square$ & $\square$ & $\square$ & $\square$ & $\square$ & $\square$ \\
\hline $\begin{array}{l}\text { The procedures of work are fully } \\
\text { communicated }\end{array}$ & $\square$ & $\square$ & $\square$ & $\square$ & $\square$ & $\square$ & $\square$
\end{tabular}


Questionnaire \#

Respondent \#

Interviewer ID

\begin{tabular}{l|c|c|c|c|c|c|c}
$\begin{array}{l}\text { The procedures are fully understood by every } \\
\text { employee }\end{array}$ & $\square$ & $\square$ & $\square$ & $\square$ & $\square$ & $\square$ & $\square$ \\
\hline $\begin{array}{l}\text { The firm can afford to finance actual } \\
\text { implementation of strategies }\end{array}$ & $\square$ & $\square$ & $\square$ & $\square$ & $\square$ & $\square$ & $\square$ \\
\hline $\begin{array}{l}\text { The employees are fully committed on } \\
\text { implementation of strategies }\end{array}$ & $\square$ & $\square$ & $\square$ & $\square$ & $\square$ & $\square$ & $\square$ \\
\hline $\begin{array}{l}\text { There is adequate number of staff to } \\
\text { implement firm strategies }\end{array}$ & $\square$ & $\square$ & $\square$ & $\square$ & $\square$ & $\square$ & $\square$ \\
\hline $\begin{array}{l}\text { There is enough competencies to implement } \\
\text { the strategies }\end{array}$ & $\square$ & $\square$ & $\square$ & $\square$ & $\square$ & $\square$ & $\square$
\end{tabular}

\begin{tabular}{l|c|c|c|c|c|c|c} 
5.04 Evaluation and control & $\begin{array}{c}\text { Strongly } \\
\text { disagree }\end{array}$ & Disagree & $\begin{array}{c}\text { Neither } \\
\text { agree nor } \\
\text { disagree }\end{array}$ & Agree & $\begin{array}{c}\text { Strongly } \\
\text { agree }\end{array}$ & $\begin{array}{c}\text { Idon't } \\
\text { know }\end{array}$ & N/A \\
\hline $\begin{array}{l}\text { You regularly compare your activities to your } \\
\text { plans }\end{array}$ & $\square$ & $\square$ & $\square$ & $\square$ & $\square$ & $\square$ & $\square$ \\
\hline $\begin{array}{l}\text { You develop alternative plans } \\
\text { You regularly compare your strategies with } \\
\text { your competitors' }\end{array}$ & $\square$ & $\square$ & $\square$ & $\square$ & $\square$ & $\square$ & $\square$ \\
\hline
\end{tabular}

\begin{tabular}{|c|c|c|c|c|c|c|}
\hline \multirow{2}{*}{\multicolumn{2}{|c|}{$\begin{array}{l}5.05 \text { Are you familiar with the following } \\
\text { business tools? } \\
\qquad\left(1=Y_{\text {es }} 2=\text { No) }\right.\end{array}$}} & \multicolumn{5}{|c|}{5.06 How often do you use them? } \\
\hline & & \multirow{2}{*}{$\begin{array}{c}\text { Never } \\
\square\end{array}$} & \multirow{2}{*}{$\begin{array}{c}\text { Seldom } \\
\square\end{array}$} & \multirow{2}{*}{$\begin{array}{c}\text { Occasionally } \\
\square\end{array}$} & \multirow{2}{*}{$\begin{array}{c}\text { Frequently } \\
\square \square\end{array}$} & \multirow{2}{*}{$\begin{array}{c}\text { Always } \\
\square\end{array}$} \\
\hline a Balance sheet & [ ] & & & & & \\
\hline b Profit and loss statement & [ ] & $\square$ & $\square$ & $\square$ & $\square$ & $\square$ \\
\hline c Cash flow & [ ] & $\square$ & $\square$ & $\square$ & $\square$ & $\square$ \\
\hline d Sales trend projections & [ ] & $\square$ & $\square$ & $\square$ & $\square$ & $\square$ \\
\hline e Cost benefit ratio analysis & [ ] & $\square$ & $\square$ & $\square$ & $\square$ & $\square$ \\
\hline f Performance appraisal & [ ] & $\square$ & $\square$ & $\square$ & $\square$ & $\square$ \\
\hline g Risk analysis & [ ] & $\square$ & $\square$ & $\square$ & $\square$ & $\square$ \\
\hline h Net present value (NPV) & [ ] & $\square$ & $\square$ & $\square$ & $\square$ & $\square$ \\
\hline i Brainstorming & [ ] & $\square$ & $\square$ & $\square$ & $\square$ & $\square$ \\
\hline $\begin{array}{l}\text { j Analysis of firm's strength, } \\
\text { weaknesses, opportunities and } \\
\text { threats (SWOT) }\end{array}$ & [ ] ] & $\square$ & $\square$ & $\square$ & $\square$ & $\square$ \\
\hline
\end{tabular}

\begin{tabular}{|c|c|c|c|c|c|c|c|}
\hline $\begin{array}{l}5.06 \text { To what extent do you agree or disagree } \\
\text { with the following statements; }\end{array}$ & $\begin{array}{l}\text { Strongly } \\
\text { disagree }\end{array}$ & Disagree & $\begin{array}{l}\text { Neither } \\
\text { agree nor } \\
\text { disagree }\end{array}$ & Agree & $\begin{array}{c}\text { Strongly } \\
\text { agree }\end{array}$ & $\begin{array}{l}\text { Idon't } \\
\text { know }\end{array}$ & N/A \\
\hline a.You continually redefine your service priorities & $\square$ & $\square$ & $\square$ & $\square$ & $\square$ & $\square$ & $\square$ \\
\hline $\begin{array}{l}\text { b. You seek to be the first to identify new modes of } \\
\text { delivery }\end{array}$ & $\square$ & $\square$ & $\square$ & $\square$ & $\square$ & $\square$ & $\square$ \\
\hline $\begin{array}{l}\text { c. Searching for new opportunities is a major part of } \\
\text { your overall strategy }\end{array}$ & $\square$ & $\square$ & $\square$ & $\square$ & $\square$ & $\square$ & $\square$ \\
\hline $\begin{array}{l}\text { d.You often change your focus to new market } \\
\text { areas }\end{array}$ & $\square$ & $\square$ & $\square$ & $\square$ & $\square$ & $\square$ & $\square$ \\
\hline e.You seek to maintain stable service priorities & $\square$ & $\square$ & $\square$ & $\square$ & $\square$ & $\square$ & $\square$ \\
\hline f. The service emphasizes efficiency of provision & $\square$ & $\square$ & $\square$ & $\square$ & $\square$ & $\square$ & $\square$ \\
\hline
\end{tabular}


Questionnaire \#

Respondent \#

Interviewer ID

\begin{tabular}{l|c|c|c|c|c|c|c} 
g.You focus on your core activities & $\square$ & $\square$ & $\square$ & $\square$ & $\square$ & $\square$ & $\square$ \\
\hline h.You have no definite service priorities & $\square$ & $\square$ & $\square$ & $\square$ & $\square$ & $\square$ & $\square$ \\
\hline $\begin{array}{l}\text { i. You change provision only when under pressure } \\
\text { from external agencies }\end{array}$ & $\square$ & $\square$ & $\square$ & $\square$ & $\square$ & $\square$ & $\square$ \\
\hline $\begin{array}{l}\text { j. You give little attention to new opportunities for } \\
\text { product delivery }\end{array}$ & $\square$ & $\square$ & $\square$ & $\square$ & $\square$ & $\square$ & $\square$ \\
\hline $\begin{array}{l}\text { k. You explore new opportunities when under } \\
\text { pressure from interest groups }\end{array}$ & $\square$ & $\square$ & $\square$ & $\square$ & $\square$ & $\square$ & $\square$ \\
\hline $\begin{array}{l}\text { I. You have no consistent response to external } \\
\text { pressure }\end{array}$ & $\square$ & $\square$ & $\square$ & $\square$ & $\square$ & $\square$ & $\square$
\end{tabular}

\section{Part Vl: Firm Performance}

Select all that apply

\begin{tabular}{l|c|c|c|c|c|c|c}
$\begin{array}{l}\text { 6.01 Which indicator do you use to see if you } \\
\text { have performed? Please rate your favored } \\
\text { indicator }\end{array}$ & $\begin{array}{c}\text { Highly } \\
\text { unfavorable }\end{array}$ & $\begin{array}{c}\text { Unfavor } \\
\text { able }\end{array}$ & Neutral & Favorable & $\begin{array}{c}\text { Highly } \\
\text { favorable }\end{array}$ & $\begin{array}{c}\text { Idon't } \\
\text { know }\end{array}$ & $\begin{array}{c}\text { Not } \\
\text { applicable }\end{array}$ \\
\hline a. Number of customers & $\square$ & $\square$ & $\square$ & $\square$ & $\square$ & $\square$ & $\square$ \\
\hline b. Full capacity of production & $\square$ & $\square$ & $\square$ & $\square$ & $\square$ & $\square$ & $\square$ \\
\hline c. Sales growth (number of product) & $\square$ & $\square$ & $\square$ & $\square$ & $\square$ & $\square$ & $\square$ \\
\hline d. Sales growth (revenue) & $\square$ & $\square$ & $\square$ & $\square$ & $\square$ & $\square$ & $\square$ \\
\hline e. Others _(please specify) & $\square$ & $\square$ & $\square$ & $\square$ & $\square$ & $\square$ & $\square$
\end{tabular}

6.02 Over the last 3 years, to what extent has the overall performance of the firm been achieved? It is achieved by_

1. [ ] 2.[ ] 3. 3 ] 30 4. [ ] 5. [ ]

$100 \% \quad$ Between 50 and $100 \% \quad$ Less than $50 \% \quad$ Very little achieved Not achieved at all

\begin{tabular}{l|c|c|c|c|c|c}
\hline $\begin{array}{l}\text { 6.03 Having in your mind your overall business } \\
\text { performance, what is your opinion on changes in sales } \\
\text { revenue, total expenses and number of employee? }\end{array}$ & Decrease & $\begin{array}{l}\text { A little } \\
\text { decrease }\end{array}$ & $\begin{array}{l}\text { Stay the } \\
\text { same }\end{array}$ & $\begin{array}{l}\text { A little } \\
\text { increase }\end{array}$ & Increase \\
\hline Sales revenue this year in 2013. & $\square$ & $\square$ & $\square$ & $\square$ & $\square$ \\
\hline Sales revenue last year in 2012. & $\square$ & $\square$ & $\square$ & $\square$ & $\square$ \\
\hline Sales revenue in 2011. & $\square$ & $\square$ & $\square$ & $\square$ & $\square$ \\
\hline Total expenses & $\square$ & $\square$ & $\square$ & $\square$ & $\square$ \\
\hline Total expenses this year in 2013 & $\square$ & $\square$ & $\square$ & $\square$ & $\square$ \\
\hline Total expenses last year in 2012 & $\square$ & $\square$ & $\square$ & $\square$ & $\square$ \\
\hline Total expenses in 2011 & $\square$ & $\square$ & $\square$ & $\square$ & $\square$ & $\square$ \\
\hline Number of employees & $\square$ & $\square$ \\
\hline Number of employees this year in 2013 & $\square$ & $\square$ & $\square$ & $\square$ & $\square$ \\
\hline Number of employees last year in 2012 & $\square$ & $\square$ & $\square$ & $\square$ & $\square$ \\
\hline Number of employees in 2011 & $\square$
\end{tabular}

Key:

Year $2013=1^{\text {st }}$ July $2012 \rightarrow 30^{\text {th }}$ June 2013

Year $2012=1^{\text {st }}$ July $2011 \rightarrow 30^{\text {th }}$ June 2012

Year $2011=1^{\text {st }}$ July $2010 \rightarrow 30^{\text {th }}$ June 2011 


\begin{tabular}{|c|c|c|c|c|c|c|c|}
\hline $\begin{array}{l}\text { 6.04 What is your opinion on future } \\
\text { performance of the firm? }\end{array}$ & $\begin{array}{l}\text { Strongly } \\
\text { disagree }\end{array}$ & Disagree & $\begin{array}{l}\text { Neither } \\
\text { agree nor } \\
\text { disagree }\end{array}$ & Agree & $\begin{array}{c}\text { Strongly } \\
\text { agree }\end{array}$ & $\begin{array}{l}\text { Idon't } \\
\text { know }\end{array}$ & N/A \\
\hline $\begin{array}{l}\text { a.Sales revenue will absolutely increase in the } \\
\text { next year }\end{array}$ & $\square$ & $\square$ & $\square$ & $\square$ & $\square$ & $\square$ & $\square$ \\
\hline $\begin{array}{l}\text { b. Total expenses will absolutely decrease in } \\
\text { the next year }\end{array}$ & $\square$ & $\square$ & $\square$ & $\square$ & $\square$ & $\square$ & $\square$ \\
\hline $\begin{array}{l}\text { c. The number of employees will increase in the } \\
\text { next year }\end{array}$ & $\square$ & $\square$ & $\square$ & $\square$ & $\square$ & $\square$ & $\square$ \\
\hline $\begin{array}{l}\text { d. New product varieties and brands will } \\
\text { increase in the next year }\end{array}$ & $\square$ & $\square$ & $\square$ & $\square$ & $\square$ & $\square$ & $\square$ \\
\hline $\begin{array}{l}6.05 \text { Which among the following is likely to } \\
\text { challenge your business? }\end{array}$ & $\begin{array}{l}\text { Most } \\
\text { unlikely }\end{array}$ & Unlikely & Neutral & Likely & Very likely & $\begin{array}{l}\text { I don't } \\
\text { know }\end{array}$ & $\begin{array}{c}\text { Not } \\
\text { applicable }\end{array}$ \\
\hline 1. Inflation & $\square$ & $\square$ & $\square$ & $\square$ & $\square$ & $\square$ & $\square$ \\
\hline 2. Taxation & $\bar{\square}$ & $\square$ & $\square$ & $\square$ & $\square$ & $\square$ & $\square$ \\
\hline 3. Decrease in product demand & $\square$ & $\square$ & $\square$ & $\square$ & $\square$ & $\square$ & $\square$ \\
\hline 4. High interest rates & $\square$ & $\square$ & $\square$ & $\square$ & $\square$ & $\square$ & $\square$ \\
\hline 5. Difficult Access to credit & $\square$ & $\square$ & $\square$ & $\square$ & $\square$ & $\square$ & $\square$ \\
\hline 6. Corruption & $\square$ & $\square$ & $\square$ & $\square$ & $\square$ & $\square$ & $\square$ \\
\hline $\begin{array}{l}\text { 7. Personnel (recruiting, training and } \\
\text { maintaining) }\end{array}$ & $\square$ & $\square$ & $\square$ & $\square$ & $\square$ & $\square$ & $\square$ \\
\hline 8. Excessive legal controls & $\bar{\square}$ & $\square$ & $\bar{\square}$ & $\square$ & $\bar{\square}$ & $\square$ & $\bar{\square}$ \\
\hline $\begin{array}{l}\text { 9. Bureaucracy in government administrative } \\
\text { regulations }\end{array}$ & $\square$ & $\square$ & $\square$ & $\square$ & $\square$ & $\square$ & $\square$ \\
\hline 10. Competition from food importers & $\square$ & $\square$ & $\square$ & $\square$ & $\square$ & $\square$ & $\square$ \\
\hline 11. Lack of business support services & $\bar{\square}$ & $\square$ & $\bar{\square}$ & $\square$ & $\square$ & $\square$ & $\bar{\square}$ \\
\hline 12. Availability of harvest from farmers & $\square$ & $\square$ & $\square$ & $\square$ & $\square$ & $\square$ & $\square$ \\
\hline 13. Others & $\bar{\square}$ & $\square$ & $\square$ & $\bar{\square}$ & $\bar{\square}$ & $\bar{\square}$ & $\bar{\square}$ \\
\hline
\end{tabular}

6.06 What recommendations do you have for better firm management? 
C. Georg-August-Universität Göttingen

GRK 1666 GlobalFood

Transformation of Global Agri-Food Systems

Idara ya Uchumi-Kilimo na Maendeleo Vijijini

Utafiti wa Kampuni za Biashara-Kilimo Tanzania 2013

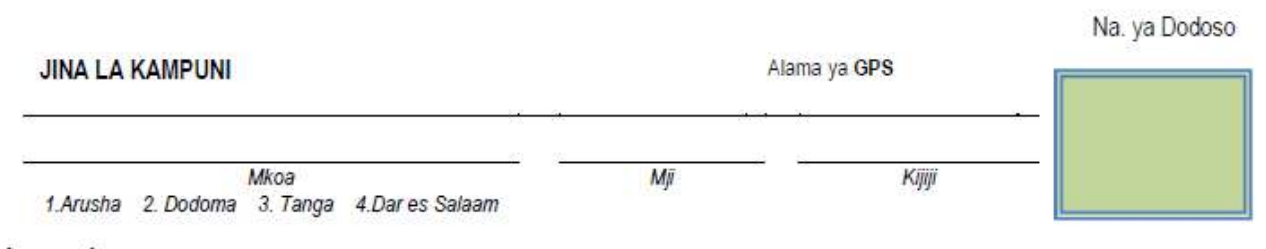

Anwani ya kampuni:

Phone:

\begin{tabular}{l|l|l}
\multicolumn{2}{l|}{ MSAILI } & $\begin{array}{l}\text { Na. ya } \\
\text { kitambulisho. }\end{array}$ \\
\hline \multicolumn{2}{c}{ Jina na Sahihi } & \\
\hline Mara ya 1 & Tarehe na Muda wa Usaili: \\
\hline Mara ya 2 & Tarehe na Muda wa Usaili: \\
\hline
\end{tabular}

Vidokezo

\begin{tabular}{l|l|l}
\multicolumn{2}{c|}{ TAREHE YA KUINGIZA DATA } & $\begin{array}{l}\text { Na. ya } \\
\text { kitambulisho. }\end{array}$ \\
\cline { 1 - 2 } $\begin{array}{l}\text { Jina na Sahihi } \\
\begin{array}{l}\text { Tarehe ya kuingiza } \\
\text { data }\end{array}\end{array}$ \\
$\begin{array}{l}\text { Tarehe ya kukagua } \\
\text { data }\end{array}$ & (lkiwa sahihi weka alama ya $\sqrt{ })$ \\
\hline $\begin{array}{l}\text { Hadhi/Kiwango } \\
\text { (Ikiwa sahihi weka alama ya } \sqrt{ } \text { ) }\end{array}$ \\
\hline
\end{tabular}

\begin{tabular}{l|l|l}
\multicolumn{2}{c|}{ MTAFITI } & $\begin{array}{l}\text { Na. ya } \\
\text { Kitambulisho }\end{array}$ \\
\hline \multicolumn{2}{c}{ Jina na Tarehe } & \\
\hline Tarehe ya Kukagua & \\
\hline Tarehe ya Kukagua & \\
\hline Hadhi/Kiwango & Zinaridhisha [ ] Haziridhishi [ ] \\
\hline
\end{tabular}




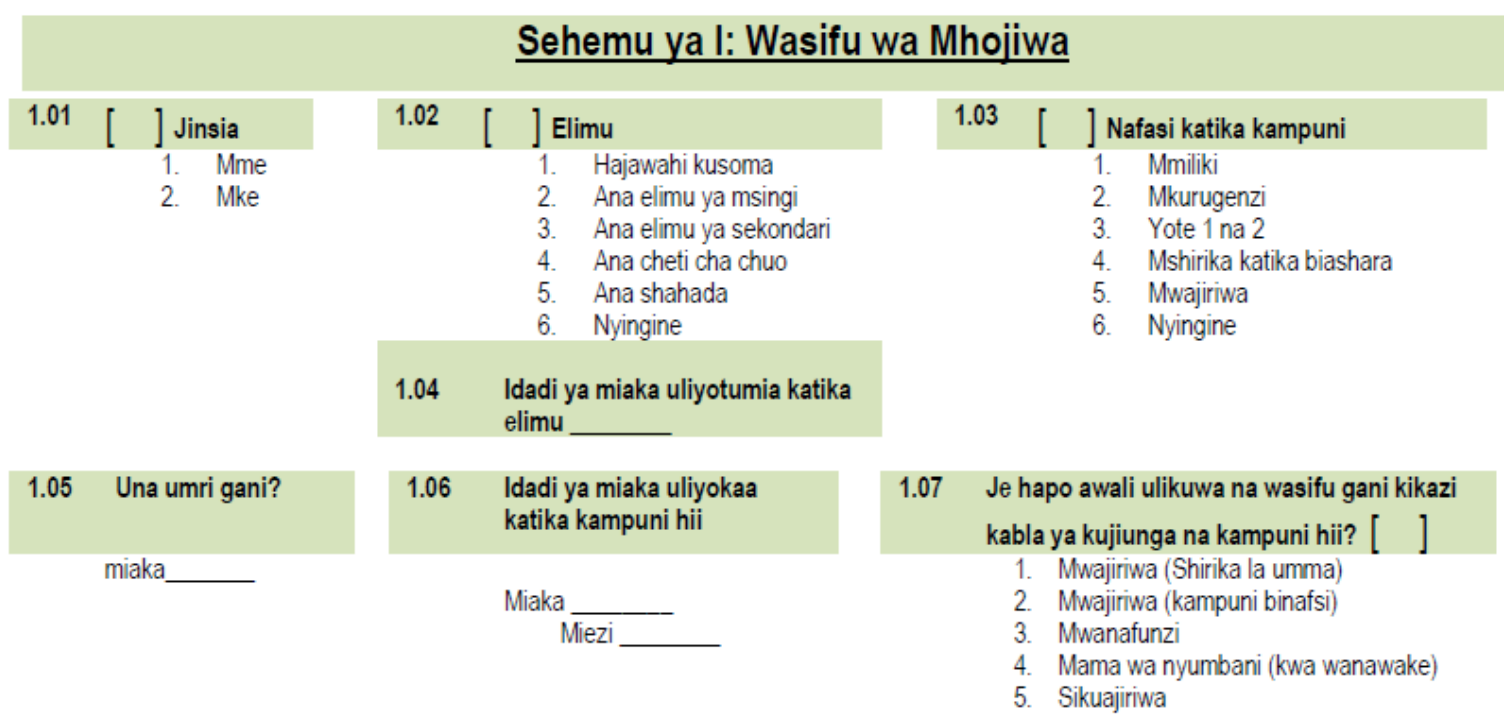

1.08 Je unazungumza lugha ngapi? Asili/Kienyeji Kigeni

Chagua;

1. Kiswahili[ ] 2. Kiingereza [ ] 3. Nyingine [ ] 4. Nyingine [ ]

\begin{tabular}{|c|c|c|c|c|c|c|c|}
\hline \multicolumn{3}{|c|}{1.09 Umilisi wa lugha za Kigeni } & Sio vizuri sana & Si vizuri & Katikati & Vizuri & Vizuri sana \\
\hline 1. & \multicolumn{2}{|l|}{ Ninaweza kuandika Kiingereza. } & $\square$ & $\square$ & $\square$ & $\square$ & $\square$ \\
\hline 2. & \multicolumn{2}{|l|}{ Ninaweza kuelewa Kiingereza. } & $\square$ & $\square$ & $\square$ & $\square$ & $\square$ \\
\hline 3. & \multicolumn{2}{|l|}{ Ninaweza kusoma Kiingereza. } & $\square$ & $\square$ & $\square$ & $\square$ & $\square$ \\
\hline 4. & \multicolumn{2}{|l|}{ Ninaweza kuzungumza Kiingereza. } & $\square$ & $\square$ & $\square$ & $\square$ & $\square$ \\
\hline \multicolumn{2}{|c|}{$\begin{array}{l}1.10 \text { Kwa kipimo cha kuanzia } 1 \text { mpaka } 5 \text {, } \\
\text { jipime uwezo wako wa kiutaalamu katika } \\
\text { mambo yafuatayo (linganisha na waajiriwa } \\
\text { wote katika kampuni hii) }\end{array}$} & $\begin{array}{c}\text { Sifahamu } \\
\text { kabisa } \\
1\end{array}$ & $\begin{array}{l}\text { Nahitaii } \\
\text { marekebisho } \\
2\end{array}$ & $\begin{array}{l}\text { Wastani } \\
3\end{array}$ & $\begin{array}{l}\text { Vizuri } \\
4\end{array}$ & $\begin{array}{l}\text { Vizuri sana } \\
5\end{array}$ & Haipo \\
\hline 1. & Utunzaji mahesabu na uhasibu & $\square$ & $\square$ & $\square$ & $\square$ & $\square$ & $\square$ \\
\hline 2. & Kusimamia waajiriwa & $\square$ & $\square$ & $\square$ & $\square$ & $\square$ & $\square$ \\
\hline 3. & Mbinu za masoko & $\square$ & $\square$ & $\square$ & $\square$ & $\square$ & $\square$ \\
\hline 4. & Utawala wa fedha & $\square$ & $\square$ & $\square$ & $\square$ & $\square$ & $\square$ \\
\hline 5. & $\begin{array}{l}\text { Kuhesabu mali na kutunza } \\
\text { kumbukumbu }\end{array}$ & $\square$ & $\square$ & $\square$ & $\square$ & $\square$ & $\square$ \\
\hline 6. & Sifa ya chakula na usalama & $\square$ & $\square$ & $\square$ & $\square$ & $\square$ & $\square$ \\
\hline 7. & Huduma kwa wateja & $\square$ & $\square$ & $\square$ & $\square$ & $\square$ & $\square$ \\
\hline 8. & Utangazaji mazao & $\square$ & $\square$ & $\square$ & $\square$ & $\square$ & $\square$ \\
\hline 9. & Usindikaji chakula & $\square$ & $\square$ & $\square$ & $\square$ & $\square$ & $\square$ \\
\hline 10. & Nyingine & $\square$ & $\square$ & $\square$ & $\square$ & $\square$ & $\square$ \\
\hline 11. & Nyingine & $\square$ & $\square$ & $\square$ & $\square$ & $\square$ & $\square$ \\
\hline
\end{tabular}

1.11 (kama mhojiwa sio mmiliki)

Je mwenye kampuni anashiriki katika uendeshaji wa kampuni kila siku?

Nolio=1 Hapana $=0$ 


\section{Sehemu ya Il: Sifa za Kampuni}

\subsection{Je kampuni iko wapi? [ ] \\ 1. Jiji \\ 2. $\mathrm{Mji}$ \\ 3. Kijjini}

\subsection{Umri wa shughuli za kampuni: Miaka Miezi \\ 2.4 \\ [ ] Je ni kampuni ya familia?}

1. Ndio
2.3 [ ] Sifa za kampuni

1. Binafsi

2. Ubia/ushirika

3. Umma

4. Nyinginezo

\section{Idadi ya wafanyakazi}

2.06 Waajiriwa wa kudumu

2.07 Waajiriwa wa mikataba

\subsection{8}

\section{Aina}

1. Wawekezaji wa nje

0. Hamna wawekezaji wa nje
2.5 Idadi ya wamiliki wengine

\subsection{Biashara ya nje [ ]}

1. Huuza nje ya nchi

0. Haiuzi nje ya nchi

2.10 Kiasi cha mtaji mkuu shilingi

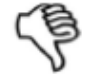

\begin{tabular}{l|l|l|l|l}
2.11 Sentensi & $\begin{array}{c}\text { Sikubaliani } \\
\text { kabisa }\end{array}$ & Sikubali & $\begin{array}{c}\text { Sikubali wala } \\
\text { sikatai }\end{array}$ & $\begin{array}{c}\text { Nakubali } \\
\text { kabisa }\end{array}$ \\
\hline a. Una taswira ya muundo wa kampuni & & & & \\
\hline b. Umeweka wazi mgawanyo wa kazi kwa wafanyakazi & & & & \\
\hline c. Umeandika mpango wa biashara unaoeleweka & & & & \\
\hline d. Una uwezo wa kufuata taratibu zote za biashara kisheria & & & &
\end{tabular}

\begin{tabular}{|c|c|c|c|c|c|}
\hline 2.12 & Jina la bidhaa & 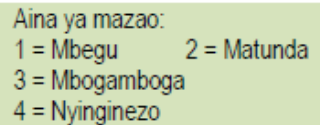 & $\begin{array}{l}1=\text { Za kuharibika } \\
\text { haraka } \\
2=\text { Si za kuharibika } \\
\text { haraka }\end{array}$ & $\begin{array}{l}\text { Malighafi napata kutoka } \\
1=\text { Wakulima wa ndani } \\
2=\text { Nje ya nchi }\end{array}$ & Maoni \\
\hline & Bidhaa ya 1 & & [ ] & [ ] & \\
\hline & Bidhaa ya 2 & & {$\left[\begin{array}{ll}\text { ] } \\
{[}\end{array}\right.$} & [ ] & \\
\hline & Bidhaa ya 3 & & {$\left[\begin{array}{ll}\text { ] } \\
\text { ] }\end{array}\right.$} & [ ] & \\
\hline & Bidhaa ya 4 & & [ ] & [ ] & \\
\hline & Bidhaa ya 5 & & {$\left[\begin{array}{ll}\text { ] } \\
\end{array}\right.$} & [ ] & \\
\hline & Bidhaa ya 6 & & {$\left[\begin{array}{ll}1 & 0\end{array}\right.$} & {$\left[\begin{array}{ll}\text { l } \\
\text { ] }\end{array}\right.$} & \\
\hline
\end{tabular}




\section{Sehemu ya Ill: Maliasili na Mazingira ya Kampuni}

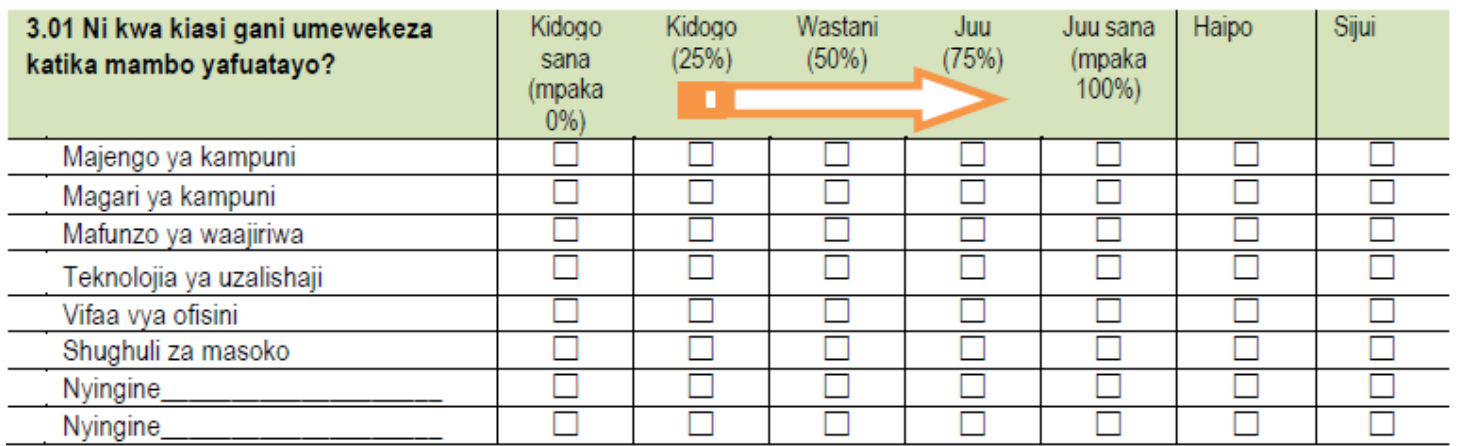

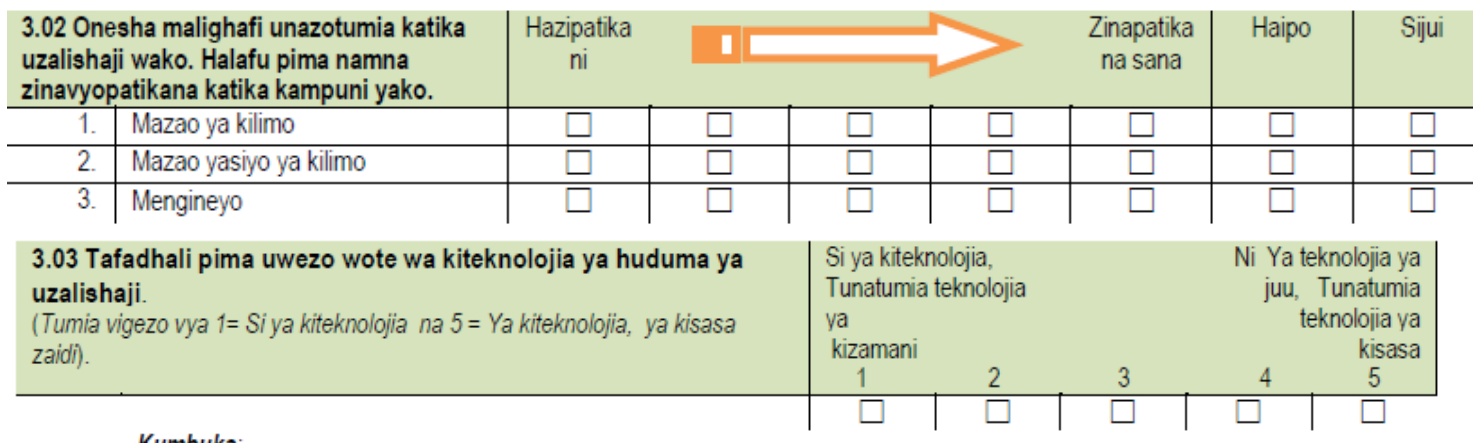

Kumbuka

Pale teknolojia moja inapitwa na teknolojia mpya, ya kisasa na bora, basi teknolojia ya awall inakuwa imepitwa na wakati, hii inategemea modeli ya teknolojia. Teknolojia ya kisasa hutumia umeme kidogo, ni nyepesi kubeba, ni bora katika uzalishail, na hudumu.

\begin{tabular}{l|l|c|c|c|c|c}
$\begin{array}{l}3.04 \\
\text { Onesha uwezo wa matumizi ya } \\
\text { mitandao na kompyuta katika shughuli } \\
\text { za usindikaji chakula }\end{array}$ & Kamwe & $\begin{array}{l}\text { Mara moja } \\
\text { kwa juma }\end{array}$ & $\begin{array}{l}\text { Mara mbili } \\
\text { kwa juma }\end{array}$ \\
\hline 1. & Simu & $\square$ & $\square$ & $\square$ & $\square$ & $\square$ \\
\hline 2. & Kompyuta ya mezani & $\square$ & $\square$ & $\square$ \\
\hline 3. & Kompyuta ya kiganjani (laptop) & $\square$ & $\square$ & $\square$ & $\square$ \\
\hline 4. & Mashine ya kutolea nakala & $\square$ & $\square$ & $\square$ & $\square$ & $\square$ \\
\hline 5. & Mtandao (barua pepe) & $\square$ & $\square$ & $\square$ & $\square$ & $\square$ \\
\hline 6. & Skena & $\square$ & $\square$ & $\square$ & $\square$ & $\square$ \\
\hline 7. & Nukunishi/Nukushi (fax) & $\square$ & $\square$ & $\square$ & $\square$ & $\square$ \\
\hline 8. & Nyinginezo & $\square$ & $\square$ & $\square$ & $\square$ & $\square$ \\
\hline 9. & Nyinginezo & $\square$ & $\square$ & $\square$ & $\square$ & $\square$ \\
\hline
\end{tabular}

\begin{tabular}{l|c|c|c|c|c|c|c}
$\begin{array}{l}3.05 \\
\text { zifuatazo unazipata kirahisi? }\end{array}$ & $\begin{array}{l}\text { Hazipatikani } \\
\text { kabisa }\end{array}$ & \multicolumn{2}{c}{$\begin{array}{l}\text { Zinapatik- } \\
\text { ana sana }\end{array}$} & Haipo \\
\hline Sehemu za kupata malighafi & $\square$ & $\square$ & $\square$ & $\square$ & $\square$ & $\square$ \\
\hline Mabadiliko ya bei za bidhaa & $\square$ & $\square$ & $\square$ & $\square$ & $\square$ & $\square$ \\
\hline Masoko & $\square$ & $\square$ & $\square$ & $\square$ & $\square$ & $\square$ & $\square$ \\
$\square$
\end{tabular}


Dodoso

Mhojiwa \#

ID Na. ya Msaili

Habari za wateja

Wakati muafaka wa kuuza

Taarifa za washindani wa kibiashara

Viwango vya kodi

Washirika kibiashara

Nyinginezo

\begin{tabular}{l|l|l|l}
$\square$ & $\square$ & $\square$ & $\square$ \\
$\square$ & $\square$ & $\square$ & $\square$ \\
$\square$ & $\square$ & $\square$ & $\square$ \\
$\square$ & $\square$ & $\square$ & $\square$
\end{tabular}

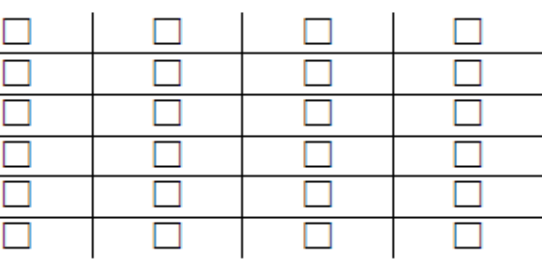

\begin{tabular}{|c|c|c|c|c|c|c|c|}
\hline $\begin{array}{l}3.06 \text { Pima utaalamu wa kampuni yako } \\
\text { katika vigezo vifuatavyo }\end{array}$ & $\begin{array}{c}\text { Hajaisome } \\
\text { a kabisa } \\
1\end{array}$ & 2 & 3 & 4 & $\begin{array}{l}\text { Amesomea } \\
\text { sana } \\
\quad 5\end{array}$ & Haipo & Sijui \\
\hline Utunzaji mahesabu & $\square$ & $\square$ & $\square$ & $\square$ & $\square$ & $\square$ & $\square$ \\
\hline Utawala wa watu & $\square$ & $\square$ & $\square$ & $\square$ & $\square$ & $\square$ & $\square$ \\
\hline Mbinu za masoko & $\square$ & $\square$ & $\square$ & $\square$ & $\square$ & $\square$ & $\square$ \\
\hline Utawala wa fedha & $\square$ & $\square$ & $\square$ & $\square$ & $\square$ & $\square$ & $\square$ \\
\hline Utunzaji kumbukumbu & $\square$ & $\square$ & $\square$ & $\square$ & $\square$ & $\square$ & $\square$ \\
\hline Uhasibu & $\square$ & $\square$ & $\square$ & $\square$ & $\square$ & $\square$ & $\square$ \\
\hline Huduma kwa wateja & $\square$ & $\square$ & $\square$ & $\square$ & $\square$ & $\square$ & $\square$ \\
\hline Uwasilishaji wa mazao & $\square$ & $\square$ & $\bar{\square}$ & $\bar{\square}$ & $\bar{\square}$ & $\bar{\square}$ & $\square$ \\
\hline Usindikaji chakula & $\square$ & $\square$ & $\square$ & $\square$ & $\square$ & $\square$ & $\square$ \\
\hline Nyingine & $\square$ & $\square$ & $\square$ & $\square$ & $\square$ & $\square$ & $\square$ \\
\hline Nyingine & $\square$ & $\square$ & $\square$ & $\square$ & $\square$ & $\square$ & $\square$ \\
\hline
\end{tabular}

3.07 Nini vyanzo vyako vikuu viwili vya pesa kwa ajili ya uwekezaji wa muda mrefu?

$\left.\begin{array}{lll}\hline \text { Pesa binafsi } & =1 & {[} \\ \text { Mkopo wa muda mfupi (chini ya mwaka 1) } & =2 & {[} \\ \text { Mkopo wa muda mrefu (zaidi ya mwaka 1) } & =3 & {[} \\ \text { Pesa za ubia } & =4 & {[} \\ \text { Nyinginezo, elezea: } & =5 & {[}\end{array}\right]$

\begin{tabular}{|c|c|c|c|c|c|c|c|}
\hline $\begin{array}{l}3.08 \text { Wakati wa mchakato wa kuom } \\
\text { mkopo wa kupanua shughuli za } \\
\text { kampuni yako na kuwekeza zaidi, } \\
\text { unazionaje huduma zifuatazo? }\end{array}$ & $\begin{array}{c}\text { Sio nzuri } \\
\text { kabisa }\end{array}$ & Sio nzuri & Wastani & Nzuri & Nzuri sana & Sijui & Haipo \\
\hline Mkopeshaji binafsi & $\square$ & $\square$ & $\square$ & $\square$ & $\square$ & $\square$ & $\square$ \\
\hline Benki ya binafsi (vijijinii) & $\square$ & $\square$ & $\square$ & $\square$ & $\square$ & $\square$ & $\square$ \\
\hline Benki ya binafsi (mjinni) & $\square$ & $\square$ & $\square$ & $\square$ & $\square$ & $\square$ & $\square$ \\
\hline Benki ya ushirika & $\square$ & $\square$ & $\square$ & $\square$ & $\square$ & $\square$ & $\square$ \\
\hline Fedha za jumuiya & $\square$ & $\square$ & $\square$ & $\square$ & $\square$ & $\square$ & $\square$ \\
\hline Benki ya serikali & $\square$ & $\square$ & $\square$ & $\square$ & $\square$ & $\square$ & $\square$ \\
\hline Kampuni binafsi & $\square$ & $\square$ & $\square$ & $\square$ & $\square$ & $\square$ & $\square$ \\
\hline Nyingine_ & $\square$ & $\square$ & $\square$ & $\square$ & $\square$ & $\square$ & $\square$ \\
\hline Nyingine_ & $\square$ & $\square$ & $\square$ & $\square$ & $\square$ & $\square$ & $\square$ \\
\hline
\end{tabular}




\section{Sehemu ya IV: Mazingira ya Nje}

\begin{tabular}{|c|c|c|c|c|c|c|c|}
\hline $\begin{array}{l}4.01 \text { Katika kiwango cha } 1 \text { mpaka } 5 \text {, } \\
\text { tafadhali pima kiwango cha upatikanaji wa } \\
\text { malighafi utakazohizaji katika uzalishaji }\end{array}$ & $\begin{array}{l}\text { Hazipatik- } \\
\text { ani }\end{array}$ & \multicolumn{3}{|l|}{ 口 } & $\begin{array}{l}\text { Zinapatik- } \\
\text { ana sana }\end{array}$ & Haipo & Sijui \\
\hline 1. Mazao yatokanayo na kilimo & $\square$ & $\square$ & $\square$ & $\square$ & $\square$ & $\square$ & $\square$ \\
\hline \begin{tabular}{l|l}
2. & Mazao yasiyotokana na kilimo \\
\end{tabular} & $\square$ & $\square$ & $\square$ & $\square$ & $\square$ & $\square$ & $\square$ \\
\hline \begin{tabular}{l|l}
3. & Mengineyo
\end{tabular} & $\square$ & $\square$ & $\square$ & $\square$ & $\square$ & $\square$ & $\square$ \\
\hline $\begin{array}{l}4.02 \text { Je ni sehemu gani kati ya hizi zifuatazo } \\
\text { ndio muhimu katika mauzo ya kampuni } \\
\text { yako? }\end{array}$ & $\begin{array}{l}\text { Sio } \\
\text { muhimu } \\
\text { kabisa }\end{array}$ & $\begin{array}{c}\text { Sio } \\
\text { muhimu }\end{array}$ & Katikati & Muhimu & $\begin{array}{l}\text { Muhimu } \\
\text { sana }\end{array}$ & Sijui & Haihusiki \\
\hline a. Maeneo ya jirani & $\square$ & $\square$ & $\square$ & $\square$ & $\square$ & $\square$ & $\square$ \\
\hline b. Soko asilia la chakula & $\square$ & $\square$ & $\square$ & $\square$ & $\square$ & $\square$ & $\square$ \\
\hline c. Maduka madogomadogo & $\square$ & $\square$ & $\square$ & $\square$ & $\square$ & $\square$ & $\square$ \\
\hline d. Maduka makubwa (supamaketi) & $\square$ & $\square$ & $\square$ & $\square$ & $\square$ & $\square$ & $\square$ \\
\hline e. Masoko ya jumla (maduka ya jumla) & $\square$ & $\square$ & $\square$ & $\square$ & $\square$ & $\square$ & $\square$ \\
\hline f. Hoteli, shule na makazini & $\square$ & $\square$ & $\square$ & $\square$ & $\square$ & $\square$ & $\square$ \\
\hline g. Masoko ya kimataifa & $\square$ & $\square$ & $\square$ & $\square$ & $\square$ & $\square$ & $\square$ \\
\hline h. Mengineyo_ & $\square$ & $\square$ & $\square$ & $\square$ & $\square$ & $\square$ & $\square$ \\
\hline
\end{tabular}

\begin{tabular}{|c|c|c|c|c|c|c|c|}
\hline $\begin{array}{l}4.03 \text { Je unajipimaje uwezo wako wa ushindani } \\
\text { kwa kuangalia; }\end{array}$ & $\begin{array}{l}\text { Hafifu } \\
\text { sana }\end{array}$ & Hafifu & Wastani & Imara & $\begin{array}{c}\text { Imara } \\
\text { sana }\end{array}$ & Sijui & Haipo \\
\hline Makampuni ya ndani & 1 & 2 & 3 & 4 & 5 & 0 & \\
\hline Makampuni ya nje katika masoko ya ndani & 1 & 2 & 3 & 4 & 5 & 0 & \\
\hline Makampuni yanayoagiza bidhaa toka nje & 1 & 2 & 3 & 4 & 5 & 0 & \\
\hline Mengineyo & 1 & 2 & 3 & 4 & 5 & 0 & \\
\hline
\end{tabular}

\begin{tabular}{|c|c|c|c|c|c|c|}
\hline $\begin{array}{l}4.04 \text { Tafadhali onyesha mtazamo wako jinsi } \\
\text { kampuni yako inavyopata huduma za } \\
\text { miundombinu ya umma na huduma nyingine } \\
\text { mbalimbali }\end{array}$ & $\begin{array}{l}\text { Nakataa } \\
\text { katukatu }\end{array}$ & Nakataa & $\begin{array}{c}\text { Sikubali } \\
\text { wala sikatai }\end{array}$ & Nakubali & $\begin{array}{c}\text { Nakubali } \\
\text { kabisa }\end{array}$ & Haipo \\
\hline Kampuni ipo katika barabara kuu ya mkoa & $\square$ & $\square$ & $\square$ & $\square$ & $\square$ & $\square$ \\
\hline Kampuni ipo katikati ya mji & $\square$ & $\square$ & $\square$ & $\square$ & $\square$ & $\square$ \\
\hline Kuna huduma za simu & $\square$ & $\square$ & $\square$ & $\square$ & $\square$ & $\square$ \\
\hline Napata huduma za umeme & $\square$ & $\square$ & $\square$ & $\square$ & $\square$ & $\square$ \\
\hline Napata huduma za maji & $\square$ & $\square$ & $\square$ & $\square$ & $\square$ & $\square$ \\
\hline Kuna huduma za kudumu za simu & $\square$ & $\square$ & $\square$ & $\square$ & $\square$ & $\square$ \\
\hline Napata huduma za umeme usiokatikakatika & $\square$ & $\square$ & $\square$ & $\square$ & $\square$ & $\square$ \\
\hline Napata huduma za maji yasiyokatikakatika & $\square$ & $\square$ & $\square$ & $\square$ & $\square$ & $\square$ \\
\hline
\end{tabular}

\begin{tabular}{|c|c|c|c|}
\hline & Hali ya mazingira & & \\
\hline 4.05 & $\begin{array}{l}\text { Umbali kutoka sehemu ya uzalishaji mpaka } \\
\text { barabarani }\end{array}$ & 4.06 Muda wa kusafiri & Masaa ___ Dakika \\
\hline 4.07 & $\begin{array}{l}\text { Umbali kutoka sehemu ya uzalishaji mpaka soko la } \\
\text { karibu }\end{array}$ & $\mathrm{km}$ & \\
\hline 4.08 & Kukatikakatika kwa umeme & Inatokea mara ngapi kwa mwezi_ & \\
\hline 4.09 & Vurugu katika jamii (mtaani) & Zinatokea mara ngapi kwa mwezi & \\
\hline
\end{tabular}


Dodoso

\begin{tabular}{|c|c|c|}
\hline 4.10 & Uwizi kutoka katika biashara & Inatokea mara ngapi kwa mwaka __ \\
\hline 4.11 & Uwizi katika jamii (mtaani) & Inatokea mara ngapi kwa mwaka \\
\hline 4.12 & $\begin{array}{l}\text { Mabadiliko ya sheria za biashara serikalini } \\
1=\text { Kamwe } \\
2=\text { Mara moja ndani ya miaka mitano } \\
\text { 3= Mara moja kwa mwaka } \\
4=\text { Mara mbili kwa mwaka } \\
5=\text { Kila mwezi }\end{array}$ & Inatokea mara ngapi kwa mwaka_ \\
\hline 4.13 & $\begin{array}{l}\text { Je kuna utaratibu gani wa kupata leseni ya biashara? } \\
\text { 1= Sio Mzuri kabisa } \\
\text { 2= Sio Mzuri } \\
\text { 3= Katikati } \\
\text { 4= Mzuri } \\
\text { 5= Mzuri sana }\end{array}$ & $\begin{array}{l}\text { Idadi ya siku } \\
\text { (Kutoka siku ya kuomba mpaka kupata leseni) }\end{array}$ \\
\hline
\end{tabular}

\section{Sehemu ya V: Mbinu na Mipango ya Usimamizi}

Sentensi zifuatazo ni maelezo juu ya shughuli mbalimbali ambazo makampuni huzifanya ili kutekeleza mipango yao. Tumia kipimo cha 1 mpaka 6; ikiwa 1 ni 'kukataa katukatu' na 6 ni 'kukubali kabisa' 0, kama hujui na NA kama 'haipo'

\begin{tabular}{l|c|c|c|c|c|c} 
5.01 Shughuli za kuyachunguza mazingira & $\begin{array}{c}\text { Nakataa } \\
\text { katakata }\end{array}$ & Nakataa & $\begin{array}{c}\text { Sikubali } \\
\text { wlaa } \\
\text { sikatai }\end{array}$ & Nakubali & $\begin{array}{c}\text { Nakubali } \\
\text { kabisa }\end{array}$ & $\begin{array}{c}\text { Sijui } \\
\text { Haipo }\end{array}$ \\
\hline $\begin{array}{l}\text { Umeorodhesha uwezo na mapungufu ya } \\
\text { kampuni }\end{array}$ & $\square$ & $\square$ & $\square$ & $\square$ & $\square$ & $\square$ \\
\hline $\begin{array}{l}\text { Una taarifa juu ya fursa nzuri kwa ajili ya } \\
\text { maendeleo ya kampuni }\end{array}$ & $\square$ & $\square$ & $\square$ & $\square$ & $\square$ & $\square$ \\
\hline $\begin{array}{l}\text { Unawaelewa wateja wako na mahitaji yao ya } \\
\text { huduma }\end{array}$ & $\square$ & $\square$ & $\square$ & $\square$ & $\square$ \\
$\square$
\end{tabular}

\begin{tabular}{l|c|c|c|c|c|c} 
5.02 Mipango na shughuli zake & $\begin{array}{c}\text { Nakataa } \\
\text { katakata }\end{array}$ & Nakataa & $\begin{array}{c}\text { Sikubali } \\
\text { wiaa } \\
\text { sikatai }\end{array}$ & Nakubali & $\begin{array}{c}\text { Nakubali } \\
\text { kabisa }\end{array}$ & Saijui \\
\hline $\begin{array}{l}\text { Umeshaona jinsi kampuni yako itakavyokuwa } \\
\text { kuanzia sasa mpaka miaka 5 hadi 10 ijayo }\end{array}$ & $\square$ & $\square$ & $\square$ & $\square$ & $\square$ & $\square$ \\
\hline Umeorodhesha malengo ya kampuni & $\square$ & $\square$ & $\square$ & $\square$ & $\square$ & $\square$ \\
\hline $\begin{array}{l}\text { Malengo ya kampuni hurekebishwa mara kwa } \\
\text { mara }\end{array}$ & $\square$ & $\square$ & $\square$ & $\square$ & $\square$ & $\square$ \\
\hline $\begin{array}{l}\text { Malengo ya kampuni yanajulikana kwa kila } \\
\text { mwajiriwa }\end{array}$ & $\square$ & $\square$ & $\square$ & $\square$ & $\square$ & $\square$ \\
\hline
\end{tabular}

\begin{tabular}{|c|c|c|c|c|c|c|c|}
\hline 5.03 Utekelezaji & $\begin{array}{l}\text { Nakataa } \\
\text { katakata }\end{array}$ & Nakataa & $\begin{array}{l}\text { Sikubali } \\
\text { wlaa } \\
\text { sikatai }\end{array}$ & Nakubali & $\begin{array}{c}\text { Nakubali } \\
\text { kabisa }\end{array}$ & Sijui & Haipo \\
\hline $\begin{array}{l}\text { Umetengeneza vitabu vinayoonesha namna ya } \\
\text { undeshaji }\end{array}$ & $\square$ & $\square$ & $\square$ & $\square$ & $\square$ & $\square$ & $\square$ \\
\hline Umewasilisha taratibu za kazi & $\square$ & $\square$ & $\square$ & $\square$ & $\square$ & $\square$ & $\square$ \\
\hline
\end{tabular}


Dodoso \#

Mhojiwa \#

ID Na. ya Msaili

Taratibu zinaeleweka na kila mfanyakaz

Kampuni inaweza kufadhili utekelezaji wa

mipango yake

Wafanyakazi wana ari ya kutekeleza mipango

ya kampuni

Kuna wafanyakazi wa kutosha kutekeleza

mipango ya kampuni

Kuna uwezo wa kutosha wa kutekeleza

mipango hii

\begin{tabular}{l|c|c|c|c|c|c|c} 
zizi & $\square$ & $\square$ & $\square$ & $\square$ & $\square$ & $\square$ & $\square$ \\
\hline zango & $\square$ & $\square$ & $\square$ & $\square$ & $\square$ & $\square$ & $\square$ \\
\hline & $\square$ & $\square$ & $\square$ & $\square$ & $\square$ & $\square$ & $\square$ \\
\hline za & $\square$ & $\square$ & $\square$ & $\square$ & $\square$ & $\square$ & $\square$
\end{tabular}

\begin{tabular}{l|c|c|c|c|c|c}
$\mathbf{5 . 0 4}$ Tadhimini na udhibiti & $\begin{array}{c}\text { Nakataa } \\
\text { katakata }\end{array}$ & Nakataa & $\begin{array}{c}\text { Sikubali } \\
\text { wlaa } \\
\text { sikatai }\end{array}$ & Nakubali & $\begin{array}{c}\text { Nakubali } \\
\text { kabisa }\end{array}$ & $\begin{array}{c}\text { Sijui } \\
\text { Unalinganisha shughuli zako na mipango yako } \\
\text { mara kwa mara }\end{array}$ \\
\hline Unatengeneza mipango mbadala & $\square$ & $\square$ & $\square$ & $\square$ & $\square$ & $\square$ \\
\hline $\begin{array}{l}\text { Unalinganisha mipango yako na ile ya } \\
\text { washindani wako }\end{array}$ & $\square$ & $\square$ & $\square$ & $\square$ & $\square$ & $\square$ \\
$\square$
\end{tabular}

\begin{tabular}{|c|c|c|c|c|c|c|c|}
\hline \multirow{2}{*}{\multicolumn{3}{|c|}{$\begin{array}{l}\text { 5.05 Je unafahamu nyenzo za kibiashara } \\
\text { zifuatazo? } \\
\text { (1=Ndio } 2=\text { Hapana) }\end{array}$}} & \multicolumn{5}{|c|}{5.06 Je unazitumia mara ngapi? } \\
\hline & & & \multirow{2}{*}{ Kamwe } & \multirow{2}{*}{$\begin{array}{c}\text { Mara chache } \\
\square\end{array}$} & \multirow{2}{*}{$\begin{array}{c}\begin{array}{c}\text { Mara moja } \\
\text { moja }\end{array} \\
\square\end{array}$} & \multirow{2}{*}{ Mara nyingi } & \multirow{2}{*}{$\begin{array}{c}\text { Wakati wote } \\
\square\end{array}$} \\
\hline a & Urari (Uwiano wa mahesabu) & & & & & & \\
\hline$b$ & Akaunti ya faida na hasara & [ ] & $\square$ & $\square$ & $\square$ & $\square$ & $\square$ \\
\hline & $\begin{array}{l}\text { Mapato ya hela (Mtiririko wa } \\
\text { mapato ya hela) }\end{array}$ & [ ] & $\square$ & $\square$ & $\square$ & $\square$ & $\square$ \\
\hline & $\begin{array}{l}\text { Maazimia ya mwelekeo wa } \\
\text { mauzo }\end{array}$ & {$[$ ] } & $\square$ & $\square$ & $\square$ & $\square$ & $\square$ \\
\hline & Uchanganuzi wa maslahi & [ ] & $\square$ & $\square$ & $\square$ & $\square$ & $\square$ \\
\hline & Tathmini ya utendaji & [ ] & $\square$ & $\square$ & $\square$ & $\square$ & $\square$ \\
\hline 9 & Uchambuzi wa vihatarishi & [ ] & $\square$ & $\square$ & $\square$ & $\square$ & $\square$ \\
\hline & Tathmini ya thamani ya sasa & [ ] & $\square$ & $\square$ & $\square$ & $\square$ & $\square$ \\
\hline & Chemshabongo & [ ] & $\square$ & $\square$ & $\square$ & $\square$ & $\square$ \\
\hline & $\begin{array}{l}\text { Uchambuzi wa uwezo, } \\
\text { mapungufu, fursa na vihatarishi } \\
\text { vya kampuni }\end{array}$ & [ ] & $\square$ & $\square$ & $\square$ & $\square$ & $\square$ \\
\hline
\end{tabular}

\begin{tabular}{|c|c|c|c|c|c|c|c|}
\hline $\begin{array}{l}5.06 \text { Kwa kiasi gani unakubali anaau kukataa kauli } \\
\text { zifuatazo; }\end{array}$ & $\begin{array}{l}\text { Nakataa } \\
\text { katakata }\end{array}$ & Nakataa & $\begin{array}{l}\text { Sikubali } \\
\text { wala } \\
\text { sikatai }\end{array}$ & Nakubali & $\begin{array}{c}\text { Nakubali } \\
\text { kabisa }\end{array}$ & Sijui & Haipo \\
\hline a. Unaelezea vipaumbele vya huduma yako & $\square$ & $\square$ & $\square$ & $\square$ & $\square$ & $\square$ & $\square$ \\
\hline $\begin{array}{l}\text { b. Unajitahidi kuhakikisha unakuwa wa kwanza kutoa } \\
\text { huduma mpya }\end{array}$ & $\square$ & $\square$ & $\square$ & $\square$ & $\square$ & $\square$ & $\square$ \\
\hline c. Kutafuta fursa mpya ni sehemu kubwa ya mikakati yako & $\square$ & $\square$ & $\bar{\square}$ & $\bar{\square}$ & $\bar{\square}$ & $\square$ & $\square$ \\
\hline $\begin{array}{l}\text { d. Unabadili malengo mara kwa mara wakati wa masoko } \\
\text { mapya }\end{array}$ & $\square$ & $\square$ & $\square$ & $\square$ & $\square$ & $\square$ & $\square$ \\
\hline e. Unajitahidi kusimamia vipaumbele imara & $\square$ & $\square$ & $\square$ & $\square$ & $\square$ & $\square$ & $\square$ \\
\hline f. Huduma husika hutilia mkazo ufanisi katika utoaji & $\square$ & $\square$ & $\square$ & $\square$ & $\square$ & $\square$ & $\square$ \\
\hline
\end{tabular}


Dodoso

Mhojiwa \#

ID Na. ya Msaili

huduma

g. Unasimamia shughuli zako kuu

$\mathrm{h}$. Huna vipaumbele katika shughuli

i. Unabadili huduma kunapokuwa na shinikizo kutoka kwa mawakala wa nje

j. Unazipa uzito mdogo fursa mpya katika kutoa huduma

k. Unatafuta fursa mpya unapopata changamoto kutoka

kwa makundi shiriki

I. Huna majawabu rasmi kwa mashinikizo ya nje

\section{Sehemu ya Vl: Ufanisi wa Kampuni}

Chagua majibu yote yanayofaa

\begin{tabular}{l|c|c|c|c|c|c}
$\begin{array}{l}\text { 6.01 Ni vigezo gani unatumia kupima kama } \\
\text { umefanikiwa? Tafadali pima vigezo vyako }\end{array}$ & $\begin{array}{c}\text { Haifai } \\
\text { kabisa }\end{array}$ & Haifai & Katikati & Inafaa & Inafaa zaidi & Sijui \\
\hline a. Idadi ya wateja & $\square$ & $\square$ & $\square$ & $\square$ & $\square$ & $\square$ \\
\hline b. Uzalishaji wa hali ya juu & $\square$ & $\square$ & $\square$ & $\square$ & $\square$ & $\square$ \\
\hline c. Kukua kwa mauzo (idadi ya bidhaa) & $\square$ & $\square$ & $\square$ & $\square$ & $\square$ & $\square$ \\
\hline d. Kukua kwa mauzo (mapato) & $\square$ \\
\hline e. Nyingine _(elezea tafadhali) & $\square$ & $\square$ & $\square$ & $\square$ & $\square$ & $\square$ \\
$\square$
\end{tabular}

6.02 Kwa miaka 3 iliyopita, kwa kiasi gani kampuni hii imefanikiwa? Lengo limetimizwa kwa
1. [ ]
2.[ ]
3.[ ]
4. [ ]
5. [ ]
$100 \%$
Kati ya 50 na $100 \%$
Chini ya $50 \%$
Mafanikio kidogo sana
Mafanikio hamna

\begin{tabular}{l|c|c|c|c|c|c}
\hline $\begin{array}{l}\text { 6.03 Ukizingatia utendaji wa kampuni yako kwa ujumla, nini } \\
\text { maoni yako juu ya madadiliko ya mapato ya mauzo, } \\
\text { matumizi kwa ujumla, na idadi ya waajiriwa/wafanyakazi? } \\
\text { (Kipimo cha 1= Kupungua hadi 5 = Kuongezeka) }\end{array}$ & Pungua & $\begin{array}{l}\text { Pungua } \\
\text { kidogo }\end{array}$ & Hajjabadilika & $\begin{array}{l}\text { Imeongezeka } \\
\text { kidogo }\end{array}$ \\
\hline Mapato ya mauzo mwaka huu wa 2013. & $\square$ & $\square$ & $\square$ & $\square$ & $\square$ \\
\hline Mapato ya mauzo mwaka uliopita wa 2012. & $\square$ & $\square$ & $\square$ & $\square$ \\
\hline Mapato ya mauzo mwaka juzi wa 2011. & $\square$ & $\square$ & $\square$ & $\square$ & $\square$ & $\square$ \\
\hline Jumla ya matumizi & $\square$ & $\square$ & $\square$ & $\square$ \\
\hline Jumla ya matumizi mwaka huu wa 2013 & $\square$ & $\square$ & $\square$ & $\square$ & $\square$ \\
\hline Jumla ya matumizi mwaka uliopita wa 2012 & $\square$ & $\square$ & $\square$ & $\square$ \\
\hline Jumla ya matumizi mwaka juzi wa 2011 & $\square$ & $\square$ & $\square$ & $\square$ \\
\hline Idadi ya wafanyakazi & $\square$ & $\square$ & $\square$ \\
\hline Idadi ya wafanyakazi mwaka huu wa 2013 & $\square$ & $\square$ & $\square$ & $\square$ \\
\hline Idadi ya wafanyakazi mwaka uliopita wa 2012 & $\square$ & $\square$ & $\square$ & $\square$ \\
\hline Idadi ya wafanyakazi mwaka juzi wa 2011 & $\square$ & $\square$ \\
\hline
\end{tabular}

Ufunguo:

Mwaka 2013 = Kuanzia tarehe 1 Julai 2012 mpaka tarehe 30 Juni 2013

Mwaka 2012 = Kuanzia tarehe 1 Julai 2011 mpaka tarehe 30 Juni 2012

Mwaka 2011 = Kuanzia tarehe 1 Julai 2010 mpaka tarehe 30 Juni 2011 
Dodoso

\begin{tabular}{|c|c|c|c|c|c|c|c|}
\hline $\begin{array}{l}6.04 \text { Nini maoni yako juu ya utendaji } \\
\text { wa kampuni yako siku zijazo? }\end{array}$ & $\begin{array}{c}\text { Nakataa } \\
\text { kabisa }\end{array}$ & Nakataa & $\begin{array}{c}\text { Sikatai } \\
\text { wala } \\
\text { kukubali }\end{array}$ & Nakubali & $\begin{array}{l}\text { Nakubali } \\
\text { kabisa }\end{array}$ & Sijui & Haipo \\
\hline $\begin{array}{l}\text { a.Mapato ya mauzo yataongezeka } \\
\text { mwaka ujao }\end{array}$ & $\square$ & $\square$ & $\square$ & $\square$ & $\square$ & $\square$ & $\square$ \\
\hline $\begin{array}{l}\text { b. Matumizi yote yataongezeka mwaka } \\
\text { ujao }\end{array}$ & $\square$ & $\square$ & $\square$ & $\square$ & $\square$ & $\square$ & $\square$ \\
\hline $\begin{array}{l}\text { c. Idadi ya wafanyakazi itaongezeka } \\
\text { mwaka ujao }\end{array}$ & $\square$ & $\square$ & $\square$ & $\square$ & $\square$ & $\square$ & $\square$ \\
\hline $\begin{array}{l}\text { d. Aina ya bidhaa zitaongezeka mwaka } \\
\text { ujao }\end{array}$ & $\square$ & $\square$ & $\square$ & $\square$ & $\square$ & $\square$ & $\square$ \\
\hline
\end{tabular}

\begin{tabular}{|c|c|c|c|c|c|c|c|}
\hline $\begin{array}{l}6.05 \text { Yapi kati ya haya yanaweza kuwa } \\
\text { changamoto kwa kampuni yako? }\end{array}$ & $\begin{array}{c}\text { Nakataa } \\
\text { kabisa }\end{array}$ & Nakataa & $\begin{array}{l}\text { Sikatai wala } \\
\text { kukubali }\end{array}$ & Nakubali & $\begin{array}{l}\text { Nakubali } \\
\text { kabisa }\end{array}$ & Sijui & Haipo \\
\hline 1. Mfumuko wa bei & $\square$ & $\square$ & $\square$ & $\square$ & $\square$ & $\square$ & $\square$ \\
\hline 2. Kodi & $\square$ & $\square$ & $\square$ & $\square$ & $\square$ & $\square$ & $\square$ \\
\hline 3. Kupungua kwa mahitaji wa mazao & $\square$ & $\square$ & $\square$ & $\square$ & $\square$ & $\square$ & $\square$ \\
\hline 4. Riba kubwa & $\square$ & $\square$ & $\square$ & $\square$ & $\square$ & $\square$ & $\square$ \\
\hline 5. Ugumu wa kupata mikopo & $\square$ & $\square$ & $\square$ & $\square$ & $\square$ & $\square$ & $\square$ \\
\hline 6. Rushwa & $\square$ & $\bar{\square}$ & $\bar{\square}$ & $\bar{\square}$ & $\square$ & $\square$ & $\bar{\square}$ \\
\hline 7. Wafanyakazi (ajira, mafunzo, kudumu) & $\square$ & $\square$ & $\square$ & $\square$ & $\square$ & $\square$ & $\square$ \\
\hline 8. Uthibiti wa kisheria uliokithiri & $\square$ & $\square$ & $\square$ & $\square$ & $\square$ & $\square$ & $\square$ \\
\hline $\begin{array}{l}\text { 9. Urasimu katika taratibu za kiutawala } \\
\text { serikalini }\end{array}$ & $\square$ & $\square$ & $\square$ & $\square$ & $\square$ & $\square$ & $\square$ \\
\hline $\begin{array}{l}\text { 10. Ushindani toka kwa waingizaji chakula } \\
\text { toka nje }\end{array}$ & $\square$ & $\square$ & $\square$ & $\square$ & $\square$ & $\square$ & $\square$ \\
\hline 11. Ukosefu wa huduma saidizi za kibiashara & $\square$ & $\square$ & $\square$ & $\square$ & $\square$ & $\square$ & $\square$ \\
\hline $\begin{array}{l}\text { 12. Upatikanaji wa mavuno toka kwa } \\
\text { wakulima }\end{array}$ & $\square$ & $\square$ & $\square$ & $\square$ & $\square$ & $\square$ & $\square$ \\
\hline 13. Nyinginezo & $\square$ & $\square$ & $\square$ & $\square$ & $\square$ & $\square$ & $\square$ \\
\hline
\end{tabular}

6.06 Je una mapendekezo gani juu ya uendeshaji mzuri wa kampuni? 


\section{Curriculum Vitae}

Personal Details

\begin{tabular}{ll}
\hline Name: Theresia Dominic (Ms.) \\
Gender: Female \\
Date of Birth: $08^{\text {th }}$ April 1978 \\
Place of birth: Dar es salaam, Tanzania \\
Marital status: Married (two children - *2007, 2009) \\
Nationality: Tanzanian \\
Current address
\end{tabular}

Goslerstraße 13, PF 114, 37073 Göttingen · Germany

Academic education and scientific degrees

2012 - Present PhD Agricultural Sciences, Department of Agricultural Economics and Rural Development, University of Goettingen, Goettingen, Germany.

2002 - 2004 Masters in Business Administration, University of Dar es Salaam, Dar es Salaam, Tanzania.

1999-2002 BSc. Agricultural Economics and Agribusiness, Sokoine University of Agriculture, Morogoro, Tanzania

Conference papers and publications

Dominic, T. and Theuvsen, L. (2015) "The impact of external and internal factors on strategic management practices of agribusiness firms in Tanzania". GlobalFood Discussion Papers No. 55 http://www.unigoettingen.de/de/globalfood-discussion-paper-series/213486.html.

Dominic, T., Theuvsen, L., Mvungi, M. and Ufunguo, R. (2014) "HomeVeg Tanzania Managing a New Strategy Amidst GLIMPSE Challenges". International Food and Agribusiness Management Review, Vol. 17 Special Issue B.

Dominic, T. and Theuvsen, L. (2014), "Strategic management practices of agribusiness firms: The role of firm attributes and firm resources". Paper presented at the 2nd Global Food Symposium, Göttingen, Germany, 25-26 ${ }^{\text {th }}$ April 2014.

Research Interests

Human resources management, strategic management and organization development issues in agribusiness sector 


\section{Curriculum Vitae}

Grants and scholarships

DAAD/MoEVT, scholarship, Doctoral research position in Global Food

RTG, Germany, 2012-2015

Best Paper Award in the $10^{\text {th }}$ International Academy of African Business and Development (IAABD) Conference, May 19-23, 2009, Makerere University Business School - Kampala, Uganda

SIDA SAREC, Scholarship, MBA programme at the University of Dar es Salaam, Tanzania $(2002-2004)$

Work experience

2012 - Present Doctoral Researcher - Global Food RTG, Department of Agricultural Economics and Agribusiness, University of Goettingen, Goettingen, Germany

2005 - 2015 Assistant Lecturer, Department of General Management, University of Dar es Salaam, Tanzania

2002 - 2004 Tutorial Assistant, Department of General Management, University of Dar es Salaam, Tanzania

2002 - 2011 Associate, Entrepreneurship Centre, UDEC, Tanzania

2002 Intern, Credit Department - Head Office, CRDB Bank, Tanzania

Languages / Hobbies/ Other skills

Swahili (fluent), English (fluent) and German (intermediate)

Travelling, Cooking and Gardening

Data analysis with MS-Excel, SPSS, STATA; R and SmartPLS 2.0 M3

softwares

Referees

Prof. Dr. Ludwig Theuvsen, Georg-August Universität Göttingen, theuvsen@uni-goettingen.de

Dr. Severine Kessy, University of Dar es Salaam, severinesk@udsm.ac.tz Prof. Marcellina Chijoriga, University of Dar es Salaam, cellina@udbs.udsm.ac.tz

e-mail: tdominic@udbs.udsm.ac.tz, theresia.dominic@agr.uni-goettingen.de 